Dissertação apresentada ao Programa de Pós-Graduação em Design - PPGDesign, do Departamento de Artes \& Design, da PUC-Rio, como requisito parcial para obtenção do grau de Mestre em Design.

Orientador: Prof. Alberto Cipiniuk Coorientadora: Profa. Irina Aragão dos Santos 


\section{A PRÁTICA DO DESIGNE A SUA CONTRIBUIÇÃO PARA O CAMPO JOALHEIRO DO RIO DE JANEIRO}

Dissertação apresentada ao Programa de Pós-Graduação em Design como requisito parcial para obtenção do grau de Mestre em Design. Aprovada pela Comissão Examinadora abaixo assinada.

\section{Prof. Alberto Cipiniuk \\ Orientado \\ Departamento de Departamento de Artes \& Design - PUC-Rio \\ Profa. Aragão dos Santos \\ Coorientadora \\ Departamento de Departamento de Artes \& Design - PUC-Rio \\ Prof. Marco Antonio Magalhães Lima \\ Departamento de Departamento de Artes \& Design - PUC-Rio}

Profa. Maria de Lourdes de Oliveira Luz

Universidade Veiga de Almeida - UVA

Profa. Monah Winograd Coordenadora Setorial do Centro de Tecnologia e Ciências Humanas - PUC-Rio 
Todos os direitos reservados. É proibida a reprodução total ou parcial do trabalho sem autorização da universidade, da autora e do orientador.

\section{Ana Paula Valladares Feijó}

Especialista em Design de Moda pelo SENAI CETIQT (2015) e Bacharel em Desenho Industrial com ênfase em Projeto de Produto pela Pontifícia Universidade Católica do Rio de Janeiro - PUC-Rio (1995). Com cursos de extensão em Ourivesaria pelo SENAI, possui experiência de mercado, trabalhando para empresas do campo joalheiro. No meio acadêmico, atuando desde 2007, como docente nas áreas de joalheria e moda dos cursos de graduação da Escola de Design da Universidade Veiga de Almeida - UVA. Convidada pela Escola de Joalheria do SENAI - RJ, em 2009 e 2010, participou como docente nos programas: Aprendizado Profissionalizante e Jovem Aprendiz. De 2010 a 2011 atuou também como coordenadora da Graduação Tecnológica em Design de Produto - Joias e, de 2011 a 2016, como coordenadora acadêmica do Curso Superior de Moda no campus Tijuca, ambos da Universidade Veiga de Almeida, onde atualmente faz parte do quadro de docentes de moda.

Ficha Catalográfica

Feijó, Ana Paula Valladares

A prática do design e a sua contribuição para o campo joalheiro do Rio de Janeiro / Ana Paula Valladares Feijó; orientador: Alberto Cipiniuk; coorientadora: Irina Aragão dos Santos. -2017.

152 f. : il. color. ; $30 \mathrm{~cm}$

Dissertação (mestrado)-Pontifícia Universidade Católica do Rio de Janeiro, Departamento de Artes e Design, 2017.

Inclui bibliografia

1. Artes e Design - Teses. 2. Joia. 3. Adornos pessoais. 4. Design. 5. Campo joalheiro. 6. Representação simbólica. I. Cipiniuk, Alberto. II. Santos, Irina Aragão dos. III. Pontifícia Universidade Católica do Rio de Janeiro. Departamento de Artes e Design. IV. Título. 


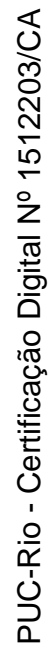

Em memória de meus queridos pais, Servilia e Luiz. 


\section{Agradecimento}

Minha gratidão é eterna aos meus pais, familiares, orientadores, professores, amigos e todos aqueles que cruzaram o meu caminho, que me ensinaram, que me escutaram e que me ajudaram a compreender um pouco mais sobre a vida e minhas escolhas pessoais e profissionais. 


\section{Resumo}

Feijó, Ana Paula Valladares; Cipiniuk, Alberto; Santos, Irina Aragão dos. A prática do design e a sua contribuição para o campo joalheiro do Rio de Janeiro. Rio de Janeiro, 2017. 152p. Dissertação de Mestrado - Departamento de Artes \& Design, Pontifícia Universidade Católica do Rio de Janeiro.

O campo joalheiro do Rio de Janeiro vivencia uma realidade impulsionada pela profissionalização de vários setores envolvidos principalmente com as etapas de criação, produção, comercialização e divulgação de novos produtos no mercado. Este cenário vem se configurando desde os anos 1990, quando o design do produto "joia" passa a ser trabalhado com a intenção de proporcionar novas experiências de consumo, reafirmando sobre seus usuários um encantamento pelo objeto que pode ir além do valor financeiro de sua matéria-prima, tão estimado pelas tradicionais gerações de joalheiros, e que ainda é tida como o argumento no 1 na criação de uma joia. Os cursos superiores, tecnólogos e de aprimoramento no setor, em conjunto com as novas tecnologias fabris, também trouxeram oportunidades para o campo e hoje dividem espaço com as técnicas artesanais de produção de joias. Estas, ainda muito utilizadas, resgatam as origens históricas desse objeto, que é trabalhado pelos designers sob uma nova leitura. Esta pesquisa apresenta uma breve reflexão sobre a importância da prática do design e sua atual contribuição para o campo presente no estado do Rio de Janeiro.

\section{Palavras-chaves} simbólica.

Joia; adornos pessoais; design; campo joalheiro; representação 


\section{Abstract}

Feijó, Ana Paula Valladares; Cipiniuk, Alberto (advisor); Santos, Irina Aragão dos (co-advisor). The practice of design and its contribution to the jewelry field in Rio de Janeiro. Rio de Janeiro, 2017. 152p. Dissertação de Mestrado - Departamento de Artes \& Design, Pontifícia Universidade Católica do Rio de Janeiro.

The jewelry field in Rio de Janeiro has showed a reality driven by the professionalization of several sectors, committed mainly with the steps of creation, production, commercialization and marketing of new products. This scenery has been outlined since the 1990's, when the design of the product "jewelry" started to be worked out with the intention of offer new consumer experiences, confirming on its wearers an enchantment by the object beyond the financial value of its raw material, so appreciated by the traditional generations of jewelers, and which still is considered the argument number one for the creation of jewelry. Undergraduate courses offered by universities, technical courses and any other formation to improve professionals of this sector, together with new technologies for the textile industry, have also brought opportunities for the field, and today they share this space with the artisanal techniques for the production of jewelry. Still quite used, they bring back the historical origins of this object, which has been revisited by the designers. This research presents a brief reflection about the importance of the design and its current contribution to the field in the Rio de Janeiro state.

\section{Keywords}

Jewelry; personal adornment; design; jewelry field; symbolic representation. 


\section{Sumário}

1. Introdução

2. O objeto de adorno pessoal 21

2.1. Definição e classificação de adorno pessoal 21

2.2. Processos de criação e sistemas de produção das joias 28

3. O campo joalheiro no Rio de Janeiro 44

3.1. Os objetos e o conceito construído no campo joalheiro do 49 Rio de Janeiro

3.2. As instituições de legitimação do campo joalheiro do

Rio de Janeiro

3.3. O ensino do design de joias no Rio de Janeiro

3.4. Os designers e suas relações com o cenário joalheiro carioca

4. O design para o campo da joalheria

4.1. A importância do design para o setor joalheiro no Rio de Janeiro

5. Conclusão

6. Referências bibliográficas

7. Glossário

8. Anexos 


\section{Lista de Figuras}

Figura 1 - llustração de colar em ouro branco com água-marinha 12

Figura 2 - Esquema das etapas do processo de fundição de um anel 36

Figura 3 - Exemplos de cravação 38

Figura 4 - Mapa do campo joalheiro do Rio de Janeiro 48

Figura 5 - Inspiração: Morro da Urca e o bondinho do Pão de Açúcar 51

Figura 6 - Inspiração: Topografia do Rio de Janeiro 52

Figura 7 - Inspiração: Cristo Redentor 53

Figura 8 - Inspiração: Lifestyle carioca 54

Figura 9 - Inspiração: Pobreza e miséria, o outro lado da cidade $\quad 55$

Figura 10 - Inspiração: Vida e obra de personalidades brasileiras $\quad 56$

Figura 11 - Inspiração: Maracanã 56

Figura 12 - Inspiração: Anéis que desempenham funções específicas 58

Figura 13 - Colares com cristal de quartzo transparente e ametista 123

\section{Lista de Tabelas}

Tabela 1 - Relação dos eventos comerciais que atendem ao campo joalheiro no Brasil 


\section{Introdução}

Há quase duas décadas atuando como designer de joias, principalmente na área de pesquisa e desenvolvimento de produtos, busco em meus "achismos" um breve caminho para discutir e, assim, tentar definir a atual situação em que se encontra o campo ${ }^{1}$ joalheiro do Rio de Janeiro e as contribuições do design, enquanto prática, na construção de um conceito para o desenvolvimento de produtos com características próprias, que representem esse mercado.

Achismo, no dicionário online Michaelis, é a "tendência em avaliar as situações segundo as próprias opiniões ou intenções, muitas vezes sem justificação"² e por isso, esclareço desde já que as situações aqui apresentadas são de total responsabilidade e interpretação da autora.

Inicio minhas colocações apresentando um simples fato, porém recorrente, que acontece quando me perguntam qual é a minha profissão e respondo: "designer de joias". Imediatamente é visível a mudança no semblante do interlocutor, que vem acompanhada de alguma expressão verbal popular de surpresa e comentários se referindo ao suposto glamour que envolve o ofício. Sendo assim, acredito que exista uma visão distorcida da profissão, além é claro, de que todo o profissional do campo joalheiro é muito bem remunerado justamente por isso. Podemos também citar os que acreditam que criar joias é um hobby para pessoas desocupadas ou "madames" ${ }^{4}$ com um poder aquisitivo elevado e que, por essa razão, podem investir nesse passatempo de luxo.

\footnotetext{
${ }^{1}$ Espaço social que, segundo Bourdieu, compreende desde as práticas específicas aos agentes de produção, recepção e circulação de um determinado grupo e que, neste caso, envolve o universo da joalheria. O campo, ao mesmo tempo em que é visto como um espaço de divulgação e reconhecimento entre seus agentes, também funcionado como um território de disputa e poder ao determinar a posição social ocupada por cada indivíduo do grupo.

${ }^{2}$ Michaelis. Disponível em: < http://michaelis.uol.com.br/busca?r=0\&f=0\&t=0\&palavra=achismo >. Acesso em: 30 de junho de 2015.

3 Hobby - palavra inglesa usada para designar uma atividade realizada por prazer, um passatempo.

${ }^{4}$ Madames - termo usado para designar as mulheres ricas e bem casadas, que não precisam trabalhar para se sustentar e vivem apenas para seus mimos.
} 
O designer que trabalha com o desenvolvimento do produto joia, além de realizar pesquisas envolvendo seu cliente ou a empresa na qual atuará, mapeando sua história e produtos existentes, deve identificar as oportunidades apresentadas pelo mercado, explorar as tendências de moda, definir o perfil de consumidor e analisar a sua concorrência. Deve ainda reunir uma vivência prática na manipulação de metal - basicamente ouro e/ou prata - além de outras matériasprimas utilizadas na construção das peças para então, idealizar um objeto passível de ser produzido e que atenda aos objetivos pré-definidos por um briefing ${ }^{5}$.

Em um momento de epifania, conhecido por insight ${ }^{6}$, usar o guardanapo na mesa de um bar como suporte para rabiscar, eventualmente poderá até acontecer, pois uma "boa ideia" não tem hora e nem lugar para se revelar. Representar a sua criação sobre uma superfície bidimensional, ou seja, desenhá-la em um papel, contudo, este procedimento é apenas uma das etapas dentro do processo de planejamento e desenvolvimento de uma peça, linha ou coleção de joias. Diferente do que muitos acreditam, o ato de desenhar bem não significa necessariamente criar um bom produto. Há técnicas para executar um belo desenho de joia, mesmo à mão livre e com o material apropriado, o volume das peças, o colorido e o brilho do metal, a opacidade ou a transparência e o reflexo das gemas são apresentados de forma realista (Figura 1), chamando atenção para o trabalho artístico de pintura e deixando a desejar no quesito criação, uma vez em que a peça é executada e o resultado final do produto não corresponde ao encantamento inicial gerado pela ilustração.

O ofício de produzir objetos de adorno pessoal sejam eles em metal, com pedras preciosas $^{7}$, fibras vegetais, conchas, ossos, presas e chifres de animais, cabelos ou qualquer outro material para adornar o corpo, bem como o uso para distinção e ostentação social, se faz presente desde os primórdios da história da humanidade. A memória inicial desses objetos é montada com base em

\footnotetext{
${ }^{5}$ Briefing - palavra inglesa que significa instruções. Em design, denominamos de briefing a lista de metas, características, exigências e limites no desenvolvimento de um projeto. É uma síntese de vários elementos básicos, vindos das mais diversas áreas que participam do processo de desenvolvimento de produtos e serviços. É uma síntese de vários elementos básicos, vindos das mais diversas áreas que participam do processo de desenvolvimento de produtos e serviços.

${ }^{6}$ Insight - palavra inglesa que significa "visão interior". Ele representa o momento exato em que o designer é surpreendido por uma ideia para a solução de um problema ou mesmo para a criação de um novo produto.

${ }^{7}$ Pedras preciosas ou gemas naturais são minerais encontrados na natureza e que atraem o homem por sua beleza, colorido e raridade. Definição apresentada pelo Manual Técnico de Gemas, desenvolvido pelo Instituto Brasileiro de Gemas e Metais, 2005, p. 11 Disponível em:< http://gemologia.ibgm.com.br/laboratorio/wp-content/uploads/2011/11/mtg_20051.pdf >. Acesso em: 25 de julho de 2015.
} 
suposições e nas análises das peças encontrados pelos paleontólogos e arqueólogos, passando depois, para a observação de relatos dos costumes e das transformações sociais apresentados em cada época.

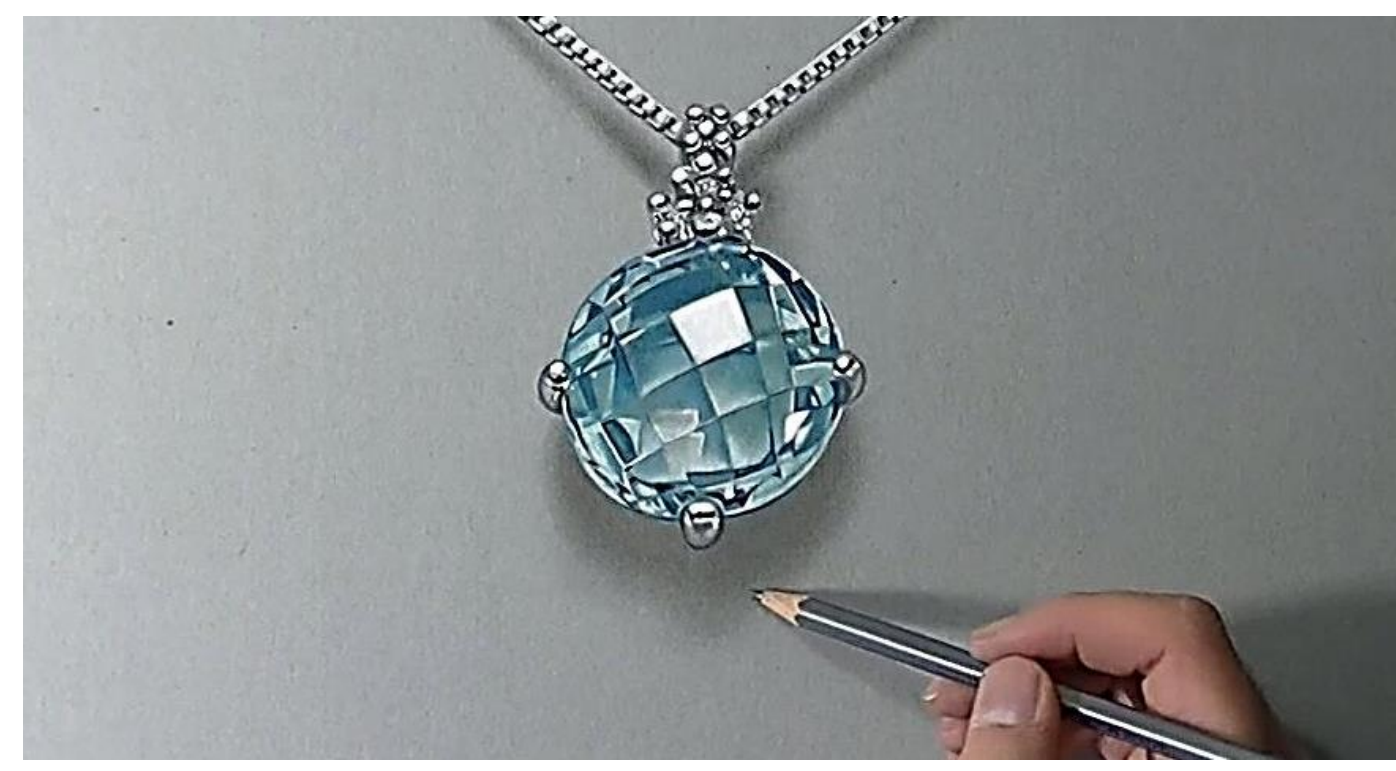

Figura 1 - llustração de colar em ouro branco com água-marinha.

llustrador e arquiteto Marcello Barenghi, 2013.

No Brasil, o ofício da ourivesaria só aportou no período da colonização e mesmo assim, os oficiais encarregados por essa função passaram por uma série de restrições em relação à produção de peças e a utilização metais preciosos ${ }^{8}$, como o ouro, que mesmo encontrado em abundância em território nacional era controlado pelo poder metropolitano. Conhecimento hereditário, algo aproximado à forma de ensino praticada pelos artesãos medievais, foi por muito tempo o meio pelo qual as técnicas do ofício da ourivesaria foram ensinadas no Brasil. Ainda menino, o jovem aprendiz começava suas práticas pelas tarefas mais simples, como o polimento de peças e, aos poucos, a medida da evolução de sua habilidade, seu pai, ou um parente próximo, o introduzia nas etapas mais complexas de construção de uma joia e na alquimia ${ }^{9}$ dos metais. $O$ tempo, aliado à repetição sistemática de técnicas, faz com que o novato na profissão alcance a perfeição, com velocidade de execução das peças, tornando-se assim,

\footnotetext{
${ }^{8}$ Metais precisos são elementos químicos metálicos que possuem um elevado valor econômico. Os mais conhecidos são o ouro e a prata que eram usados na cunhagem das moedas. A platina e o paládio, também nobres, são usados pela ourivesaria.

${ }^{9}$ Alquimia, neste caso, está sendo empregada no sentido de transmutação dos metais, ou seja, na preparação manual de diferentes ligas metálicas usadas na ourivesaria.
} 
um profissional requisitado pelo mercado, onde "tempo é dinheiro" e o desejo de um cliente deve ser prontamente atendido, pois uma peça parada no estoque representa capital de investimento estagnado. E nesse campo, ninguém quer sair perdendo.

O desconhecimento e, em muitos dos casos, a falta de comprometimento com questões que envolviam a ética na profissão, apresentavam a cópia como uma prática comum, diária e "necessária". Os profissionais que a realizavam não possuíam a vocação moderna da criação artística e sim a da reprodução e se valiam do anonimato para imitar peças de terceiros, sem temer a qualquer tipo de punição. Aliás, isso não era sequer pensado. Fazia parte do ofício.

A prática da cópia foi introduzida no campo com os primeiros ourives que vieram para o Brasil, aqui permaneceram e formaram seus ajudantes com as técnicas desenvolvidas em seus países de origem, e o ato de copiar uma peça era uma das formas de treinamento dada aos iniciantes. Este fato é comprovado através da análise das primeiras joias aqui confeccionadas, sendo elas, réplicas de peças trazidas de Portugal e de outras partes da Europa, de onde tudo era importado, sobretudo a moda, objetos de adorno pessoal ${ }^{10}$ e decorativos.

Nos dias de hoje, falar sobre as questões éticas que envolvem a profissão, principalmente em relação ao produto joia, é abordar um problema muito delicado. Conforme já citado, muitos profissionais mal intencionados se aproveitam do anonimato e da consequente impunidade perante as brechas das leis brasileiras, e claro, da falta de conhecimento dos designers sobre os processos e direitos adquiridos que envolvem os registros de suas criações.

Para se proteger uma joia o primeiro passo é o registro da sua criação. No Rio de Janeiro podemos contar com os serviços oferecidos pelo INPI - Instituto Nacional de Propriedade Industrial ${ }^{11}$ para o registro de Desenho Industrial, que envolve somente as peças passíveis de fabricação e os da EBA - Escola de Belas Artes / UFR ${ }^{12}$, para o registro de Direitos Autorais, que abraça a ideia da criação, sem a obrigatoriedade da execução. Com a modernização de suas operações, o INPI permite que o depositante, pessoa física ou jurídica, realize e

\footnotetext{
${ }^{10}$ Objetos de adorno pessoal - termo usado pela pesquisadora Irina Aragão dos Santos (2014) para definir o conjunto de peças decorativas que são usadas, tendo o corpo humano seu suporte principal. Como exemplo: colares, anéis, brincos, tiaras, broches e etc.

${ }^{11}$ INPI - Instituto Nacional de Propriedade Industrial. Disponível em: <http://www.inpi.gov.br/menuservicos/desenho/guia-basico-de-desenho-industrial>. Acesso em: 25 de julho de 2015.

${ }^{12}$ EBA / UFRJ - Escola de Belas Artes / Universidade Federal do Rio de Janeiro. Disponível em: <http://www.eba.ufrj.br/index.php/servicos/direitos-autorais>. Acesso em: 25 de julho de 2015.
} 
acompanhe todo o processo via web. ${ }^{13}$ Já na EBA o pedido poderá ser enviado por correspondência postal e tudo é arquivado manualmente, o que dificulta uma pesquisa de busca por similares de um produto. Ambos os registros necessitam do pagamento de uma taxa ${ }^{14}$ por meio eletrônico. No INPI o valor dessa taxa é de $R \$ 175,00$ (cento e setenta e cinco reais) e para: pessoa física, microempreendedor individual e algumas outras categorias protegidas por lei, aplicasse um desconto e o valor é reduzido para $\mathrm{R} \$ 70,00$ (setenta reais). $\mathrm{Na}$ EBA o depósito é de $R \$ 120,00$ (cento e vinte reais) por registro. $E$ quanto ao tempo de duração, o registro do INPI é válido por uma década, podendo ainda ser renovado por três períodos de cinco anos, totalizando vinte e cinco anos, e ao término deste período a patente cai em domínio público podendo ser reproduzida sem prévia autorização do titular. Sendo assim, algumas empresas registram simultaneamente no INPI e na EBA, garantindo um registro vitalício da criação/produto enquanto obra de arte, pois na EBA, o direito de exclusividade é vitalício ao seu autor e se estende por setenta anos aos herdeiros, após a sua morte.

Valores considerados altos para serem praticados por unidade de peça registrada e que em alguns casos não oferecem garantia de proteção total. Uma vez que bem conduzida a lei, por exemplo, não pune os responsáveis por cópias realizadas sem fins comerciais, ou seja, cópias para o próprio consumo, para uso pessoal são permitidas. De qualquer forma, todo designer ou criador de joias deveria registrar suas criações e reivindicar por seus direitos, toda vez em que se sentir lesado. Muitos desconhecem os procedimentos ou não os fazem por ser dispendioso e sem efeito concreto e punitivo. O registro das peças poderia contribuir para a formação de um grande banco de dados a ser consultado pelos interessados em lançar novos produtos, linhas ou coleções de joias. Neste banco, a busca prévia, realizada antes de se iniciar uma produção, poderia apontar as características similares entre produtos e sinalizar o que seria considerado plágio no mercado.

Plágio ou cópia não autorizada é crime previsto pelo art.184 do Código Penal Brasileiro e deveria ser levado mais a sério pelo campo joalheiro. Os órgãos competentes e as associações de classe que atendem ao campo joalheiro, como

\footnotetext{
${ }^{13}$ Web - palavra inglesa que significa teia ou rede. No mundo virtual ela é utilizada para designar a World Wide Web (WWW), a rede que conecta computadores ao redor do mundo.

${ }^{14}$ Valores consultados pela internet, em novembro de 2015.
} 
a AJORIO ${ }^{15}$, deveriam incentivar e fornecer algum tipo de suporte para que as empresas e os designers empreendedores investissem nos registros de suas criações.

As empresas familiares, que ainda representam uma boa fatia no campo joalheiro do Rio de Janeiro, mesmo possuindo uma equipe de designers para o desenvolvimento exclusivo de seus produtos, ainda são comandadas pelas preferências de seus acionistas. Neste caso, o trabalho do designer é facilmente contestado após a consulta de uma revista importada e repleta de novidades com os últimos lançamentos, principalmente de marcas famosas, como as francesas Cartier (1847), Chaumet (1780) e Van Cleef \& Arpels (1906), a italiana Bulgari (1884) e a americana Tiffany \& Co. (1837), consideradas, pelo tempo de fundação, as mais tradicionais joalherias ${ }^{16}$ do mundo. As imagens retiradas dessas publicações especializadas, e também dos catálogos de empresas do campo joalheiro, são fornecidas diretamente para produção, que segue a risca a orientação da mudança de alguns detalhes durante a reprodução e assim, ao final, não configura em um plágio e sim uma "inspiração".

Visitas às feiras internacionais de joias, BASEL WORLD ${ }^{17}$ na Suíça e VICENZA $\mathrm{ORO}^{18}$ na Itália, deveriam servir exclusivamente para pesquisas de tendências e não para um registro fotográfico ou a aquisição de peças a serem copiadas. Outro hábito também recorrente dentro das empresas que constituem o campo joalheiro do Rio de Janeiro. Já no Brasil, a feira mais tradicional e importante do campo é a FENINJER - Feira Nacional da Indústria de Joias, Relógios e Afins, em São Paulo. Esta feira é destinada exclusivamente aos empresários do ramo joalheiro, ficando o designer excluído da visitação, diferentemente do acontece nas feiras internacionais. Organizada pelo Instituto Brasileiro de Gemas e Metais Preciosos $^{19}$ - IBGM, a FENINJER acontece em duas edições anuais, fevereiro e agosto, e busca reunir em um único espaço os "expositores de joias em ouro e prata, gemas e artefatos de pedras, relógios e embalagens" ${ }^{20}$ para o lançamento de suas coleções.

\footnotetext{
${ }^{15}$ AJORIO - Associação dos Joalheiros e Relojoeiros do Estado do Rio.

${ }^{16}$ Ver bibliografia complementa: Cartier, Chaumet, Van Cleef \& Arpels, Bulgari e Tiffany \& Co.

${ }^{17}$ BASEL WORLD. Disponível em: < http://www.baselworld.com/>. Acesso em: 26 de outubro de 2015.

${ }^{18}$ VICENZA ORO. Disponível em: < http://www.vicenzaoro.com/en>. Acesso em: 26 de outubro de 2015.

${ }^{19}$ IBGM - Instituto Brasileiro de Gemas e Metais Preciosos.

${ }^{20}$ FENINJER. Disponível em: < http://novo.feninjer.com.br/sobre_feninjer>. Acesso em: 15 de outubro de 2016.
} 
Retomando ao assunto das instituições familiares, joalherias tradicionais, não poderíamos deixar de mencionar as empresas H.Stern ${ }^{21}$ (1954) e Amsterdam Sauer $^{22}$ (1941/1956), que fazem parte da história da joalheria no Brasil e foram fundadas por estrangeiros que desembarcam nas terras tupiniquins, em tempos de guerra, em busca de um futuro de paz. Na trajetória dessas empresas podemos destacar o encantamento e o trabalho desenvolvido por décadas para a valorização das gemas preciosas brasileiras, como por exemplo, a esmeralda, a água-marinha e o topázio imperial. Os senhores Hans Stern e Jules Sauer fizeram fama e fortuna com a comercialização de joias com pedras coloridas ${ }^{23} \mathrm{e}$ até hoje, suas empresas são referências para turistas estrangeiros em visita ao país.

Ao refletir sobre o fato da valorização dessas pedras coloridas brasileiras por estrangeiros, que há mais de meio século fundaram as mais tradicionais e importantes joalherias do país - H.Stern e Amsterdam Sauer - e comparar a uma suposta resistência que os brasileiros desenvolveram em relação ao uso dessas joias, habitualmente rotuladas como "joias de gringo" ${ }^{24}$, surgem vários caminhos a serem investigados e um deles, atravessa o Campo de Design e suas possíveis contribuições para esse objeto.

O meu interesse pelo universo da joalheria surgiu ao longo da graduação em Desenho Industrial - Projeto de Produto, na PUC-Rio (1991 a 1995). Durante esse período, sempre escutei que um designer seria capaz de projetar desde um alfinete até um avião. Porém, aquele que se propusesse a fazer de tudo um pouco, nunca seria "o melhor", ou seja, nunca se destacaria na multidão... E assim, percebi que deveria escolher um objeto industrial para concentrar todos os meus esforços e mostrar que a minha opção não era apenas um hobby e sim, uma profissão digna e reconhecida no mercado de trabalho.

Enquanto estudante, a primeira oportunidade de contato com o campo joalheiro se deu em uma pequena fábrica de bijuterias, que hoje não existe mais, mas que

\footnotetext{
${ }^{21}$ H.STERN. Time line. Disponível em: <http://www.hstern.com.br/institucional/hs_timeline.aspx/>. Acesso em: 30 de junho de 2015.

${ }^{22}$ A Lapidação Amsterdam foi fundada em 1941 e em 1956, a primeira loja da empresa no Rio de Janeiro. Disponível em: <http://amsterdamsauer.com.br/o-cacador-de-pedras-raras/> Acesso em: 30 de junho de 2015.

${ }^{23}$ Pedras coloridas ou gemas coloridas ou ainda pedras preciosas são termos usados para nomear um mineral, em estado bruto ou polido, que possui um colorido, que pode ser colecionável, e usado para confeccionar joias e objetos de decoração. Como exemplo, podemos citar: o verde da esmeralda; o roxo da ametista; o azul da água-marinha; o vermelho do rubi; azul escuro da safira, entre outras.

${ }_{24}$ Gringo - termo pejorativo usado para designar um estrangeiro.
} 
na época funcionava em um grande galpão, localizado na subida da comunidade do Jacaré, Zona Norte do Rio de Janeiro. Ao mesmo tempo em que fiquei encantada com a técnica e as possibilidades de reprodução das peças em larga escala, fique assustada com o despreparo dos funcionários que manuseavam o metal incandescente e a adaptação do maquinário para tal função. Ao invés de uma fundidora profissional, a fábrica possuía um tambor caseiro de máquina de lavar roupa, que fora modificado para funcionar com uma centrífuga, em que um molde de borracha era posicionado ao centro e a liga metálica* incandescente derramada manualmente em um orifício por um funcionário que, por sua vez, não usava nenhum tipo de equipamento de segurança ou mesmo, possuía noções de primeiros socorros para saber como proceder no caso de um acidente inesperado acontecer ao logo do processo. Foi em torno dessa situação, que o meu olhar de preocupação com o posto de trabalho, com a ergonomia e com a prevenção de acidentes falou mais alto, e mesmo tendo como função a pesquisa e o desenvolvimento de novas mercadorias, lembro que na época, sugeri algumas adequações em relação à segurança na produção.

Meu estágio nesta fábrica não foi apenas mais uma experiência para meu currículo. A partir dele, tudo o que transitava em torno do universo da joalheria passou a ser de meu interesse... Quando me formei, em 1995, mesmo trabalhado em outro campo do design, fui buscar a complementação da graduação em cursos específicos de desenho de joias, na AJORIO, de ourivesaria no Ateliê Mourão e técnico no SENAI, para praticar e entender melhor das técnicas de planejamento e confecção de pequenas peças em metal. Em março de 1997, mesmo com pouca experiência, tive a oportunidade de ser selecionada para trabalhar no departamento de design da Amsterdam Sauer Joalheiros, onde permaneci até setembro de 2006. Pude crescer com a empresa, principalmente em projetos relacionados com a imagem da instituição e a valorização do trabalho de design frente à pesquisa, desenvolvimento e criação de novas coleções.

Ao longo do caminho, já me deparei com várias "idas e vindas" do mercado, crises financeiras que desestabilizaram a economia e abalaram as empresas do campo. Além da alta joalheria, hoje trabalho com empresas de menor porte e desenvolvo um trabalho autoral. Vejo que o designer, ao mesmo tempo em que é apontado como a solução para todos os problemas dos produtos industriais, através do desenvolvimento de coleções originais e produtos inovadores, não é valorizado pela grande maioria das empresas do campo joalheiro, e que ainda 
Ihe atribuem a responsabilidade pelas cópias que invadem o mercado. O Sr. Ecio Moraes $(2009)^{25}$, diretor do IBGM, em poucas palavras definiu o meu pensamento ao declarar que o campo joalheiro trabalhou durante muito tempo de "forma amadora e descompromissada" e que, para superar as crises e a concorrência, deveria investir em inovação, matéria-prima, relacionamento com o cliente, novos canais de distribuição, entre outros.

$\mathrm{Na}$ busca por uma contribuição para o campo joalheiro, esta pesquisa identifica e discute sobre o perfil atual da prática do design como processo no desenvolvimento de objetos de adorno pessoal no Rio de Janeiro, e assim verifica os seguintes questionamentos: Como a prática do design está sendo empregada no campo joalheiro do Rio de janeiro? Qual a sua importância para o cenário carioca? Quem são os seus agentes e suas instâncias de legitimação?

Quanto à metodologia adotada, os estudos iniciaram com um levantamento bibliográfico do material existente e referente ao campo; seguido por um levantamento imagético de peças/objetos de adorno pessoal produzidas pelo campo; pesquisas em web sites relacionadas ao assunto; entrevistas com profissionais envolvidos com o campo joalheiro carioca; e uma experiência prática realizada em parceria com empresa do campo joalheiro atuante no Rio de Janeiro.

A pesquisa inicia com a definição e classificação disso que chamamos de joia, que segundo o senso comum, deve ser um objeto confeccionado em metal nobre, como o ouro amarelo e pedras preciosas, ou seja, em material raro e caro, usado pela joalheria tradicional. Dentro dos conceitos abordados pelos estudos científicos, englobando 08 artigos, 02 monografias, 05 dissertações, 04 teses e 03 publicações, pouco foi encontrado. A definição selecionada foi apresentada pela pesquisadora Irina Aragão dos Santos, coorientadora deste trabalho, em que o termo joia foi substituído por objeto de adorno pessoal. Para esta definição, o material confeccionado, seja ele ouro ou latão, fica em segundo plano, dando lugar aos atributos intangíveis associados ao produto, como por exemplo: emoção e prazer e a valorização de outros aspectos com a inovação e a moda. Ainda neste capítulo, são abordadas as definições de: folheado; bijuteria; biojoias e adornos de design, como forma de distinguir os objetos pertencentes a cada uma dessas categorias. Serão apresentados também os

\footnotetext{
${ }^{25}$ Declaração publicada no editorial do Catálogo Oficial da 49를 FENINJER, (2009, p.22).
} 
processos de criação e sistemas de produção oferecidos no campo joalheiro no estado Rio de Janeiro.

Um panorama sobre o campo joalheiro no Rio de Janeiro é exposto no segundo capítulo e com ele, uma investigação sobre a construção de um conceito para a criação de objetos - joias, folheados e bijuterias - que representem o nosso estado. São apresentadas as instâncias de produção e legitimação do campo, englobando as empresas, as associações de classe, institutos, feiras do setor e eventos de moda que promovem segmento, como também, as instituições de ensino, que desde o ano de 1999 aos dias atuais, trouxeram contribuições significativas para o campo. Complementar este capítulo, entrevistas foram realizadas como profissionais envolvidos na etapa de criação dos objetos designers de empresas, designers empreendedores e profissionais responsáveis pela equipe de criação/design das empresas - e após analisadas, incorporam o mapeamento com dados sobre a prática do design dentro do campo joalheiro.

O terceiro e último capítulo trás algumas definições para o entendimento do que é design e explora questões que envolvem a sua importância para a cadeia produtiva joalheira existente no estado do Rio de Janeiro. Relacionando com os dados levantados pelas entrevistas realizadas para o capítulo anterior, podemos observar que mesmo com a escassez da oferta de oportunidade de trabalho dentro das empresas, fabricantes e/ou comerciantes de joias, folheados e bijuterias, a baixa remuneração e a falta de uma conduta ética entre os profissionais envolvidos nos mais diversos segmentos do setor, é o combustível que vem despertando o interesse de novos designers pela profissionalização e pelo empreendedorismo do campo. Este capítulo finaliza a pesquisa com um estudo de caso, no qual duas estudantes do Curso Superior de Moda da Universidade Veiga de Almeida tiveram a oportunidade de vivenciar a prática do design, desenvolvendo e produzindo uma coleção de bijuterias com gemas coloridas brasileiras para uma empresa atuante no campo. Dividida em duas etapas - criação e produção - a experiência é relada passo a passo, analisando os fatos ocorridos. A etapa inicial que envolveu o desenvolvimento e a criação das peças foi considerada satisfatória pelo grupo em relação à quantidade de peças criadas, protótipos produzidos, visitação à feira do segmento, pesquisa e compra de insumos, tempo de duração do projeto e o valor recebido por peça. Já a etapa de produção não se mostrou tão vantajosa financeiramente para as designers. Concluíram que esta etapa poderia ser realizada por qualquer profissional, desde que apresente habilidades em manusear alicates e pequenas 
peças metálicas utilizadas na montagem de bijuterias, e atenção para seguir as instruções reproduzindo os protótipos desenvolvidos pelo grupo.

A partir da experiência realizada e do encantamento das estudantes de moda pela joalheria, pude perceber o quanto ainda sou conduzida pelo amor que tenho pela minha profissão e pelo sonho, mesmos nos dias mais difíceis, de ver um campo joalheiro próspero, de futuro esperançoso e construído com a contribuição do design. Agora, após a conclusão desta pesquisa, em que tive que mudar minha postura, com um olhar crítico e sobre outra perspectiva para 0 campo, vejo que ainda há muito a fazer, ou melhor, que o tempo passou, e desde a minha época de graduação, as coisas, as pessoas e os processos continuam como antes: desorganizadas, sem regras, sem responsabilidade e sem respeito ao trabalho do designer.

Os termos técnicos utilizados pela joalheria, destacados com um asterisco, e apresentados ao logo do texto, possuem sua descrição no glossário organizado no final do trabalho. 


\section{O objeto de adorno pessoal}

Os mistérios que permeiam a criação, a produção, os significados atribuídos e gerados pelo uso do objeto, então classificado como "adorno pessoal", encantam gerações e despertam os mais diversos interesses em relação ao seu estudo. Desde as tradições culturais às técnicas de produção e materiais empregados em sua fabricação, estes objetos podem ser encontrados expostos em museus, serem peças de colecionadores, ou mesmo objetos de desejo e que atendem as tendências de moda das sociedades modernas. Sendo assim, o adorno pessoal pode exercer diferentes funções de acordo com a cultura local, classe social, hábitos e religião de seus usuários e assim, se apresentar com um objeto de distinção social; um objeto que carrega sentidos místicos e religiosos; ou simplesmente, a de um artefato com a modesta pretensão de adornar o corpo, pelo simples prazer do belo.

Abordaremos a seguir algumas classificações e categorias de objetos nas quais os adornos pessoais podem ser agrupados, bem como seus processos de criação e produção praticados pelo campo joalheiro do Rio de Janeiro.

\section{1}

\section{Definição e classificação de adorno pessoal}

Os adornos pessoais independentemente de serem classificados como objetos históricos, religiosos ou mesmo enfeites para serem usados sobre o corpo, por exemplo, poderão ainda receber outra categorização e serem nomeados, dependendo principalmente do tipo de matéria-prima empregada em sua produção, como: joia; folheado; bijuteria; biojoias e adornos de design.

Eleita como a primeira desta relação de categorias, a joia foi escolhida por empregar materiais nobres e utilizados pela joalheria tradicional, como "o ouro, a platina e alguns metais de seu grupo (rutênio, ródio, paládio, ósmio e irídio), a 
prata e as pedras preciosas" (SANTOS, 2014, p. 24) na fabricação de seus objetos. Em alguns casos, a joia também pode ser analisada por um viés artificial como o apresentado na matéria Glamour em $\mathrm{Foco}^{26}$, publicada pela revista Vogue H.Stern. Nesta publicação a colunista e consultora de moda Costanza Pascolato $^{27}$ define joia como: "a cereja do bolo" no look contemporâneo. Joia, para o então mundo da moda, é o objeto que confere o diferencial na maneira de se vestir dos indivíduos e através dele, além da condição social, pode-se expressar, entre outras coisas, as preferências individuais, estilo de vida de seus usuários.

"Mais do que objetos raros, joias são símbolos. Estão ligadas a status, talento, prestígio, festa. Nada dá mais prazer que ganhar uma joia: nos sentimos valorizadas e importantes. Sem esquecer que são fantásticas para se selar um compromisso - mesmo aqueles que só são eternos enquanto duram."

"De posse de uma boa joia, descobre-se um universo em que prevalece o impecável, o primoroso. O requinte dessas peças faz com que fiquemos mais familiarizados com técnicas sofisticadas, o que nos anima a viver com elegância. E o refinamento sempre educa, ilumina." (PASCOLATO, 2006, p. 12.)

Requinte e sofisticação, prestígio, desejo e prazer... Objeto raro, a joia de luxo, por sua oferta e valor de mercado, desempenha dentre muitas funções, a de distinção social. Possuir um objeto de luxo dessa categoria eleva o seu consumidor à classe mais favorecida e dominante da sociedade, e a colunista ainda questiona: como viver sem elas? E assim, fica claro que o espaço social ao qual Pascolato pertence, ao definir uma joia, necessita desses objetos para se autopromover, como sinônimo de status e representação de seus diferentes capitais simbólicos: social, econômico ou financeiro e capital cultural. Afinal, além dos dois primeiros, o requinte da joia, que também é nomeado, que "sempre educa", demonstra aqui o valor de seu capital cultural.

O fato é que esse objeto não poderia ser um objeto qualquer e mesmo assim, a colunista faz uso da definição popular ao descrever o que seria essa joia. $O$ senso comum, que parte das vivências e observações do mundo ao nosso redor, classifica a joia como um objeto que deve ser necessariamente produzido por um material precioso e de valor financeiro elevado, ou seja, material raro e caro,

\footnotetext{
${ }^{26}$ Matéria publicada na Revista VOGUE H.STERN, 2016, p. 12. Costanza Pascolato defende a joia no dia a dia. Vogue H.Stern é parte integrante da Revista Vogue Brasil, no 334, 2006.

${ }^{27}$ Nome respeitado no universo da moda brasileira, Costanza Pascolato é colunista da revista Vogue, empresária e consultora de moda. Assinou coleções de joias para a H.Stern, empresa para qual também presta consultoria. Pascolato não é nomeada como designer e sim como a "pioneira na criação de uma coleção de joias para a H.Stern, em 1997". Revista Vogue Brasil, no 424, 2007, p. 45.
} 
utilizado principalmente pela joalheria de luxo ${ }^{28}$, que representa apenas um segmento dentro do campo joalheiro. Seguindo o pensamento de Bourdieu, essa visão foi construída a partir das necessidades de um grupo distinto, que ao elevar a joia para a categoria de "objeto raro e caro", deslocando-a assim de um lugar comum - joalheria - a um universo onde poucos teriam o privilégio de seu consumo - joalheria de luxo.

Ao longo dos tempos, através de um processo de inculcação, também batizado por Bourdieu como de violência simbólica ${ }^{29}$, fez com que o objeto da categoria joia, só merecesse ser chamado de joia, se produzido em metal nobre, como o ouro amarelo, por exemplo, e com a utilização de pedras preciosas, como: a safira, o rubi, a esmeralda e o diamante. Atualmente, esse "padrão" naturalizado como único existente, ainda é reconhecido pelas classes menos favorecidas da população. Essa joia, de material raro e caro, além de ser considerada eterna por seu material inicialmente indestrutível, também poderá ser vinculada a um valor sentimental ou simbólico, porém prevalecerá seu valor financeiro sempre que alguém fizer menção a ela, como no exemplo: "herdei o anel de ouro que foi da minha avó".

A definição abordada nos estudos científicos (artigos, monografias, dissertações, teses e publicações) para o conceito de joia, mesmo perante à tradição do objeto, é carente e ainda pouco explorada, exceto nos estudos desenvolvidas por Irina Aragão dos Santos. A pesquisadora e professora, que também é designer de joias, define o que é uma joia e ainda descreve com objetividade a diferença entre os termos: joia, folheado e bijuteria, que mesmo sendo usados com frequência pelo campo joalheiro, ainda provocam certa confusão na definição dos produtos, em relação ao emprego dos diversos tipos de materiais passíveis de produção desses objetos.

\footnotetext{
"Atualmente, o uso dos termos joia, folheado e bijuteria está vinculado ao tipo de material do qual são fabricados estes objetos e, consequentemente, ao seu valor de troca, de mercado. Portanto, joia significa um objeto de adorno pessoal, confeccionado de materiais que, por suas propriedades físicas e químicas que proporcionam fácil manipulação, raridade e circulação comercial, são convencionados como nobres e valiosos. De um modo geral, além do tipo, qualidade e quantidade destes materiais, o valor de uma peça também está

${ }^{28} \mathrm{Ou}$ joalherias tradicionais, conforme definição apresentada em nota de rodapé por Santos. "Considero como joalheria tradicional aquela que usa metais nobres e gemas na confecção de peças em formas figurativas ou estilizadas em composições florais, zoomórficas e geométricas" (SANTOS, 2014, p.24)

29 Termo utilizado por Bourdieu para explicar com regras e crenças, não contestadas, podem ser impostas a um grupo de indivíduos por agentes dominantes em um determinado campo.
} 
vinculado à sua forma (inovação e composição estética, e impacto visual), estilo, grife e excelência na fabricação. Chama-se folheado, o objeto de adorno pessoal, confeccionado de materiais e metais convencionados como não nobres que, posteriormente, são revestidos de metais nobres como o ródio, o ouro ou a prata por processo galvânico. O corpo destas peças - chamado de bruto, é confeccionado de metais não nobres, tais como latão, cobre, zamac e ligas de estanho. E chama-se bijuteria o objeto de adorno pessoal confeccionado de materiais não nobres e baratos. Na montagem de bijuterias são utilizados materiais variados: de pedras naturais baratas às sintéticas, contas e miçangas de vidro, plásticos, madeiras, tecidos, metais e outros componentes industrializados, ou produzidos artesanalmente". (SANTOS, 2014, p. 16)

Segundo Santos, além da nobreza e da quantidade dos materiais empregados e já mencionados como sendo o primeiro quesito diferenciador para os objetos pertencentes à categoria das joias, podemos verificar também que a forma, o conceito empregado na sua criação, a qualidade final de sua apresentação, como a chancela da joalheria de origem, são fatores que também contribuem para o somatório de características que definem estes objetos.

Diferente das joias, porém tentando imitá-las em sua aparência, os folheados são os objetos produzidos com materiais e mentais de menor valor comercial $^{30}$, mas que na etapa final de sua produção passam por um processo de galvanoplastia, no qual são cobertos por camadas de metais nobres como o ródio*, o ouro amarelo ou com tonalidades avermelhadas e a prata, conforme descrito pela pesquisadora. Nesta categoria de objetos folheados encontramos as réplicas de joias famosas, que o usuário, mesmo não possuindo o montante suficiente para adquiri-las, por status, sem o menor pudor, não deixa de ostentálas. Essas réplicas, ou seja, cópias quando são de boa qualidade e bem próximas da realidade enganam os olhos, porém a imitação poderá ser percebida ao manuseá-la, pela diferença de densidade, pois o peso do metal empregado para sua confecção geralmente é mais leve se comparado aos metais nobres utilizados na produção das peças originais.

Ao pesquisar sobre os objetos folheados encontramos também, como definição, outra nomenclatura que composta do prefixo semi, de origem latina, e que significa metade, combinado com a palavra joia, formando uma nova palavra: semijoia. Esta denominação que ao "pé da letra" significa a "metade de uma joia" é usada equivocadamente pelo mercado para definir os objetos folheados de melhor qualidade. Ou seja, criou-se uma subclassificação com base na suposta qualidade do objeto, no qual as semijoias seriam as peças que recebem um

\footnotetext{
${ }^{30}$ Gemas sintéticas que imitam as naturais e metais como o zinco e o cobre que constituem a liga de latão, por exemplo.
} 
número maior de camadas (banhos) de metais nobres e que, por isso, a sua durabilidade e/ou qualidade seria superior aos folheados. O equívoco ainda se estende e podemos observá-lo nas propagandas das empresas e nos eventos do setor ${ }^{31}$ que comercializam semijoias banhadas e semijoias folheadas como se fossem produtos diferentes. Diante disso podemos apostar em um palpite e atribuir esse mal-entendido a uma estratégia de marketing com o objetivo de valorizar os objetos folheados produzidos com banhos de melhor qualidade.

As bijuterias ou "bijus", como são popularmente conhecidas, representam a categoria dos objetos produzidos em material não nobre e por isso de valor financeiro mais acessível. Em alguns casos podemos encontrar bijuterias banhadas, porém este acabamento é dado com a intensão de proteção contra oxidações decorrentes do uso, do contato com produtos químicos ou do próprio oxigênio existente no ar, que, com o tempo, escurece a superfície das peças. As bijuterias também podem ser reconhecidas como réplicas das joias, mas neste caso, e diferentemente do que acontece com os folheados, elas não têm a pretensão de serem confundidas com peças de material nobre, e o intuito da cópia se resume à forma que, por sua vez, pode ser apenas um modismo da época.

Seguindo a ordem das categorias apresentadas temos as biojoias. Os objetos deste grupo possuem em sua composição elementos da natureza como, por exemplo, o capim dourado conhecido como o ouro vegetal do Jalapão (Tocantins) ou as sementes de jarina, que devido à sua coloração branca e dureza do material foi batizada de marfim vegetal. Recolhidos da natureza, de forma legalizada e sem causar danos à ela, os objetos produzidos nesta categoria pretendem atender aos conceitos de "sustentabilidade" tão em voga no momento. Alguns destes materiais orgânicos e de origem vegetal devem passar por um tratamento de liofilização ${ }^{32}$ antes de serem utilizadas como adornos pessoais. Conhecer as suas procedências e como foi realizado o seu processo de produção também são atributos agregadores de valor a este tipo de produto.

\footnotetext{
${ }^{31}$ Limeira em São Paulo é reconhecida como a capital do folheado, local no qual esse tipo de dúvida não poderia mais existir, porém podemos encontrar no Portal de Joias Limeira definições diferentes para folheados e semi joias, e que também seguem as distinções da qualidade das peças versus quantidade de camadas depositadas sobre a superfície das mesmas. Disponível em:< http://www.joiaslimeira.com.br/folheados/> e < http://www.joiaslimeira.com.br/semijoias/>. Acesso em: 12 de janeiro de 2017.

32 Liofilização é um método de desidratação do material orgânico, no qual a água é retirada por técnicas de sublimação. Esse tratamento preservando o material impedindo que bactérias e fungos se proliferem sobre ele iniciando assim o seu processo natural de decomposição.
} 
Para atender a demanda dos grandes centros urbanos por peças como um discurso natural e ecológico ${ }^{33}$, as biojoias também passaram por um processo de adequação e, hoje, podemos encontrar o ferramental utilizado na ourivesaria para dar acabamento na superfície das sementes; banhos galvânicos sendo aplicados em folhas secas e em lascas de cascas de árvores; bases para anéis e colares usados como suportes para sementes e outros elementos naturais sendo produzidas em diversos metais, dos mais nobres, como o ouro, aos não tão nobres como a prata; além da utilização das gemas coloridas e diamantes junto os materiais orgânicos.

Finalizando as categorias, a sexta e última que será apresentada foi nomeada como adornos de design. Este nome, ainda não publicado, surgiu a partir dos encontros com os meus orientadores no qual sentimos a necessidade de criar uma classificação especial para as peças desenvolvidas pelos designers. Esta categoria considera qualquer tipo de matéria-prima para a fabricação das suas peças, incluindo os metais nobres - considerados pela joalheria tradicional - e os materiais não convencionais como o plástico, o papel, o nylon, a resina, a madeira, o couro, as fibras vegetais, os tecidos, entre outros. Estes materiais poderão ser únicos na composição das peças ou se apresentarem combinados entre si. O que vai diferenciar estes adornos de design dos demais objetos, das outras categorias, é o fato deles serem criados por um profissional formado em design de joia, ou design de produto, e/ou que tenha realizado algum curso de aperfeiçoamento dentro do campo joalheiro; que seja um empreendedor, mesmo que ainda não legalizado; criando, produzindo e comercializando as próprias mercadorias, e fazendo o uso, ou não, de mão de obra terceirizada em alguma etapa da fabricação. O formato do objeto, o conceito desenvolvido e os processos metodológicos empregados na sua criação são relevantes para esta categoria, mas não são diferenciadores, pois estes quesitos também podem ser empregados na criação de peças de outras categorias, como as joias, folheados, bijuterias ou biojoias. "Esta categoria se configura porque usa, circula, multiplica e legitima aspectos e códigos que a definem e são conhecidos e reconhecidos pelos designers" (SANTOS, 2017).

$\mathrm{Na}$ categoria dos adornos de design podemos observar que a assinatura do designer/criador é reconhecida como um atributo de status pelos seus usuários, e assim, apresentar uma suposta explicação para o fato de encontrarmos no

\footnotetext{
${ }^{33}$ Como exemplo apresentamos o trabalho desenvolvido por: Maria Oiticica, Monica Carvalho, Rita Prossi.
} 
mercado peças de designer produzidas em prata e com gemas coloridas, chamadas de joias de designer e sendo oferecidas a custo igual ou superior ao de uma joia tradicional, em ouro, e pertencente a uma joalheria talvez menos reconhecida. Outro fato que merece ser mencionado é a existência dos designers que se denominam autodidatas e que se sentirão pertencentes a esta categoria. Estes profissionais que aprenderam o ofício praticando sozinhos, sem terem realizado algum tipo de curso ou qualquer outra formação na área, também produzem objetos que se enquadrariam no grupo dos adornos de design, porém se aceitos, estarão desprezando a condição principal que seleciona os objetos pertencentes a esta categoria sugerida, o de serem produzidos por um profissional formado em design ou que tenha em seu currículo algum curso de complementação na área de ourivesaria e afins. A categoria adornos de design abre espaço para novos debates sobre o assunto, deixando no ar a preocupação com a formação profissional de seus membros. Até que ponto ela é realmente importante?

Santos (2014) ainda nos apresenta vários sinônimos para o termo "adorno pessoal", que mapeados ao logo de sua da pesquisa, passaram a ser adotados, por ela, em sua vida profissional e acadêmica. Veremos então, que o termo joia e bijuteria, usados como categorias distintas na relação que acaba de ser apresentada, configuram entre estas denominações:

"Ao longo de sua história, ao nome adorno pessoal foram atribuídos diversos sinônimos: acessório, adereço, atavio, bijuteria, dixe, enfeite, folheado, joia, quinquilharia, ornato, ornamento e tesouro". (SANTOS, 2014:16)

Pesquisadora do campo, Santos (2014, p.16) adota os termos "adorno pessoal ou objeto de adorno pessoal, para significar qualquer objeto usado sobre o corpo" e assim, ao tratar do objeto joia, a pesquisadora não busca pelo "valor de circulação comercial" e sim, pelos atributos intangíveis ou simbólicos presentes nas peças, como por exemplo: os laços de sentimentais que unem casais que usam alianças de compromisso; e também aspectos como: originalidade, inovação no uso das formas, emprego de novos materiais, tendências de moda e etc.

"E faço a opção em considerar como joia, todos os objetos de adorno pessoal conceito independente do status dos materiais utilizados na sua confecção. Pois, o que vai ser considerado como relevante é a combinação de aspectos que tornam estes objetos valiosos para os usuários, tais como a originalidade da ideia que gerou a peça, o uso criativo e inovador dos materiais, o bom gosto da composição que forma a peça, adequação à moda, a preocupação com a 
produção, as referências culturais e outros aspectos que não estão necessariamente apenas vinculados ao valor de circulação comercial, tais como prazer, emoções e afetividade". (SANTOS, 2014, p.16)

A partir das definições acima apresentadas utilizarei as nomenclaturas joias, folheados e bijuterias de acordo com as definições aqui apresentadas, ressaltando também, que estas classificações poderão ser substituídas pelo leitor pelos termos "adorno pessoal ou objeto de adorno pessoal" e assim, promover uma continuação do pensamento científico de Santos, na busca por uma contribuição efetiva para um campo carente em bibliografia. Seguindo seus passos, gostaria também de esclarecer que, mesmo usados sobre o corpo e também com o intuito de adornar, os acessórios como: chapéu, lenço, luva, óculos, cintos e entre outros, não serão citados nessa pesquisa.

\section{2}

\section{Processos de criação e sistemas de produção das joias}

"Na natureza nada se cria, nada se perde, tudo se transforma." 34

Lavoisier

Os ensinamentos de Lavoisier podem ser aplicados ao setor joalheiro se pensarmos que tudo o que é criado e produzido, para atender ou gerar novas demandas de consumo, deriva de um processo anteriormente explorado, e o designer, reconhecido como um agente propulsor no mundo industrial, do desenvolvimento de produtos que, dentre diversas etapas, através da elaboração de um briefing; análise do perfil do usuário e de suas práticas de consumo; dos aspectos de mercado e de tendências de moda; e avaliação do sistema de produção, é capaz de atender (suprir) as carências do mercado por novas mercadorias.

Uma peça, linha ou coleção de joias pode nascer da necessidade de uma empresa ou de um designer empreendedor em fornecer novos produtos aos seus clientes, como acontece em datas comemorativas - Dias das Mães e Natal - de maior faturamento do comércio ${ }^{35}$; ou do desejo do próprio usuário final por

\footnotetext{
${ }^{34}$ Disponível em: < https://www.ebiografia.com/antoine_lavoisier/ >. Aceso em: 12 de abril de 2016.

35 São as datas mais importantes para o comércio no Brasil e que "fazem a alegria dos varejistas brasileiros". Daniela Moreira, 2012. Disponível em: < http://exame.abril.com.br/economia/as-datasmais-importante-para-o-comercio-no-brasil/ >. Aceso em: 09 de novembro de 2016.
} 
uma joia exclusiva, que atenda às suas expectativas momentâneas e, assim, vai buscar uma empresa especializada ou um profissional qualificado para tal realização.

Segundo dados apresentados pelo Sistema FIRJAN, representante das indústrias do estado do Rio de Janeiro ${ }^{36}$, o segmento de joias e bijuterias possui 3.105 empresas localizadas na região, e menos de 5\%, 132 empresas trabalham com a fabricação de joias, que geram 2.014 postos de trabalho, que representam $12,4 \%$ da cadeia produtiva $^{37}$. Independente do produto industrial, joia ou bijuteria, o estado ainda contribui na divulgação da marca "Rio de Janeiro" para o mundo e é reconhecido, pela instituição, como sendo o principal centro exportador do país.

Diante dos dados apresentados, do acúmulo de produtos considerados cópias disponíveis no comércio e da quantidade de egressos dos cursos de design que buscam uma colocação no mercado de trabalho, será que, de fato, essas empresas possuem um departamento de criação ou um designer graduado responsável pela criação de suas peças? E para o desenvolvimento desses produtos representantes da marca Rio de Janeiro, será que seguiram algum tipo de processo ou pesquisa para a sua criação?

Nos processos de criação de uma nova joia, a metodologia projetual de design parte da definição de uma questão em busca de uma solução, organiza passo a passo os conteúdos coletados e estabelece prioridades entre eles. Partindo da definição de um problema, ou da identificação de uma oportunidade embasada pelo segmento, pesquisas são realizadas e parâmetros projetuais determinados, para, a seguir, gerar ideias, testá-las, e quando aprovadas, resultarem em peças pilotos de novos produtos. Geralmente após avaliarmos os dados da pesquisa inicial, uma temática é escolhida para batizar as criações, promovendo assim um vínculo com o conceito elaborado para o projeto, alimentando, por tanto, a sua divulgação para o público consumidor e munindo a equipe de vendas com argumentos sobre o produto.

\footnotetext{
36 "Garantir o crescimento sustentável da indústria é a missão do Sistema FIRJAN, o representante de todas as indústrias do estado do Rio, que conta com 102 sindicatos e cerca de 7.103 colaboradores e 283 estagiários (em 16/09/2015). Com suas cinco organizações (SESI, SENAI, IEL, FIRJAN e CIRJ), o Sistema FIRJAN atua em áreas fundamentais, como a competitividade empresarial, a educação e a qualidade de vida do trabalhador e de seus familiares". 2016. Disponível em: < http://www.firjan.com.br/o-sistema-firjan/>. Acesso em: 08 de novembro de 2016. ${ }_{37}$ Dados do documento: Mapeamento Setorial: joias, bijuterias e afins/FIRJAN, 2016. Disponível em: < http://www.firjan.com.br/o-sistema-firjan/setores-de-atuacao/joias-e-bijuterias.htm>. Acesso em: 08 de novembro de 2016.
} 
Desenhos, ainda que em rabiscos para registro de ideias, são gerados primeiramente sem as preocupações técnicas, que se aplicadas nesse exato momento, poderiam agir com um limitador da criatividade, ao passo que, eliminariam inicialmente formas complexas que poderiam ser transformadas ao longo do desenvolvimento das peças. Após estudos e aprovação das formas, o desenho eleito é refeito dentro das medidas corretas e dos requisitos para a sua produção. Este é o momento de pensar nos encaixes, sistemas e articulações, nas espessuras de chapas e fios, em todo o tipo de detalhe e acabamento que uma peça irá receber durante a sua construção e, por isso, é vital a necessidade do designer conhecer e ter a experiência com os processos de produção e insumos utilizados para a criação de uma joia capaz de ser executada.

Alguns designers optam por trabalhar diretamente com a forma tridimensional, sem a realização de desenhos, e suas criações nascem da manipulação dos metais na banca, que materializam sua ideia. Neste caso, até um erro de execução pode se transformar em resultado inovador. Arames, papel, hastes e placas de madeira, acetato ou qualquer outro material que possibilite a montagem de estruturas são utilizados neste processo em que a forma é pensada e trabalhada tridimensionalmente. Após esta etapa, os experimentos podem ser registrados em desenhos, conforme citado anteriormente, ou servirem de modelos para a orientação da produção da peça definitiva.

Os processos que envolvem a produção de peças para o setor joalheiro do Rio do Janeiro foram selecionados de acordo com a oferta de mão de obra disponível no estado e como base nos dados apresentados pelo Guia Joia Carioca $^{38}$ - Guia de fornecedores de produtos e serviços para o setor de joias e bijuterias - sendo eles: artesanal; fundição; modelagem em cera; cravação; galvanoplastia; gravação; corte a laser; estamparia; esmaltação; prototipagem rápida e impressão 3D.

Lançado em 2012, o Guia Joia Carioca, é um projeto desenvolvido pelo APL JOIA CARIOCA ${ }^{39} \mathrm{O}$ instrumento criado é fruto da parceria firmada entre o SEBRAE e o Sistema AJORIO, e tem como principal finalidade a divulgação e ampliação do setor, contribuindo para o fortalecimento e integração de seus

\footnotetext{
${ }^{38}$ Guia Joia Carioca. Disponível em: < http://www.sistemaajorio.com.br/site/index.php/entidades2/notas-mainmenu-27/300-anuncie-no-guia-joia-carioca >. Acesso em: 12 de novembro de 2015.

39 "APL Joia Carioca é uma iniciativa conjunta do SEBRAE/RJ e da AJORIO em parceria com outras instituições relevantes para o setor de joias e bijuterias no estado: Sindijoias/RJ, SNCAPP, IBGM, Sistema FIRJAN, Governo do Estado (pela SEDEIS), Fecomércio, SENAC Rio, PUC-Rio e INT". Disponível em: < http://www.sistemaajorio.com.br/site/index.php/institucional-mainmenu63/apl-jcarioca-mainmenu-29 >. Acesso em: 05 de novembro de 2015.
} 
participantes. Além de incentivar uma nova conduta organizacional, por meio do modelo da excelência de gestão, o guia também pretende promover a valorização dos produtos de design, tendo em vista o reconhecimento dos mercados nacionais e internacionais (AJORIO, 2015)..$^{40}$

Distribuído gratuitamente pela AJORIO, o guia que teve a sua segunda edição impressa em 2015, ampliou o seu banco de dados, incorporando novas micro e pequenas empresas formalizadas e profissionais prestadores dos mais diversos tipos de serviços e produtos direcionados ao setor de joias e bijuterias. Organizar essas informações e dar continuidade ao projeto é uma das propostas da associação que pretende promover a integração entre os profissionais e as áreas que compõem a cadeia produtiva no Rio de Janeiro, difundindo informações e incentivando o crescimento do setor.

A prática de confeccionar objetos para serem usados junto ao corpo surgiu no decorrer da pré-história ${ }^{41}$, durante os primeiros períodos da Idade da Pedra Paleolítico e Neolítico - e através do uso intencional desses itens o homem estabeleceu uma forma de se diferenciar dos seus semelhantes, sendo legitimado por seus atributos de robustez e valentia, e por seu poder de exercer a liderança ou a cura. Os adornos criados eram produzidos com matérias-primas provenientes da natureza, e que também, faziam parte do cotidiano de seus portadores, como por exemplo: "conchas, seixos, cascas e fibras vegetais, raízes, sementes, pelos, peles, chifres, ossos, presas de animais e cerâmicas" (PROJOVEM ${ }^{42}$, 2006, p.15).

Com o domínio do fogo, a descoberta e manipulação dos minérios - cobre, bronze e ferro -, mesmo que de forma rudimentar, o Homo sapiens, como ficou conhecido o homem durante o Neolítico, experimentou várias formas de trabalhar com esses novos materiais, dando início às primeiras técnicas de fundição em metal, que foram utilizadas para a reprodução de utensílios, ferramentas e armas cada vez mais resistentes.

A fabricação de objetos metálicos com o emprego da fundição representou um marco na evolução da humanidade, e mesmo com comprovações apresentadas

\footnotetext{
40 Joia Carioca. Disponível em: < http://www.sistemaajorio.com.br/site/index.php/institucionalmainmenu-63/apl-jcarioca-mainmenu-29 >. Acesso em: 12 de novembro de 2015

${ }^{41}$ A pré-história compreende em três períodos distintos, sendo eles: Paleolítico ou Idade da Pedra Lascada (300.000 a 10.000 anos a.C.); Neolítico ou Idade da Pedra Polida (10.000 a.C. a 4.500 anos a.C.); Idade dos Metais - cobre, bronze e ferro - (4.500 a.C. a 3500 a.C.).

${ }^{42}$ ProJovem - Programa Nacional de Inclusão de Jovens. Arco Ocupacional Joalheria: guia de estudos.
} 
por pesquisas e registros arqueológicos sobre o assunto, muitas narrativas lendárias que supomos foram inventadas para tentar descrever como foi o início deste processo. Uma dessas histórias nos conta que o homem, um dia, ao esculpir em um favo de cera de abelhas a ponta de uma lança e posteriormente envolvê-la com o barro retirado do leito de um rio, permaneceu perto de uma fogueira, da qual, o calor emanado solidificou o barro, derretendo a cera que estava em seu interior, e liberando um espaço vazio com o mesmo formato da peça esculpida. Em seguida, uma mistura de metais foi derretida e derramada para preencher este vão deixado dentro do barro. Depois de algum tempo, esse ancestral de molde era quebrado liberando, enfim a peça reproduzida em metal. O desfecho final ficava por conta da observação, de que as etapas deste processo, que será descrito a diante, continuavam sendo executadas da mesma maneira que na pré-história, e a evolução só se fez presente no maquinário e no ferramental utilizado, em que o favo de cera foi substituído por um bloco compacto de cera sintética e o barro por moldes de borracha.

Avançando no tempo e prosseguindo com a história, passado e presente se misturam ao revelar que os processos de produção mais utilizados pela joalheria nos últimos tempos têm sua origem comprovada junto às memórias das antigas civilizações, com destaque especial para a joia egípcia, "pela variedade e beleza de suas composições gráficas, policromia - variedade de cores, materiais e técnicas diversificadas em ourivesaria". O processo da fundição por cera perdida, a cravação de gemas no metal e a gravação de desenhos sobre a superfície das peças, são técnicas artesanais que sobreviveram ao tempo e ilustram o fato apresentado. Já outras como o cinzelado*, a filigrana* e a granulação* que representam o preciosismo de detalhes do período, não tiveram o mesmo destino e raros são os profissionais que ainda as reproduzem, e com perfeição (PROJOVEM, 2006, p.16-17).

O método de produção artesanal das joias, que vem sendo praticado pelo homem desde o surgimento das antigas civilizações, mesmo com a presença de técnicas que padronizaram alguns passos da produção, é um processo manual, lento e complexo, inclusive, se comparado às mais modernas técnicas de modelagem virtual e impressão 3D atualmente ofertadas para 0 setor. Executadas individualmente por artesãos, que denominados ourives, necessitam, além da habilidade manual, um amplo conhecimento do ofício, pois são inúmeras e diferentes as etapas a serem realizadas durante o processo de fabricação das peças, tais como: preparação das ligas metálicas* ${ }^{*}$ fundição do 
lingote*; laminação*; trefilação*; soldagem*; lixamento*; polimento*; tratamentos químicos*; tratamentos térmicos* ${ }^{*}$, entre outas, e para a execução de cada uma dessas operações, ainda que joia ou bijuteria, vai requer um maquinário apropriado, limitando desta forma a produção de quem não os possui.

No caso da produção artesanal, há dados importantes a serem ressaltados, que se referem à capacitação dos ourives, na qual, a grande maioria dos profissionais atuantes no mercado teve sua formação construída através da troca de conhecimentos hereditários, algo aproximado à forma de ensino praticada pelos artesãos medievais, e atualmente, mesmo com uma razoável oferta de cursos profissionalizantes ${ }^{43}$ direcionados para o setor, poucos são aqueles que buscaram alguma qualificação técnica ou se mostram interessados com a evolução dos processos, e assim, limitam-se a expandirem sua atuação na área. Alguns profissionais que tiveram a oportunidade de aprender atuando como chão de fábrica ${ }^{44}$ em uma joalheria, quando desligados de suas funções na empresa, geralmente constituem suas próprias oficinas, passando a oferecer seus serviços diretamente aos clientes, tendo com base o aprendizado desenvolvido durante seu período de contratação, enfim, pode-se afirmar com alguma certeza que a maior parte dos profissionais da área teve uma formação prática em algum ateliê onde essas joias são fabricadas.

"Chão de fábrica" é uma expressão que surgiu durante o período da Revolução Industrial, que ainda, nos dias de hoje, é muito utilizada para designar o setor e os operários responsáveis exclusivamente pelas operações fabris, com metas e prazos estabelecidos a serem cumpridos, no entanto, sem participação nas tomadas de decisões estratégicas que envolvem assuntos relativos à gestão e ao desenvolvimento do próprio negócio, por exemplo.

As consequências da Revolução Industrial, iniciada na Inglaterra no século XVIII, modificou o mundo, influenciando diretamente na forma como as sociedades se relacionavam com o trabalho e os bens de consumo. Neste período, tivemos ocasião de observar a expansão e o desenvolvimento tecnológico acelerado das

\footnotetext{
${ }^{43}$ Os cursos de qualificação profissional, ou cursos livres, para o setor joalheiro são oferecidos pelo SENAC RJ e pelo SENAI (Sistema FIRJAN).

44 "Colaboradores que trabalham nas indústrias, geralmente em nível operacional. Chão de fábrica é também uma expressão utilizada para designar o conjunto de funcionários que executam tarefas produtivas na indústria, diferenciando-os daqueles, cuja atividade é gerencial e administrativa no processo". Dicionário Informal. Chão de Fábrica. Disponível em: < http://www.dicionarioinformal.com.br/ch\%C3\%A30\%20de\%20f\%C3\%A1brica/ >. Acesso em: 12 de novembro de 2015.
} 
cidades, que se adaptaram para receber os trabalhadores, imigrantes das zonas rurais, em busca de novas oportunidades de trabalho assalariado oferecidas pelas fábricas.

O artesão, que normalmente produzia em sua própria residência, seguindo suas próprias regras e atendendo, pelo sistema de encomendas, as demandas da sua comunidade, teve o seu ambiente de trabalho deslocado e adaptado para compor uma linha de produção e o seu ofício substituído pela manufatura mecanizada, em larga escala, impulsionada pelo advento das máquinas a vapor, e posteriormente por motores movidos à combustão instalados nas fábricas. Daí, foi obrigado a trabalhar nas fábricas e deixar sua residência apenas para moradia. Nesse processo, também perdeu a posse ou a propriedade dos meios de produção, isto é, de suas ferramentas e passou a depender das ferramentas ou maquinários dos seus patrões, enfim, passou da condição de artesão livre e dono de sua força de trabalho e passou a vendê-la como assalariado para as grandes indústrias. Houve, contudo, situações em que mesmo com a introdução do maquinário os artesãos continuaram a produzir como de costume, artesanalmente, porém agora segmentados, onde cada um, subordinado as exigências impostas pelos proprietários, se faz responsável por uma etapa distinta dentro do novo esquema fabril (FORTY, 2013, p.63).

Tendo em vista as facilidades apresentadas pela mecanização da produção, ou parte dela, podemos citar o sistema de fundição de metais que, aliado a produção artesanal, é um dos processos amplamente utilizado pela indústria joalheira para a padronização das mercadorias - peso/tamanho -, no qual a reprodução das peças é realizada em larga escala e em curto espaço de tempo, com redução de orçamento e controle prévio de matéria-prima. O que diferencia a produção das joias fundidas em ouro, nas cores: amarelo, branco e rosé ${ }^{45}$ ou em prata, para as bijuterias, em que geralmente se utiliza ligas de metais não nobres, são os equipamentos e a tecnologia empregada nos processos. Enquanto as bijuterias podem ser produzidas "no fundo do quintal" ${ }^{46}$, onde o tipo de metal fundido, geralmente de baixo valor, é derramado diretamente sobre o

\footnotetext{
${ }^{45}$ Rosé - termo em francês que significa: rosado.

${ }^{46}$ Conforme vimos o artesão normalmente trabalhava em sua residência e a expressão "fundo de quintal" refere-se ao espaço de sua oficina, mas a bem da verdade os artesãos urbanos não possuíam quintais, tal como ocorreu nas cidades brasileiras. Na Europa os espaços de moradia urbanos eram exíguos, daí a necessidade de vários andares sobrepostos. Aqui no Brasil, por conta do urbanismo português, as moradias das vilas coloniais que duraram praticamente até o século $\mathrm{XX}$, eram em geral casas térreas e possuíam uma fachada estreita, mais ou menos onze metros. Possuíam também um prolongado terreno para o fundo, onde se plantavam árvores frutíferas, e eventualmente fornos para assar o pão e aqui no caso metais. Trata-se, portanto do nosso fundo de quintal. (CIPINIUK, 2016).
} 
molde de borracha vulcanizada, já no caso das joias, principalmente as em ouro, vão requerer etapas mais complexas, e envolvimento de diversos profissionais especializados nas diferentes fases da produção. Podermos observar que além do valor agregado do tipo de metal utilizado, a qualidade do acabamento final apresentado nas peças, proporcionados por um processo de fabricação mais detalhado, são atributos importantes que conferem um diferencial às joias em ouro ou prata perante as bijuterias comercializadas no mercado.

A fundição de uma joia, pelo processo da cera perdida - microfusão - (Figura 2) em ouro ou prata, inicia-se com uma peça piloto, em metal, do qual se produz um molde em borracha vulcanizada ou silicone. A partir desse molde, injeta-se a cera reproduzindo uma quantidade infinita de cópias da mesma peça, que são organizadas e fixadas em uma haste mais grossa de cera, denominada "árvore de cera". Esta árvore é inserida em um cilindro metálico que posteriormente será preenchido com gesso cerâmico, que depois de seco e solidificado, terá a cera carbonizada em forno. Com a utilização de máquinas fundidoras profissionais, o metal é derretido, ligado $^{47}$ e levado a ocupar todo o espaço negativo, deixado pelo modelo em cera, dentro do gesso. Posteriormente o cilindro metálico contendo o gesso e o metal fundido em seu interior é resfriado em água, e o choque térmico provocado rompe o bloco de gesso liberando a árvore, que antes em cera, agora fundida em metal, e de onde as peças são separadas e cada qual seguirá em seu caminho dentro da produção.

As peças geradas a partir desse processo têm sua finalização desempenhada de forma artesanal, na qual temos as etapas: apuração com alicates, limas e lixas para retirar as marcas, como aquelas deixadas pelo canal de alimentação do metal; soldagem para unir partes que foram fundidas desmontadas; acabamento final de polimento e textura, ou seja, um processo mais longo em etapas complexas a serem seguidas, que se bem executadas, resultam em uma boa qualidade de fundição, minimizando o risco de defeito nas peças. $E$ isso tudo, contanto com a preocupação de se manter o teor correto do metal - ouro $750 \mathrm{e}$ prata 925 ou 950 -, padronizado pelo mercado brasileiro.

\footnotetext{
${ }^{47}$ Metal ligado é um termo utilizado pela joalheria que definir o metal que está preparado para ser empregado no processo de fabricação das peças. Ver glossário: ligas metálicas (p.147).
} 


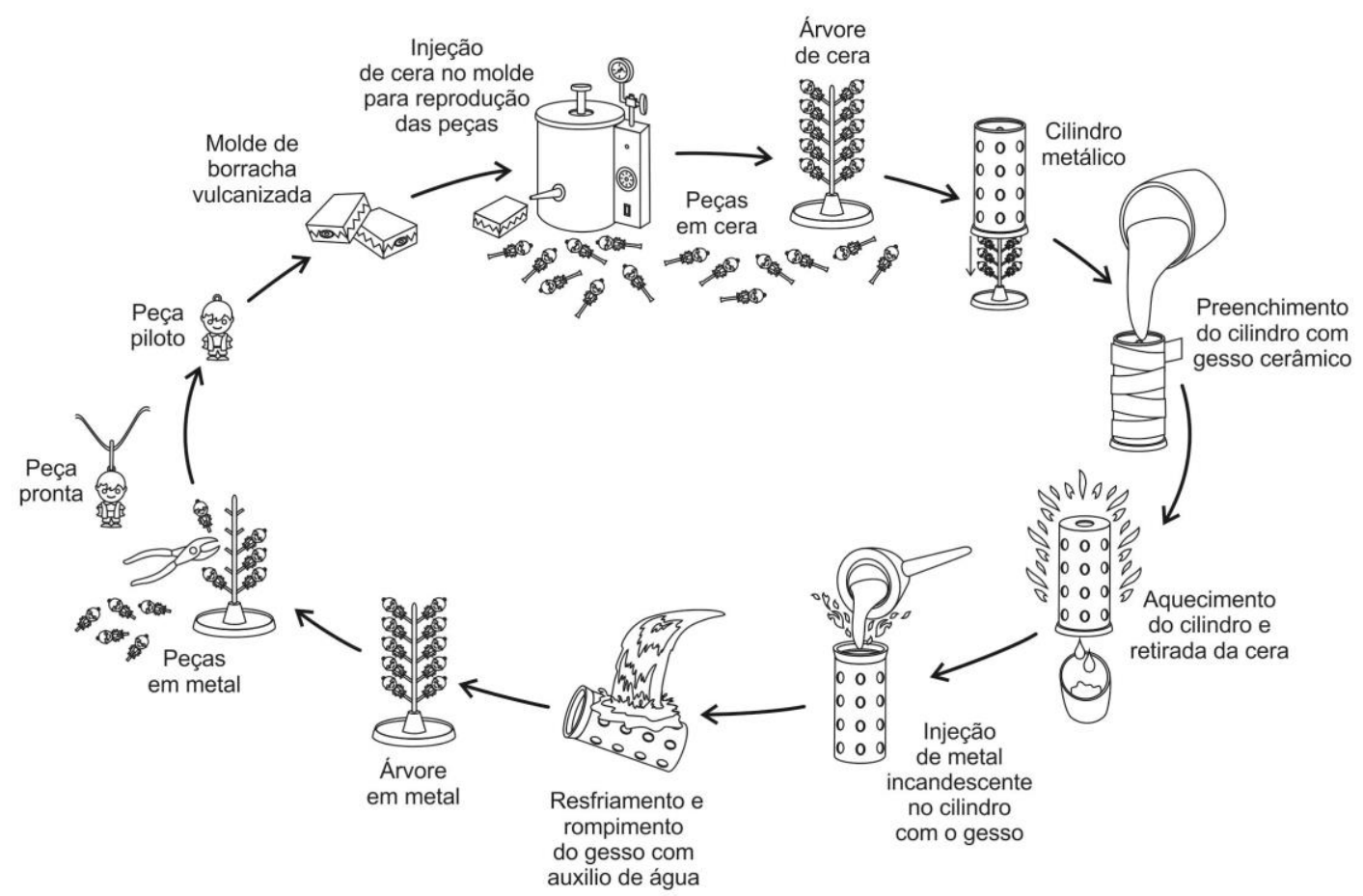

Figura 2 - Esquema das etapas do processo de fundição de uma joia.

Interagindo e complementado uma das etapas iniciais do processo de fundição, a modelagem em cera auxilia na criação dos modelos, que serão utilizados para a produção dos primeiros protótipos, conforme mencionado anteriormente. Modelar uma joia a partir de um bloco de cera, ao mesmo tempo em que demanda o emprego do ferramental apropriado, também exige certa habilidade e domínio de técnicas por parte do modelista, como é chamado pelo setor o profissional especializado por esculpir as peças em cera. O material utilizado, que aparentemente é de fácil manuseio, por sua vez, viabiliza a execução de formas mais complexas em menos tempo, se comparado ao trabalho executado em metal, além de proporcionar liberdade artística ao executor.

O modelo em cera é destruído, sendo literalmente derretido com a primeira fundição, que o transforma em uma peça piloto de metal. Apurada e finalizada, a primeira joia já pronta, além que servir para a fabricação do molde, do qual serão extraídas suas réplicas em cera injetada, geralmente é preservada para controle interno da produção de empresas ou designer autônomo, por exemplo. Depois do procedimento de moldagem, esta peça poderia ser encaminhada para a 
comercialização, porém, manter o exemplar original da joia é uma garantia futura para a integridade de sua reprodução, pois com o tempo, o molde poderá apresentar desgastes promovidos pelo uso, ou pelo mau uso, e assim, as cópias seriam produzidas com imperfeição, necessitando de um novo molde do mesmo modelo.

A modelagem em cera aliada à fundição, além de padronizar as joias e abreviar o tempo de produção, promove a redução no preço de custo final das peças, uma vez que o valor pago pelo modelo em cera é diluído pela quantidade de peças reproduzidas a partir do mesmo molde. Tanto o processo de fundição como o trabalho de apuração e montagem de joias fundidas é cobrado no mercado pelo peso das peças, ou seja, por grama de metal trabalhado, e desta forma este valor fica abaixo do custo de mão de obra de um ourives, que produziria toda a peça desde a preparação da liga aos acabamentos finais, independente da quantidade solicitada.

A cravação, do mesmo modo que a gravação são processos complementares a produção artesanal, e como os demais, necessitam de ferramental apropriado ${ }^{48}$ e mão de obra qualificada para sua execução. A cravação é utilizada para fixar as gemas, naturais ou sintéticas, nas joias, valorizando sua cor e seu brilho, disfarçando também alguma imperfeição. Podem ser decorativas, e assim, representar um diferencial na peça, ou servirem apenas para cravar as gemas o metal de forma segura.

Existem vários tipos de cravação (Figura 3), com diferentes nomenclaturas no mercado, entre elas, as mais conhecidas são: cravação à inglesa, onde o metal, exercendo certa pressão, circula toda a lateral de uma gema; cravação meiainglesa, no mesmo estilo da inglesa, porém com interrupções, simétricas ou não, que fixam a gema em determinados pontos; cravação em cantoneira, com o mesmo princípio da meia-inglesa, no entanto, usada para lapidações que possuem pontas a serem protegidas, como a ponta de uma gota ou os de cantos um triângulo; cravação com grifas, nesta as gemas são presas por garras de metal, que podem apresentar diferentes tamanhos e formatos; cravação brunida ou por pressão, quando acontece diretamente na chapa de metal; cravação pavê, com o preenchimento da superfície de uma peça por um conjunto de

\footnotetext{
${ }^{48}$ Os ferramentais utilizados para o processo de cravação são: buril com formatos e tamanhos diferentes; pau de goma para criar um suporte e ao mesmo tempo proteger partes da joia durante a execução do trabalho; perloir para arredondar os granitos e as terminações das garras; martelete para promover um leve deslocamento de metal sobre as gemas e criar texturas; borrachas especiais, limas e lixas para finalizar o acabamento.
} 
gemas pequenas e de tamanho uniforme, fixadas lado a lado por pequenos granitos (grãos) produzidos com o próprio metal da peça; cravação trilho ou carrê, nestas as gemas são encaixadas entre dois trilhos paralelos de metal.

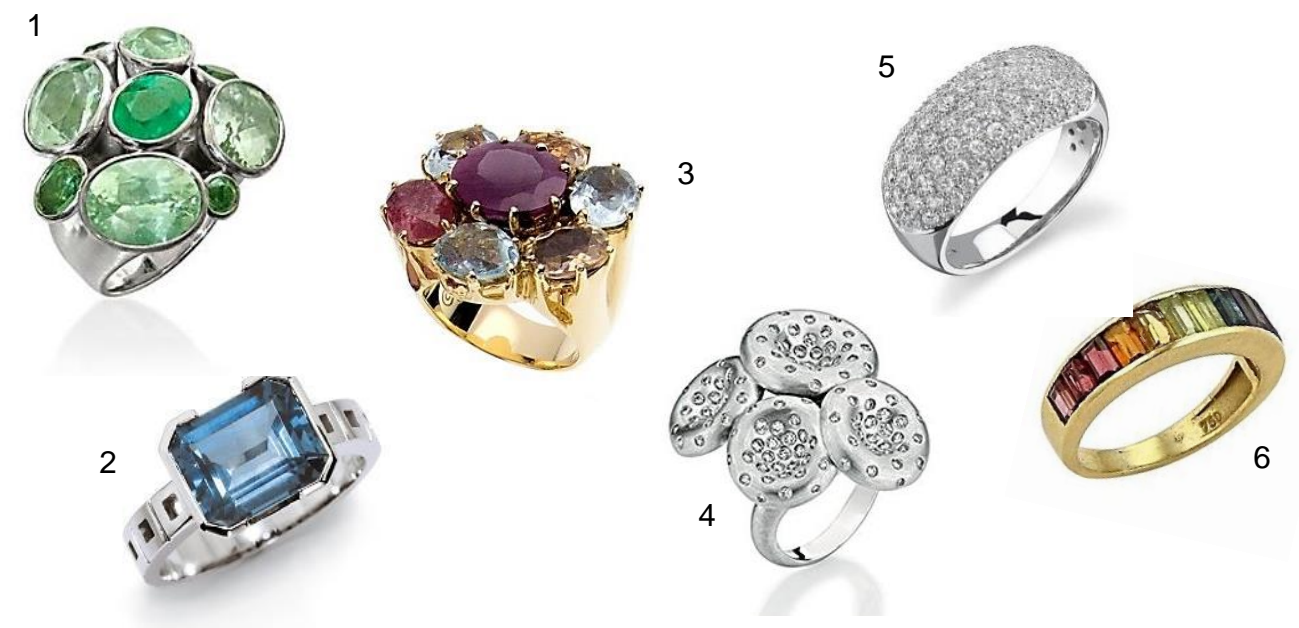

Figura 3 - Exemplos de cravação.

1. Anel em ouro branco com gemas verdes - esmeralda, turmalina e quartzo verde - de diferentes tamanhos em cravação à inglesa, Antonio Bernardo; 2. Anel em ouro branco com topázio azul em cravação meia-inglesa, Amsterdam Sauer; 3. Anel em ouro amarelo com gemas coloridas (berilo, citrino, rubi e turmalina rosa) em cravação com grifas, H.Stern; 4. Anel em ouro branco com diamantes em cravação brunida, Antonio Bernardo; 5. Anel em ouro branco com brilhantes em cravação pavê, Joias $18 \mathrm{Karat}$; 6 . Anel em ouro amarelo com gemas coloridas (ametista, citrino, quartzo verde, safira, turmalina rosa e turmalina verde) em cravação trilho, H.Stern.

As cravações podem ser combinadas entre si resultando novos modelos, e sua aplicação vai variar de acordo com o estilo de cada da peça, com o formato da lapidação da gema e com o efeito que se pretende alcançar, tanto nas joias quanto nas bijuterias. O profissional especializado para exercer essa função é nomeado pelo setor como cravador, que difere do gravador, que é o especialista que executa desenhos e inscrições sobre uma superfície de metal.

$\mathrm{Na}$ gravação, quando o trabalho é executado à mão livre, manuscrito, a experiência e habilidade do gravador, aliada aos instrumentos apropriados ${ }^{49}$, são fundamentais para se alcançar um bom resultado, com traços firmes, contínuos e espessuras bem definidas sobre superfícies planas, ou que apresentem alguma curvatura. As gravações podem ser automatizadas com o auxílio de

\footnotetext{
${ }^{49} \mathrm{Na}$ gravação são utilizados: buril e martelete. Um pantógrafo especial também pode ser utilizado para gravações internas de nomes em alianças.
} 
máquina a laser ${ }^{50}$, na qual os projetos executados têm como base os desenhos previamente desenvolvidos e vetorizados por softwares específicos, como por exemplo, Corel Draw, Illustrator InkScape.

Além da gravação, o laser permite a execução de cortes contínuos, que, em alta velocidade, resultam em peças de acabamento preciso e excelente qualidade. $\mathrm{O}$ corte a laser, que pode ser aplicado em chapas de diferentes espessuras e materiais, como: metais, vidro, acrílico, tecido, madeira, entre outros, e também será guiado por um projeto/desenho vetorizado. Este método, além da redução dos custos e prazos de produção; não necessita de investimento prévio com ferramental; produz menos sucata, pois o layout do corte da chapa pode ser organizado de acordo com a quantidade desejada de peças; não distorce o formato original da peça e ainda é eficiente na reprodução de bordas e os cantos vivos com precisão. Quando o material a ser trabalhado for algum tipo de metal precioso, como o ouro, por exemplo, existe ainda uma grande insegurança por parte dos fabricantes, em decorrência do seu elevado valor monetário perante o despreparo dos funcionários em lidar com esse tipo de matéria-prima. Por essa razão a produção de joias com a utilização do corte a laser é bastante restrita, podendo-se dizer praticamente nula, para o setor joalheiro no Rio de Janeiro, obrigando os interessados por este serviço a buscarem soluções em empresas de outros estados, valendo a observação de que a única empresa ${ }^{51}$ listada pelo Guia Joia Carioca tem sua sede em Minas Gerais.

A estamparia, que também é utilizada para o corte de chapas em metais de espessuras, difere do corte a laser, pois necessita de um ferramental apropriado para sua execução. Este método é destinado à produção em quantidade de peças leves e o seu processo resume-se em impor um determinado formato/desenho, proveniente de uma matriz, sobre uma lâmina de metal, produzida em ouro, prata ou latão. Quando necessário, depois de estampadas, as peças são embutidas* e soldadas artesanalmente, para então, se dar por finalizado o processo. As matrizes possuem uma vida útil de aproximadamente 2.500 cunhos, e com o uso prolongado, se desgastam perdendo a definição, e reduzindo a qualidade de impressão dos detalhes. De nossa parte, só conhecemos apenas um ferramenteiro que possui a capacidade de produzir as

\footnotetext{
50 Laser - sigla em inglês para Light Amplification by Stimulated Emission of Radiation que traduzido para o português representa: Amplificação da luz por emissão estimulada de radiação.

${ }^{51}$ Colen Industrial. Rua Alvarenga Peixoto 1380, sala 403. Santo Agostinho. Belo Horizonte (MG). Telefone de contato: (31) 3291 5000. Disponível em: < http://www.colenindustrial.com.br >. Acesso em: 29 de dezembro de 2016.
} 
matrizes/cunhos, aqui no Rio de Janeiro e ele não está mencionado no Guia Joia Carioca... E o único estabelecimento citado, que oferece o processo da estamparia, está com os cunhos gastos e as peças estampadas, que na maioria são medalhas de santos, saem sem boa definição. Ou seja, tudo leva a crer que não possuem uma preocupação de renovar as matrizes e manter um padrão de qualidade desejado pelo setor.

No Rio de Janeiro, outra técnica que também possui restrição quanto à oferta de mão de obra é a esmaltação*, que consiste em um procedimento decorativo de colorir a joia, produzindo uma camada vítrea sobre sua superfície metálica, ou preenchendo espaços vazados com a utilização de esmaltes ${ }^{52}$, resinas e colorantes especiais. Juntamente ao cinzel, à filigrana e à granulação, anteriormente citadas, ela faz parte do conjunto de técnicas ${ }^{53}$ desenvolvidas pela joalheria no período das Antigas Civilizações - grega, romana e etrusca - e que hoje estão descontinuadas pela falta de interesse dos artesãos; pela dificuldade de encontrar ferramental e a matéria-prima adequada, geralmente importada de outros países, para a sua reprodução; e pela complexidade do processo que não tem o seu valor reconhecido financeiramente pelo usuário final, ou seja, a esmaltação a quente além de embelezar encarece o produto.

Existem dois processos para a execução da técnica de esmaltação*: a frio e a quente. Na esmaltação a frio temos o uso da resina poliéster ${ }^{54}$, que pode permanecer cristalina, receber coloração transparente através dos pigmentos, ou opaca com a utilização de corantes. A peça deve possuir um espaço delimitado para receber a resina líquida, que quando mistura a um catalisador provocará uma reação química conhecida por polimerização, resultando no endurecimento da mesma. Já na esmaltação a quente, o esmalte é o componente principal. Comercializado sobre a forma de um pó ou em pequenos fragmentos, sua composição original também é transparente, podendo receber coloração através da mistura com óxidos metálicos e outros corantes, permanecendo translúcido ou colorido ou se tronando opaco ou ainda opalescente ${ }^{55}$. Quando aquecido em forno, o pó de sílica fundisse aos óxidos e a mistura muda de estado físico,

\footnotetext{
${ }^{52}$ Composição a base de sílica outros óxidos metálicos, como o ferro, o cobre e o manganês. A sílica também é o componente fundamental do vidro.

53 "As técnicas antigas seguem em produção no Velho Mundo e nos países em que a joalheria é tradição". (SANTOS, 2017).

54 Derivado de petróleo, que apresenta cheiro muito forte, podendo provocar intoxicação no manuseio sem os devidos equipamentos de segurança - máscara de gases e luva de proteção.

${ }^{55}$ Com a aparência de uma opala, gema composta por óxido de silício e água, e que por isso possui um fenômeno chamado "jogo de cores", ou seja, quando movimentada exibe muitas cores e partículas que podem ser fluorescentes.
} 
passando de sólido a líquido e assim é depositado sobre o espaço na peça a qual irá ocupar depois de solidificada. Para finalizar o processo, a peça deve ser levada ao forno para uma queima a aproximadamente $800^{\circ} \mathrm{C}$. Nessa modalidade, de esmaltação a quente, existem vários métodos que foram se aperfeiçoando ao longo de sua prática, nos quais destacamos: basse-taile*, cabochonné*, cloisonné*, champlevê ${ }^{*}$ grisaille*, limoges* e plique-à-jour*, cada um é aplicado de uma forma diferenciada, respeitando o projeto da peça e gerando resultados diferenciados.

Desde a descoberta ao manuseio primitivo dos metais por nossos ancestrais, passando pela origem milenar da prática da ourivesaria, podemos observar que, ao longo dos tempos, as técnicas que envolvem a produção das peças foram se adequando às novas necessidades de consumo e as novas tecnologias que surgiram com o desenvolvimento da humanidade.

A tecnologia chegou ao setor joalheiro e atualmente, com o auxílio de softwares específicos de modelagem 3D, como o Rhinoceros, o Matrix e o 3DS Max, por exemplo, é possível modelar uma joia virtualmente, de forma rápida e precisa, seguindo todos os requisitos que seriam levados em consideração se a mesma, de fato, estivesse sendo produzida. Detalhes como: espessuras de chapas, encaixes, articulações, recortes, vazados, boleados, cantos vivos, texturas, gravações, garras e virolas para cravação de gemas, entre outros, ou seja, tudo deve ser calculadamente projetado seguindo as dimensões reais, porém executado dentro de um espaço virtual. Sendo assim, podemos afirmar que uma peça modelada em 3D terá uma chance maior de assertividade quando executada por um profissional que, além de dominar as ferramentas oferecidas pelo programa, possui amplos conhecimentos nas diferentes etapas do processo de fabricação das joias. Caso contrário, o projeto corre o risco de apresentar alguma falha em um dos requisitos citados a cima e com isso, ter a sua execução inviabilizada.

O Rhinoceros, ou Rhino como conhecido, é o principal software utilizado pelo setor joalheiro para o desenvolvimento virtual de projetos. Criado com base na tecnologia NURBS ${ }^{56}$, inicialmente funcionou com um plug-in ${ }^{57}$ para o AutoCAD, mas com o avanço da tecnologia e a demanda por softwares que operassem no

\footnotetext{
${ }^{56}$ NURBS - Non Uniform Rational Basis Spline. Modelo matemático usado em softwares graficos para a representação de planos, superfícies e curvas.

57 Plug-in - termo em inglês usado para definir softwares menores que são criados para adicionar alguma função específica a outro software.
} 
universo 3D, se tornou independente e hoje atende a vários campos que atuam com desenvolvimento de produtos como: arquitetura, cenografia, design de móveis, de utensílios domésticos, de acessórios, de calçados, automobilísticos, aeroespacial, personagens de jogos e etc. A configuração do seu ambiente de trabalho é apresentada com a tela dividida em quatro espaços nos quais, em três deles, a modelagem é executada tecnicamente seguindo a construção de suas vistas ortogonais - superior, frontal e lateral direita ou esquerda - e no quarto espaço, localizado no canto superior e à direita da tela, simultaneamente ao desenho construído das vistas, uma perspectiva é formada, possibilitando assim uma melhor visualização, ao rotacionar ou inclinar o modelo, de todos os detalhes, internos e externos, das laterais, da parte superior ou da inferior da peça.

O Rhino também oferece recursos que são muito úteis para um planejamento de produção ou mesmo para a finalização de um pedido com apresentação de orçamento para o cliente. Após a joia concluída, é possível medir o volume da massa modelada e assim calcular quanto seria o seu peso final se produzida em ouro, prata ou qualquer outro metal. Também, com o auxilio de um plug-in de renderização, aplicar o material - metal e gemas -, texturas, simular reflexos, sombras, ou seja, montar uma imagem que possibilite a visualização da joia, com características bem próximas a realidade, antes mesmo ser produzida. Ter um portfólio virtual e utilizar sites com e-commerce para divulgar e comercializar seus produtos é uma boa estratégia para designers empreendedores que não possuem capital disponível para investir e produzir todas as peças de uma nova coleção e assim, só seriam executadas aquelas encomendadas via web. Porém, essa ideia ainda é pouco explorada, visto que muitos não se interessam por essa tecnologia ou ainda não possuem um bom desempenho com o software e seus complementos.

O processo iniciado com a modelagem virtual tem sua continuidade com a impressão 3D, ou prototipagem rápida, das peças projetadas. É neste momento que uma joia virtual se transforma em um modelo tangível, que poderá ser apresentado e testado pelo cliente. Os protótipos impressos reproduzem com perfeição todos os mínimos detalhes que previamente foram modelados. Existem disponíveis no mercado vários estilos de maquinários que vão desde as fresadoras, com capacidade para esculpir em um bloco de cera, às impressoras 3D que trabalham depositando camada por camada de material até a finalização da peça. Após a impressão concluída, no caso da cera, o modelo pode ser 
encaminhado direto para a fundição ou, se em resina, extrair uma borracha, reproduzir os modelos em cera e montar uma árvore de fundição... E a sequência dos processos, já descritos anteriormente, se dá de forma individual e manual para cada peça. Sendo assim, podemos concluir que por mais avançada que seja a tecnologia empregada ela ainda não abraça o processo completo, indo buscar os processos manuais para a apuração, montagem e acabamentos finais.

Transitando entre esses dois universos, real e virtual, notamos que ainda hoje, em pleno século XXI, existe uma grande resistência por parte dos profissionais envolvidos como o campo joalheiro do Rio de Janeiro. Por um lado temos os modelistas que acham que serão substituídos pelos softwares de modelagem 3D; os ourives que acreditam que só serão procurados para trabalhos de acabamento e montagem de peças modeladas virtualmente, ou seja, serviços mais simples e por isso com valores inferiores; as empresas que utilizam a ferramenta pensando em produzir cópias precisas das peças de seus concorrentes e deixando de lançar suas novidades no mercado; e os designers, quando não conhecem os processos manuais de fabricação das joias e/ou as ferramentas de modelagem disponibilizadas pelos softwares, e mesmo assim se aventuram no universo virtual, resultando na produção de peças e protótipos defeituosos e que precisarão ser refeitos, gerando custo de material e do tempo dedicado ao trabalho. Com todas essas ressalvas, acreditamos que ainda levará muito tempo para que a máquina seja capaz de substituir tudo o que é feito com a mão e a sensibilidade humana. Será que veremos o dia em que a máquina operando no campo joalheiro vai substituir por completo o homem? 


\section{3}

\section{O campo joalheiro no Rio de Janeiro}

O campo joalheiro no Rio de Janeiro é constituído por: empresas - joalherias e fabricantes - que influenciam o mercado lançando coleções e ditando tendências; organizações e entidades de classe que contribuem para a institucionalização do campo, incluindo desde as organizações envolvidas com os processos de profissionalização e ações de regulamentação, aos projetos de cunho social, desenvolvimento político, econômico e tecnológico; instituições de ensino que contribuem na formação e capacitação dos profissionais envolvidos com o campo; designers empreendedores autônomos ou contratados pelas empresas do campo, que por meio de suas criações, podem ser reconhecidos também como formadores de opinião. Podemos afirmar, inclusive, que o campo, ao promover relações entre seus membros, configura-se como instância de legitimação e assim, reconhecido por todos como cenário de notoriedade e divulgação, ou ainda, segundo Bourdieu, como um espaço de competição, mesmo que disfarçada.

"Berço da indústria joalheira no país", segundo dados apresentados, em 2015, pelo Sistema AJORIO, o Rio de Janeiro foi classificado como o terceiro maior estado brasileiro em relação ao volume de produção de joias, representando "20\% da produção industrial, movimentando cerca de R $\$ 1,4$ bilhões por ano" 58 , ficando atrás do estado de São Paulo, considerada a maior metrópole financeira do país e que possui os dois importantes polos industriais, que atendem ao setor joalheiro, localizados nos municípios interioranos de Limeira e São José do Rio Preto; e do estado de Minas Gerais, com suas fontes de riquezas minerais de onde provem grande parte da nossa matéria-prima, como o ouro, diamantes e as gemas coradas brasileiras, contando com os principais centros mineradores brasileiros situados nos municípios de: Araçuaí, Corinto, Diamantina, Guanhães, Governador Valadares, Itabira, Ouro Preto e Teófilo Otoni.

\footnotetext{
58 AJORIO. Disponível em: < http://www.sistemaajorio.com.br/site/index.php/institucionalmainmenu-63/sistema-ajorio/21-institucional/-institucional/572-sistemaajorio >. Acesso em: 20 de novembro de 2015.
} 
Conforme mencionado, atualmente, o estado do Rio de Janeiro está atrás dos estados de São Paulo e Minas Gerais, porém esse posicionamento não foi sempre assim. Já ocupamos um lugar de destaque na biografia da produção de joias em nosso país. Analisando a história e os fatos ocorridos durante o período colonial, mais precisamente na segunda metade do século XIX, em que "a ourivesaria foi difundida nas principais cidades do Brasil, e o Rio de Janeiro tronou-se referência na produção e oferta de objetos de adorno pessoal dentro dos padrões de moda vigente", e mesmo com todas as restrições impostas à prática do ofício na época, endereços como a Rua dos Ourives ${ }^{59}$ e a Rua do Ouvidor concertavam oficinas e os mais diversos tipos de profissionais envolvidos com a ourivesaria, transformando a localização em um centro importante de produção e comercialização de joias. (PROJOVEM. Guia de Estudo, Arco Ocupacional - Joalheria, 2006, p.31).

Em 2012, o documento: "Mapeamento da Indústria Criativa no Brasil" ${ }^{60}$, um estudo desenvolvido pelo Sistema FIRJAN ${ }^{61}$ - Federação das Indústrias do Rio de Janeiro -, classificou a cadeira produtiva que atende ao setor joalheiro presente nos estados da Bahia, Minas Gerais, Rio de Janeiro, Rio Grande do Sul e São Paulo, como um parque industrial diversificado, formado por "empresas de lapidação, de joalheria, de artesanato de pedras, de folheados e de bijuterias". Conforme os dados apresentados, na época, o estado do Rio de Janeiro foi considerado o principal polo exportador do Brasil; foi o cenário no qual as grandes joalherias, reconhecidas internacionalmente, lançaram suas coleções de design exclusivo para atender a uma seleta clientela, além da demanda natural de estrangeiros em visita ao país; momento em que o consumo de joia foi popularizado e as empresas de pequeno porte, com produtos mais acessíveis, investiram na oportunidade; foi também a época na qual os designers empreendedores e as pequenas joalherias cariocas apostaram na criação, produção e valorização de peças com design, em busca do fortalecimento do

\footnotetext{
${ }^{59}$ A antiga Rua dos Ourives mudou de nome em 1936, e atualmente se chama Rua Miguel Couto, em homenagem o médico pesquisador na área de saúde pública, que teve seu consultório nesse logradouro.

60 Dados apresentados pelo documento: "Mapeamento da Indústria Criativa no Brasil" - Cenário da Cadeia de Joias e Bijuterias do Rio de Janeiro, 2012, Sistema FIRJAN. Disponível em: < http://www.firjan.com.br/lumis/portal/file/fileDownload.jsp?fileld=2C908A8A50019C2B01501574A08 8159 C\&inline $=1>$. Acesso em: 18 de novembro de 2015.

61 "Representante de todas as indústrias do estado do Rio". "Atua em áreas fundamentais, como a competitividade empresarial, a educação e a qualidade de vida do trabalhador e de seus familiares". Disponível em:< http://www.firjan.com.br/o-sistema-firjan/quem-somos/>. Acesso em: 18 de novembro de 2015.
} 
campo, e em relação à invasão das mercadorias importadas de outros países ou mesmo das fabricadas por outros estados. Além disso, a pesquisa identifica que o declínio do setor produtivo no Rio de Janeiro, principalmente entre os designers empreendedores e as pequenas joalherias, aconteceu a partir da década de 1990, que fragilizados pelas crises econômicas, pela falta de incentivos fiscais, pelos impostos elevados e crescente burocracia enfrentaram dificuldades para o seu desenvolvimento.

Para maior compreensão, o campo joalheiro no Rio de Janeiro será apresentado de forma segmentada, começando pela ponta da cadeia produtiva, na qual é ocupada pelos os artesãos que manipulam a matéria-prima - metal e pedras preciosas - com destaque aos ourives que transformam o metal, em geral o ouro e a prata, em joias; os lapidários que a partir das gemas em estado natural ${ }^{62}$ conferem a elas formas comerciais ${ }^{63}$, ressaltando a cor e o brilho das pedras preciosas; os cravadores, que são especialistas nas técnicas de engaste, ou seja, fixar as pedras precisas nas joias; e por fim os fundidores, que desenvolvem um sistema de fabricação peculiar, em que peças iguais são reproduzidas em grande quantidade, independente do tipo de metal.

As oficinas que se dedicam exclusivamente à produção de peças manuais, com ou sem o auxílio da técnica de fundição, geralmente são de pequeno porte ou ainda se encontram na informalidade. Elas empregam ourives, cravadores e polidores e sua sobrevivência depende das encomendas que desenvolvem para as joalherias, designers ou vendedores autônomos que comercializam o produto final acabado, ou seja, que não possuem fabricação própria, ou apenas alguma parte do processo, e por isso terceirizam a produção. Além dessas oficinas, que reúnem profissionais para atender a todas as etapas da produção das peças, podemos encontrar também as que são segmentadas, específicas em um determinado processo como: cravação, gravação, fundição e banhos metálicos (galvanoplastia), além daquelas que produzem somente os insumos - correntes, pinos, tarraxas e fechos - a serem usados durante o processo de montagem das joias. Sendo assim, podemos afirmar que a manutenção desses espaços, bem como a atividade desses profissionais depende diretamente do consumo de joias.

\footnotetext{
${ }^{62}$ Gemas em estado natural, ou bruto é o termo usado para classificar as pedras preciosas encontradas na natureza e que não passaram por nenhum processo industrial de transformação da sua forma.

${ }^{63}$ Lapidadas em facetas planas ou como superfícies arredondadas, com nos cabochões.
} 
Das oficinas, local destinado basicamente à produção das joias, passamos agora sua comercialização, ou seja, o momento no qual o produto é exposto para venda e onde também, o cliente pode vir a manifestar sua opinião e suas intensões de consumo. Nesta etapa, primeiramente ressaltaremos as grandes joalherias, que representam o mercado de luxo no Brasil, com a H.Stern e a Amsterdam Sauer, por exemplo, que sustentam o título de empresas "verticalmente integradas", produzindo suas joias do garimpo ao consumidor final, e que teoricamente, desenvolvem suas coleções exclusivas, produzem em suas oficinas e comercializam em lojas próprias. Já as joalherias de massa, localizadas em outra categoria de consumo, estão voltadas para atender um público de menor poder aquisitivo, com a Vivara e a Monte Carlo, por exemplo. Mesmo com o desenvolvimento de peças exclusivas para formar pequenas coleções assinadas, com produção terceirizada, essas empresas também revendem peças de fabricantes nacionais e estrangeiros, com o objetivo de minimizar os custos de sua produção interna e periodicamente apresentarem novidades em suas vitrines. Muitos desses fornecedores de joias, que atendem ao campo, trabalham com o sistema de consignação de peças, ou seja, o risco da venda é do fornecedor e não da joalheria, que por sua vez, poderá trocar a mercadoria, ou mesmo liquidar as peças, caso elas não atendem ao gosto de sues clientes em um determinado período de tempo.

$\mathrm{Na}$ sequência do mapeamento, chegamos às associações de classe, com a AJORIO, por exemplo, que dedica seu trabalho para a propagação do campo joalheiro no Rio de Janeiro; e as instâncias de institucionalização que compreendem as universidades, os cursos profissionalizante e os cursos livres oferecidos pelos ateliês, e que buscam atender a todas as pessoas, sem distinção de classes social, faixa etária, e nível de instrução, mas que estejam interessadas no aprendizado das técnicas tradicionais que envolvem o ofício da ourivesaria.

Quanto aos designers que atuam no campo joalheiro, podemos encontrar os que trabalham com contrato assinado de dedicação exclusiva, e no regime $\mathrm{CLT}^{64}$, para as joalherias, e o grupo dos empreendedores que desenvolvem e comercializam suas próprias criações. Dentro desse último grupo, bem maior porque são poucas as joalherias que possuem um departamento de criação e empregam esses profissionais no estado do Rio de Janeiro, também

\footnotetext{
${ }^{64} \mathrm{CLT}$ - Consolidação das Leis do Trabalho.
} 
destacamos os designers que em suas oficinas caseiras desenvolvem o processo completo - criação, fabricação e comercialização - e os que terceirizam a produção, voltando seus esforços para as etapas de criação e posteriormente a divulgação e venda de suas peças.

Conforme podemos verificar, nas relações representadas pelo diagrama abaixo (Figura 4), os profissionais envolvidos com a produção das joias, que compõe a ponta da cadeia produtiva - ourives, lapidários, cravadores, polidores, fundidores e gravadores -, se comunicam com fornecedores de matéria-prima, metal e pedras preciosas e com fornecedores de insumos, com correntes, pinos e demais acabamentos. $\mathrm{E}$ todos esses citados, se relacionam com os designers, que por sua vez se conectam com as joalherias, sendo por intermédio de contrato exclusivo ou prestação de serviço terceirizado, e que também estão ligados aos vendedores autônomos. As instituições de ensino, bem como as entidades e associações de classe, juntas, fecham o círculo englobam todos os participantes e delimitando o campo joalheiro no Rio de Janeiro.

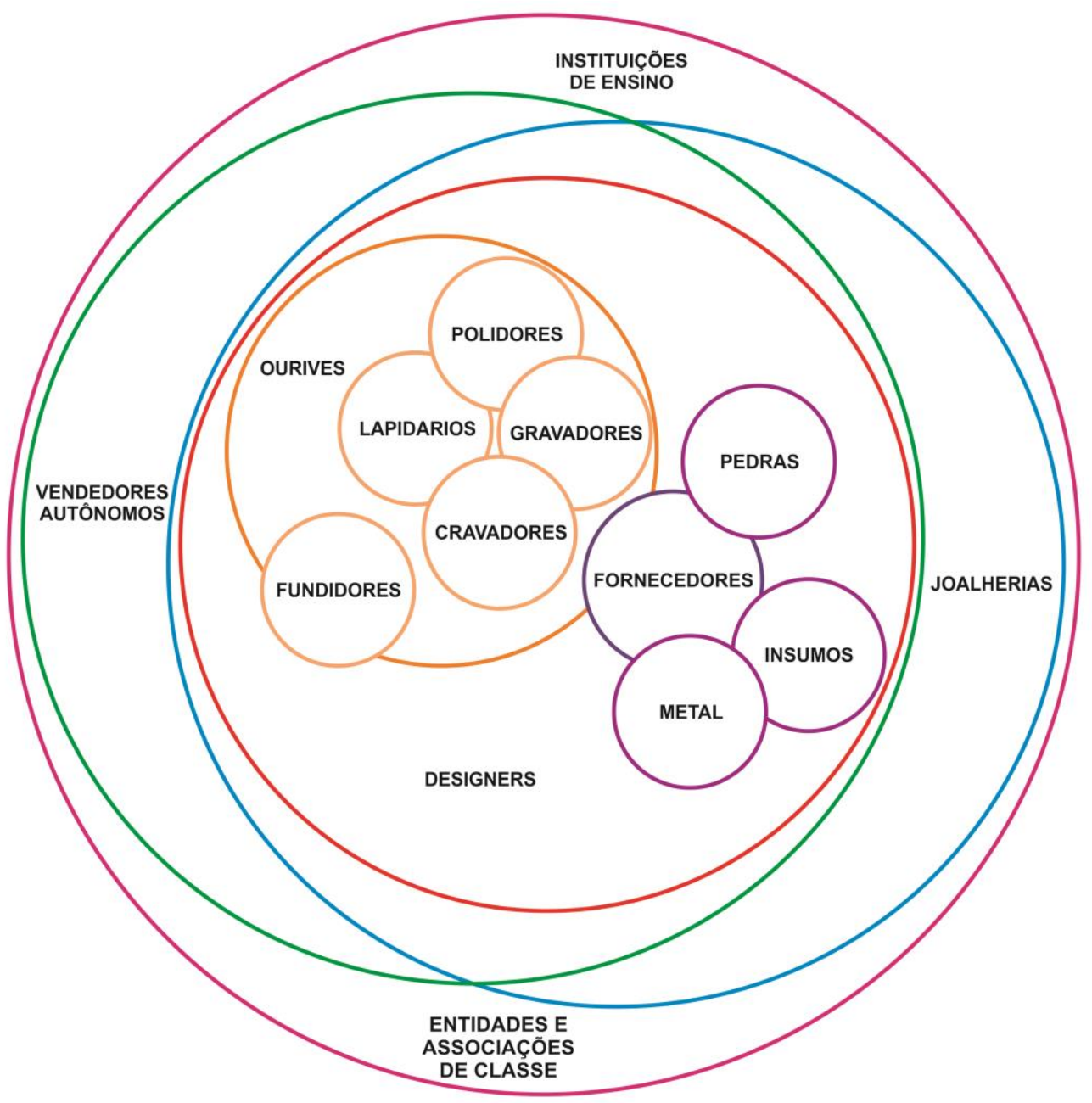

Figura 4 - Mapa do campo joalheiro do Rio de Janeiro. 


\section{1}

\section{Os objetos e o conceito construído no campo joalheiro do Rio de Janeiro}

Considerando a forma como Bourdieu divide os agentes que operam em um campo - produção, recepção e circulação - examinamos o campo joalheiro do Rio de Janeiro investigando aqueles que produzem, os agentes que se dedicam à produção das joias; aqueles que compram ou consomem (recepção) esse tipo de artefato e finalmente os "comerciantes" (circulação), isto é, os agentes que legitimam as joias como algo necessário, como um valor cultural e financeiro. São aqueles que para vender joias, inventam ou contratam pessoas para produzirem frases tais como "os diamantes são eternos" e daí quando um jovem precisa demonstrar à sua noiva suas intenções matrimoniais, oferece à sua amada um objeto que traz consigo a noção de eternidade ou durabilidade dos laços afetivos que está propondo e que em nossa sociedade são muito importantes. Neste tópico, realizaremos apenas a análise dos objetos que representam o campo sob a ótica de um desses grupos que se ocupam da circulação ou definição crítica dos valores simbólicos e financeiros desses objetos, os comerciantes.

Representados pelas joalherias e pelos designers autônomos, esse grupo pode ser visto como a "ponte" entre os outros, pois é através de seu trabalho que as peças (joias) produzidas são expostas, divulgadas, comercializadas, chegando às mãos dos consumidores, movimentando a economia e também criando tendências, legitimando ou consagrando valores que se transformam rapidamente em consumo. Ou seja, esses agentes do campo produzem o "desejo", a vontade de adquirir uma joia. Quanto às joalherias, podemos encontrar subdivisões de acordo com a matéria-prima empregada na fabricação das joias e o estilo de produto comercializado, sendo: i) as que trabalham com metais preciosos e, em geral, agregam o uso de diamantes e/ou pedras preciosas; ii) as que trabalham somente com metais preciosos, em especial o ouro amarelo ou branco; iii) as que trabalham com vários metais, ou seja, um mesmo modelo pode apresentar uma versão em ouro ou prata, com o uso de diamantes ou não; iv) as que trabalham exclusivamente em prata, com o uso de diamantes e/ou pedras preciosas; v) as que utilizam os materiais ditos "não convencionais" ao campo como couro, borracha, madeira, palha, acrílico, entre outros, independentemente do tipo de metal ou da utilização de gemas e, por 
fim, vi) as que utilizam banhos para cobrir peças de metais não nobres. ${ }^{65}$ Quanto ao trabalho desenvolvido pelos designers, podemos aplicar também essas subdivisões e ainda, encontrar as peças rotuladas como "únicas", criadas sem o intuído de reprodução e com materiais ainda mais incomuns ao campo, que não é o caso das joias comercializadas pelas joalherias. Esse grupo de agentes emprega a noção romântica da genialidade artística que é base de uma produção autoral. Daí baseados em uma noção tradicional de que arte não tem preço, podem comercializar suas joias como obras de arte únicas e por essa razão mais caras, pois possuem um valor simbólico "agregado", pois trazem consigo valores culturais imemoriais em relação aos objetos que produzem. No setor joalheiro há ainda a distinção pelo material usado, isto é, o material natural, único na natureza - gemas, por exemplo -, e feito pela natureza. A classificação das gemas é uma forma de legitimação de qualidade, distinção, autenticidade.

Assim, o que será analisado nesse tópico são os objetos já existentes, sem entrar no mérito de que a representação da identidade ou valores simbólicos do campo estão sendo realizados de forma adequada ou não. Questões sobre identidade ou valorização simbólica envolvem muito mais do que uma análise de vitrines. Elas atravessam a história, se comunicam com vários momentos da sociedade, são muito mais complexas e vão muito além das simples opiniões daqueles que, atualmente, ousam tentar defini-la dentro e para o campo joalheiro no Rio de Janeiro.

Pensar em um produto, uma joia, ou mesmo em uma coleção de peças que represente o campo joalheiro do Rio de Janeiro, pode até ser uma tarefa aparentemente fácil, se levarmos em consideração a ideia de "Cidade maravilhosa, Cheia de encantos mil..."66, que durante anos foi construída e reiterada por seus agentes sociais de legitimação. ${ }^{67}$ Podemos assim observar, que o resultado da imagem mental gerada, ao idealizar o que seria esse "Rio de Janeiro", é de um lugar banhado pelo mar, com corpos esculpidos em

\footnotetext{
${ }^{65}$ As peças de metais não nobres - latão, zamac, cobre e ligas de estanho - são chamadas de "bruto". Estas peças depois de banhadas por ródio, ouro ou prata, por processo galvânico, são denominadas bijuterias ou folheados.

${ }^{66}$ Marcha de carnaval, composta em 1935, por André Filho, que se tornou o hino oficial da cidade do Rio de Janeiro.

${ }^{67}$ Os próprios moradores, principalmente os dos bairros da Zona Sul da Cidade; público nacional e estrangeiro em visita ao Rio; empresas e profissionais que trabalham na área do turismo; indústria da moda e fotografia; telenovelas brasileiras, principalmente da Rede Globo de televisões, entre outros.
} 
academias flanando pela orla e ainda, de uma região abençoada pelos braços abertos do Cristo Redentor, cartão postal da localidade, que do topo do morro do Corcovado é avistado por quase toda a cidade. Locais turísticos como: o estádio Mário Filho - Maracanã; o Morro da Urca e o bondinho que dá acesso ao Pão de Açúcar (Figura 5); os Arcos do Teles, na Lapa; a Praça da Apoteose, no Sambódromo; as famosas praias dos bairros da Zona Sul - Leme, Copacabana, Arpoador, Ipanema e Leblon -, a topografia das montanhas, que formam o Maciço da Tijuca, contracenando com a cidade, o trabalho desenvolvido pelo paisagista Burle Marx, ou pelo arquiteto Oscar Niemeyer, que contribuíram para o embelezamento urbano e a modernização dos nossos espaços, são alguns dos exemplos usados como inspiração pelo campo joalheiro, para a produção de objetos que também se comunicam com esse imaginário social.

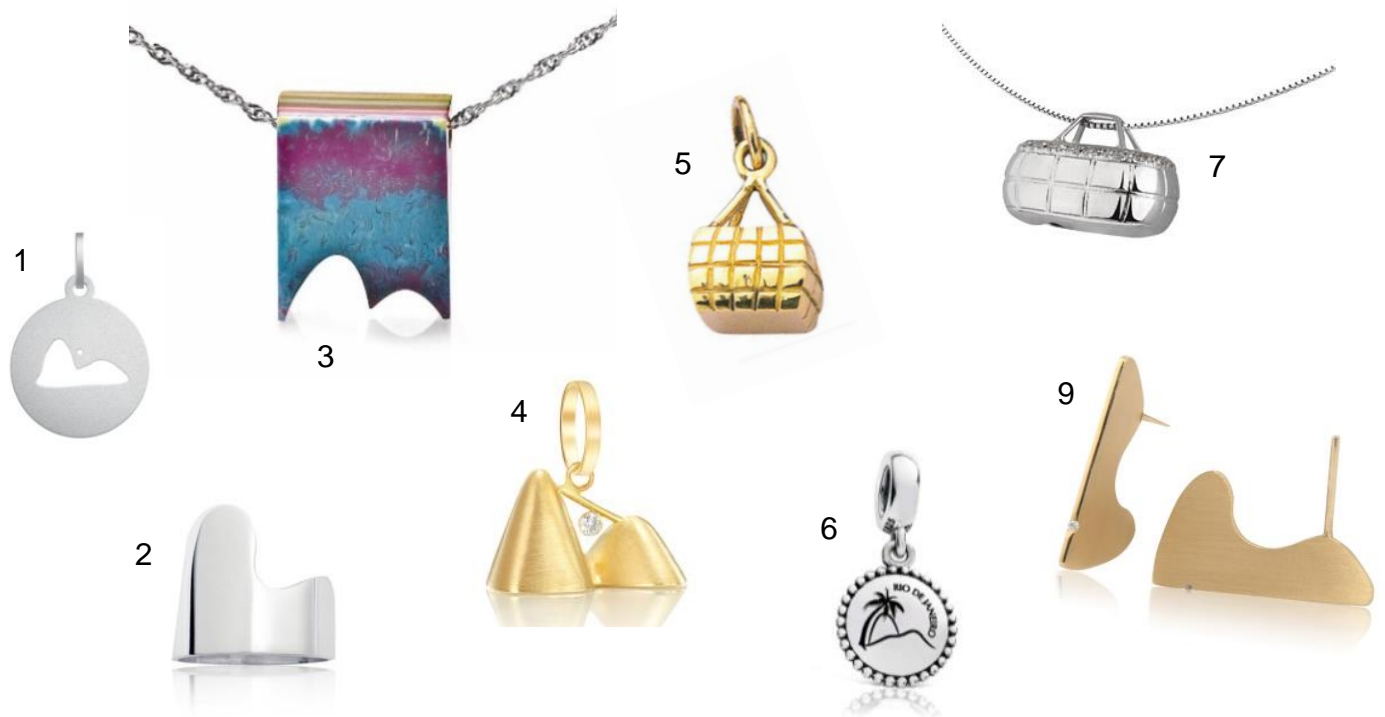

Figura 5 - Inspiração: Morro da Urca e o bondinho do Pão de Açúcar.

1. Pendente em prata Vanessa Robert; 2. Anel em prata Pablo Lozano; 3. Pendente em resina colorida Sobral; 4. Pendente em ouro amarelo com brilhante Atelier Schiper; 5 . Pendente em ouro amarelo Atelier Schiper; 6. Pendente em prata esmaltada Pandora; 7. Pendente em prata Eduarda Rodini; 8. Brinco em ouro amarelo Pablo Lozano.

As joias que representam o Rio de Janeiro e reproduzem suas formas geográficas de modo literal (Figura 6) são, em geral, mercadorias comercializadas como suvenires para turistas nacionais e estrangeiros, que durante sua estadia na cidade adquirem "mimos" para consumo próprio ou presentear amigos e familiares. Neste caso, diversos tipos de materiais podem ser utilizados na confecção das joias, indo das gemas coloridas e metais preciosos aos ditos não convencionais, como o couro, a resina epóxi e a de 
poliéster, ou o acrílico, e ficando a cargo do encantamento do consumidor pelo objeto, definir sua escolha de acordo com a qualidade apresentada versus 0 valor que está disposto a desembolsar pelas lembranças.

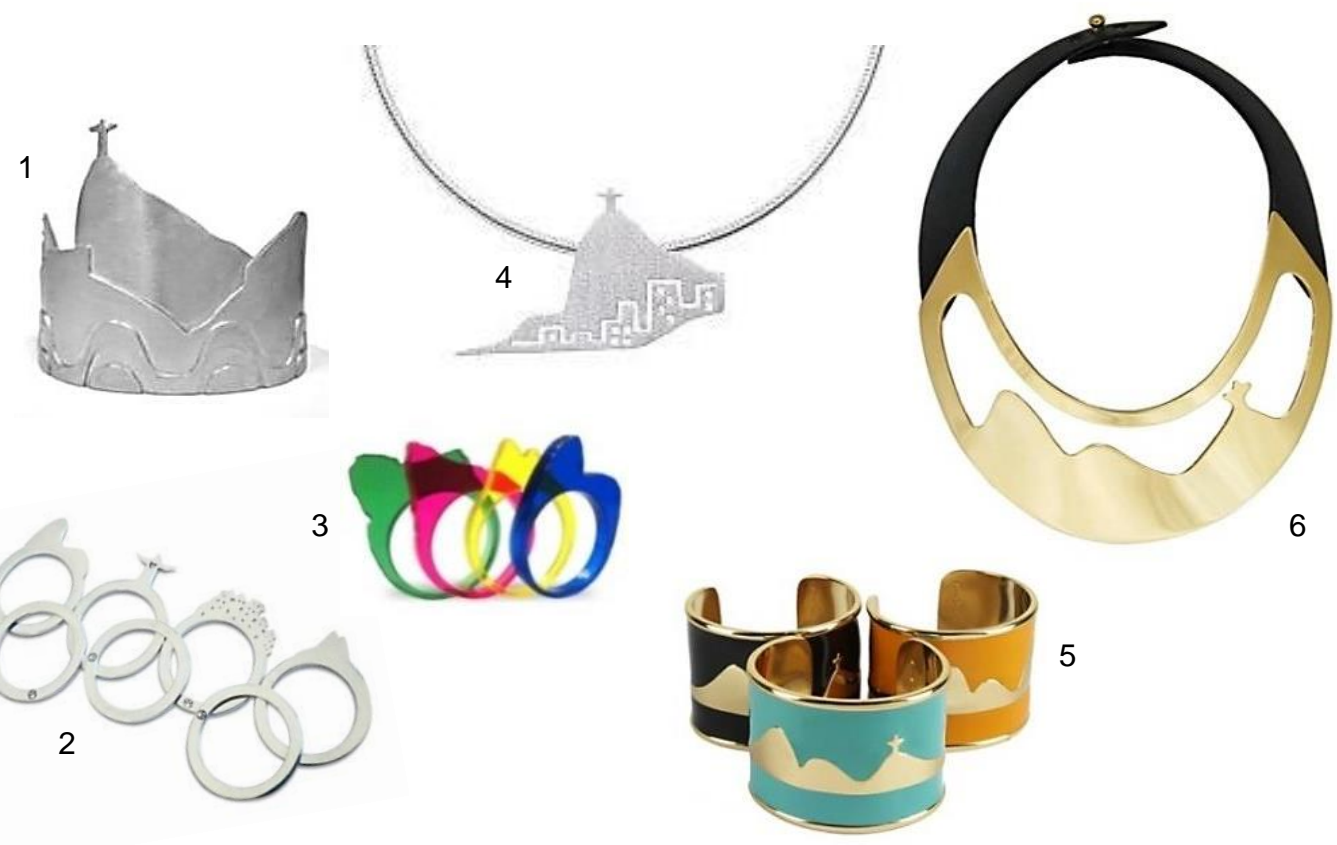

Figura 6 - Inspiração: Topografia do Rio de Janeiro.

1. Pulseira em prata Tatiana Bravo; 2. Conjunto de anéis em prata Pablo Lozano; 3. Conjunto de anéis em acrílico colorido Tupinikingdom; 4. Pendente em prata Uber47; 5. Pulseiras com banho de ouro amarelo e aplicação de esmalte colorido, Francesca Romana Diana; 6. Colar com banho de ouro amarelo e couro, Francesca Romana Diana.

Além disso, podemos observar que alguns desses significantes, elementos tangíveis explorados por esse comércio de lembranças, que nem sempre gosta de rotulá-los como suvenir, podem carregar vários significados como o Cristo Redentor (Figura 7), que é reconhecido como um ícone importante para o turismo na cidade do Rio de Janeiro, representando o Brasil no exterior, como também é o símbolo utilizado pelos praticantes do catolicismo. Neste caso, verificamos que para um público consumidor específico, muitas vezes ele não é comercializado apenas como um suvenir e sim, como um objeto sagrado ou amuleto de sorte e proteção, um signo de representação da religiosidade de uma determinada comunidade. 


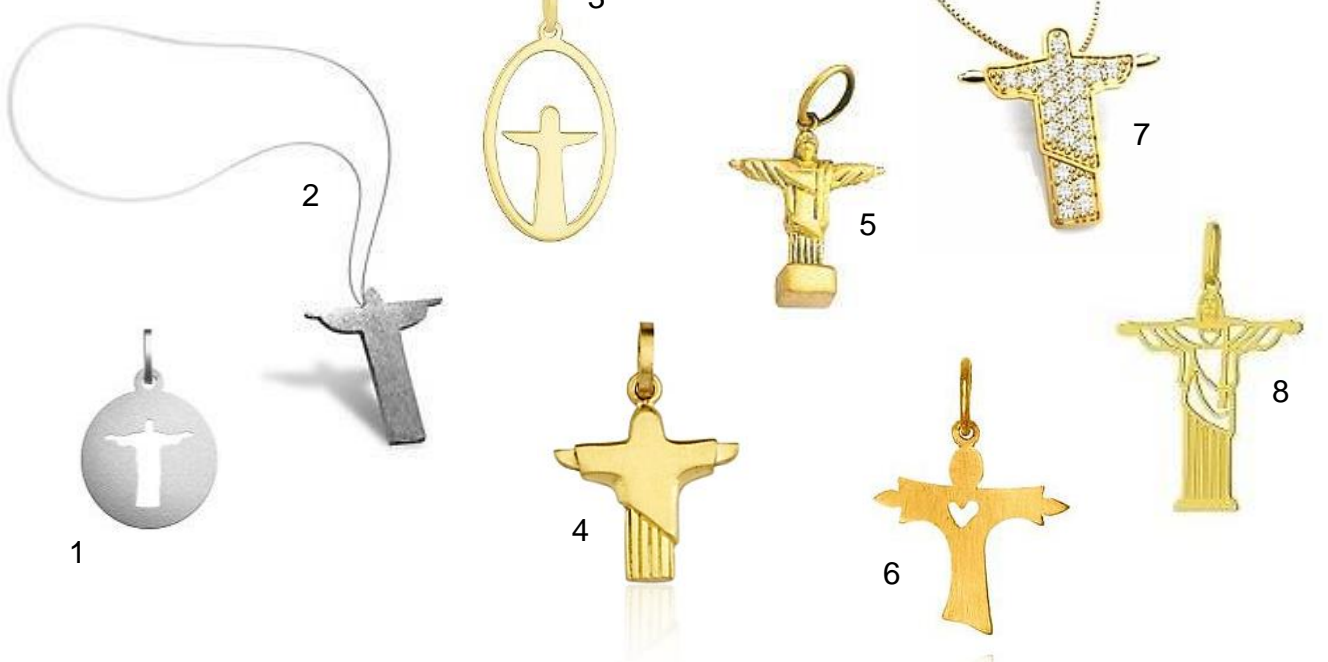

Figura 7 - Inspiração: Cristo Redentor.

1. Pendente em prata Vanessa Robert; 2. Colar em prata Ateliê Carioca; 3. Pendente em ouro amarelo Lulean Joias; 4. Pendente em ouro amarelo Lafry; 5. Pendente em ouro amarelo Atelier Schiper; 6 . Pendente em ouro amarelo Walmart, online; 7. Colar em ouro amarelo com brilhantes, vendedor não identificado, Mercado Livre, online; 8. Pendente em ouro amarelo, Joias Gold.

Há que se considerar, portanto, que existe uma inteligência ou intencionalidade nos projetos desses objetos realizados por essa categoria profissional, pois conseguem concretizar noções simbólicas abstratas sofisticadas e cruzá-las entre si. Explorando outros caminhos e buscando novas inspirações, se assim podemos dizer, temos os elementos eleitos para traduzir o famoso lifestyle carioca, que criados a partir da necessidade de consumo da própria sociedade, visam transmitir seus valores culturais e sociais para indivíduos de outros grupos (CIPINIUK, 2014, p. 35). Caipirinha, água de coco, biscoito Globo, Matte Leão, biquíni de lacinho, prancha de surf, óculos de sol, uma bike ou mesmo a padronagem formada pelas pedras portuguesas no calçadão da praia de Copacabana, são alguns dos símbolos tangíveis (Figura 8), reconhecidos e utilizados para a criação de joias que visam estabelecer uma conexão com o estilo de vida praticado na cidade. Essas peças, que além de ajudarem a compor outra categoria de suvenires, a dos elementos que fazem parte do cotidiano carioca e que têm sua utilização aceita pelos próprios moradores locais, chamando atenção para a periodicidade do aparecimento de novos ícones e, com isso, estimulando o desenvolvimento de novos produtos que e compartilham dessa mesma filosofia, movimentando o mercado. 

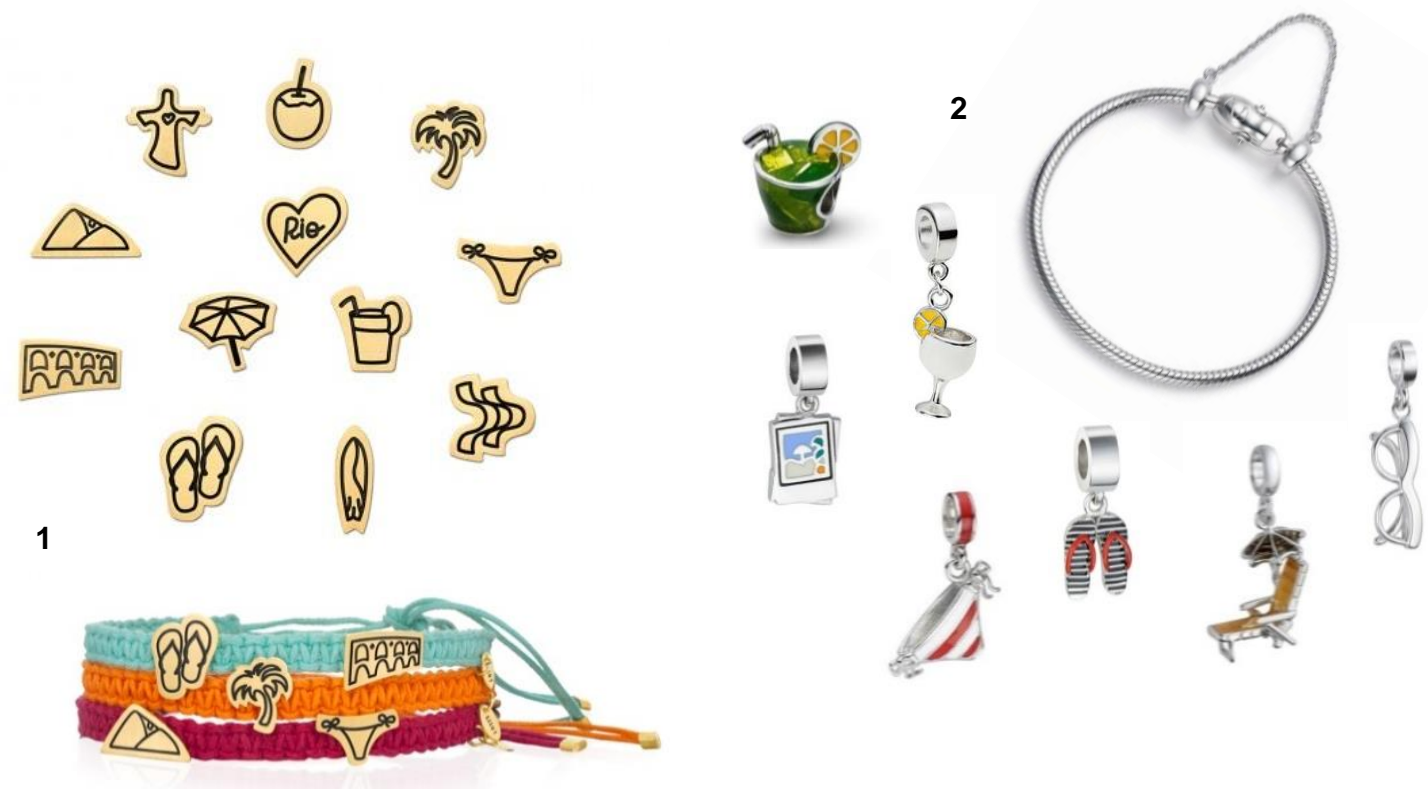

Figura 8 - Inspiração: Lifestyle carioca.

1. Pendentes em ouro amarelo com esmalte e pulseiras de algodão encerado colorido com ponteiras de ouro, Lisht para a campanha: Rio, eu amo, eu cuido (2012); 2. Pulseira e pendentes em prata com esmalte colorido, Linha Life, Vivara.

Ainda sobre esse assunto, devemos esclarecer que esse lifestyle o qual nos referimos, foi construído levando em consideração os hábitos de uma privilegiada parcela da população carioca que vive nos bairros litorâneos, ou em seus arredores, de classe média à alta, que possuem uma certa condição financeira e por isso, aparentemente, não passam por necessidades comuns vividas pela maioria dos cidadãos, como a falta de um atendimento médico adequado ou a ausência de transporte público de qualidade. Podemos observar que através do uso dessas joias, o papel social do design cumpre a sua função, ao incluir no grupo dos praticantes do lifestyle carioca os indivíduos excluídos, mas que, de alguma forma, desejam pertencer a esse universo. Estar sempre de bem com a vida, fazer muitos amigos, torcer pelo Flamengo, gostar de samba, frequentar academias, aplaudir o pôr-do-sol... E quem não gostaria de viver assim no Rio de Janeiro?

Verifica-se também que mesmo a pobreza e a miséria são tomados como elementos simbólicos para constituírem esse universo mágico e com isso incrementar vendas. Veja-se o caso das favelas, das crianças de rua, enfim de todas as mazelas que a cidade traz consigo e que de certo modo são silenciadas quando tomam formas "artísticas" em suas configurações de mercadoria para consumo (Figura 9). Novamente, verifica-se uma inteligência dos produtores 
(designers de joias) para "glamourizar" a miséria e transformá-la em produto. Tudo pode ser objeto desse tipo de conversão ou ressignificação.
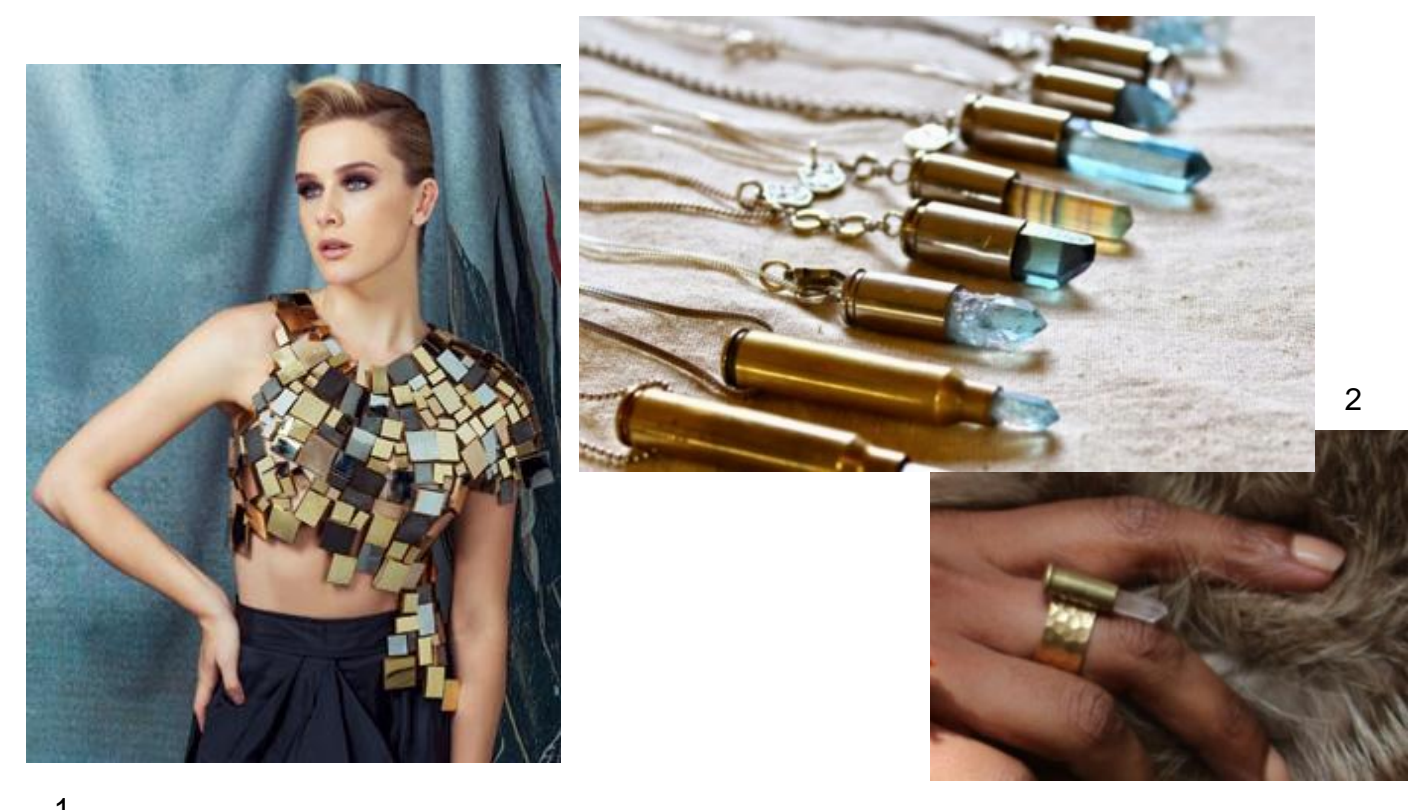

Figura 9 - Inspiração: Pobreza e miséria, o outro lado da cidade.

1. Favela T-Shirt peça em madeira e ouro amarelo, vermelho, negro e branco, Camila Schmitt, joia finalista do concurso AuDITIONS Brasil 2015; Coleção Crystals not Pistols, colares e anel com cápsulas de revólver e cristais brutos - fluorita, ametista, citrino, pirita, ágata, quartzo incolor ou aqua aura - Mars da Favela.

Em uma tentativa de fugir do convencional e das formas que já foram bastante exploradas, algumas empresas e designers autônomos investem na criação de coleções baseadas na vida e obra de personalidades brasileiras (Figura 10), que para eles, possuem alguma relevância no cenário carioca e nacional. Coleções inspiradas no músico Carlinhos Brown, nas formas do mobiliário dos irmãos Campana ou na arquitetura de Oscar Niemeyer foram criadas pela H. Stern, enquanto a obra de Portinari e Vinicius de Moraes, por exemplo, pela Amsterdam Sauer, que licenciaram os direitos de uso e exploração de imagem e obras de seus eleitos. Sobre o trabalho desenvolvido pelos designers autônomos, verificamos que na grande maioria dos casos, as coleções são desenvolvidas sem as devidas autorizações, e mesmo correndo o risco de serem punidos por apropriação indevida da imagem alheia, o fazem, divulgam e comercializam. 

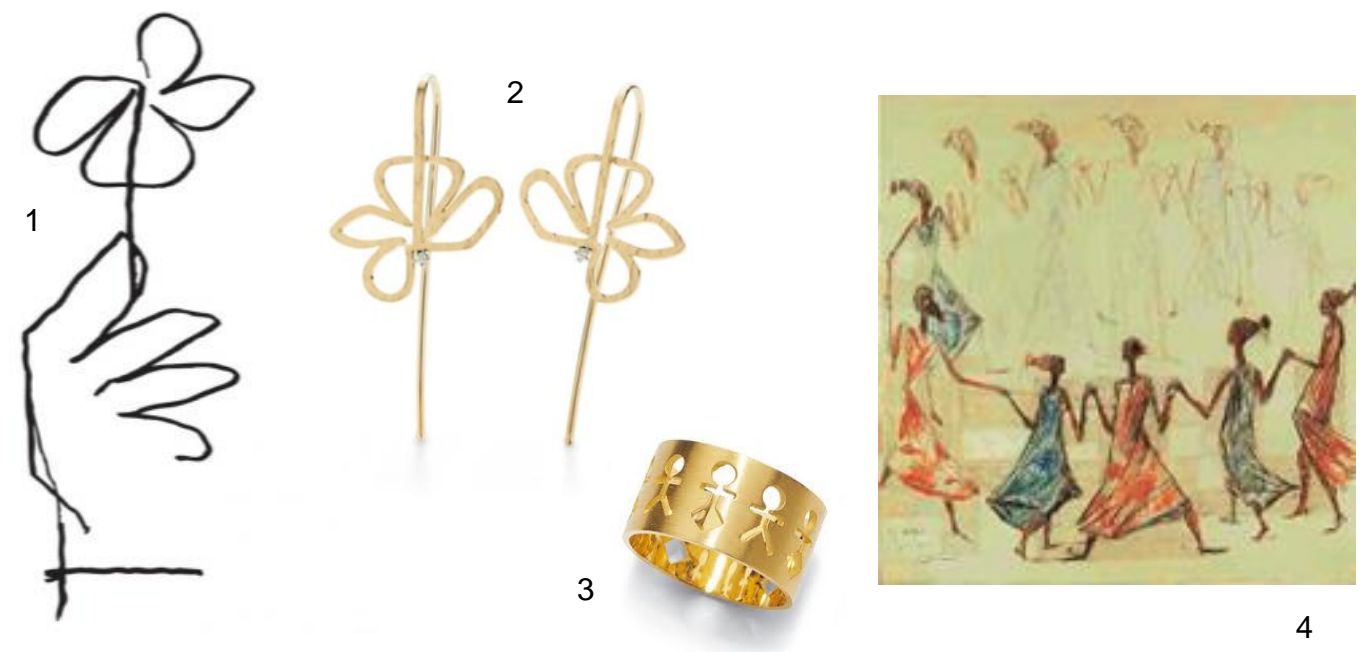

Figura 10 - Inspiração: Vida e obra de personalidades brasileiras.

1. Flor, desenho de Niemeyer; 2. Brincos em ouro amarelo e diamantes da Coleção Niemeyer H.Stern; 3. Anel em ouro amarelo da Coleção Portinari - Amsterdam Sauer; 4. Tela Dança de Roda Portinari, com a representação de uma ciranda.

Outro fato observado é que as joias que representam os elementos tangíveis como os pontos turísticos da cidade, ícones do estilo de vida carioca - biquíni, caipirinha, pranchas de surf, óculos de sol, entre outros - ou as obras de personalidades são, em sua maioria, produzidas em ouro amarelo ou branco, prata, diamantes, couro, resinas e acrílicos coloridos, fios de algodão encerados, e somente uma pequena parcela apresenta as gemas brasileiras coloridas (Figura 11) como um elemento para compor a sua forma.
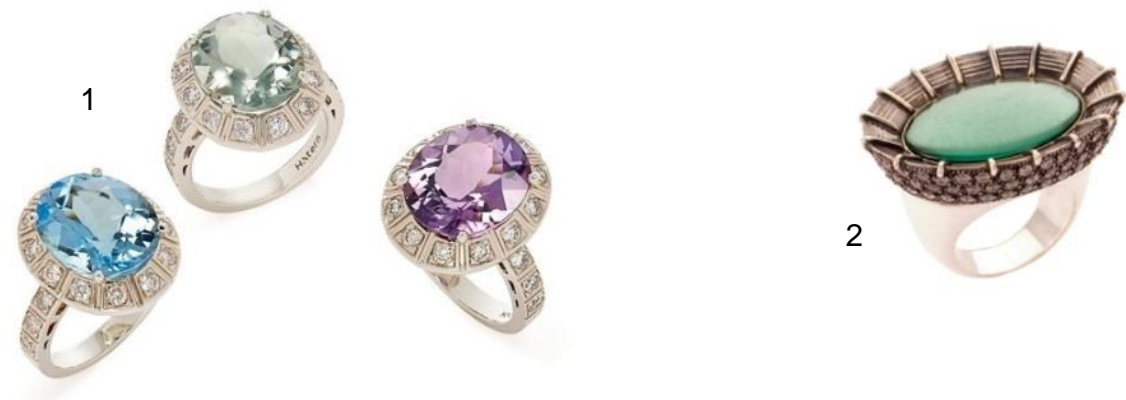

2

Figura 11 - Inspiração: Maracanã.

1. Anéis em ouro nobre com diamantes, nas versões em topázio azul, prasiolita e ametista, H.Stern; 2. Anel com material não identificado, mas que pela imagem aparenta ser em ouro branco ou prata, com banho de ródio negro na parte superior em que possui diamantes e esmeralda, Valéria Sá. 
Curioso pensar com essas gemas, tão valorizadas por consumidores ao redor do mundo e por turistas que visitam o nosso estado, não tenham o seu potencial explorado junto às peças para representar o Rio de Janeiro. Seria pelo fato das gemas coloridas serem consideradas um elemento tradicional? E se usadas, por exemplo, representariam bem as características do lifestyle carioca?

Segundo a classificação apresentada por Cipiniuk em sua obra: Design, O livro dos Porquês (2014), os objetos criados e comercializados pelo do campo joalheiro do Rio de Janeiro podem ser analisados mediante: i) aos sentimentos de encantamento e admiração que despertam sobre seu espectador ou, ii) em relação à sua funcionalidade dentro do contexto pelo qual foram projetados. Os carismáticos, pertencentes ao primeiro grupo, são aqueles objetos que possuem "algo de especial" que não pode ser verbalizado e sim sentido, afetando os indivíduos de formas e intensidades diferentes, despertando o desejo e a prática de consumos sobre os mais variados estilos de produtos. Digamos que, no campo da joalheria, são representados pelas joias, ou mais especificamente, "a joia" com a qual o consumidor se identifica, e mesmo não apresentando um motivo racional, nutre a necessidade de possui-la. Um argumento de venda comumente empregado na negociação de joias, que contém pedras preciosas, por exemplo, é falar que o dono da joia é escolhido por "tal pedra" e assim, temos uma suposta explicação para tal encantamento. Já no segundo caso, encontramos os objetos funcionalistas, e como o próprio nome já indica, são projetados para desempenhar uma determinada função, e neste caso, se enquadram as joias criadas para celebrar ritos de passagem, como as tradicionais alianças de casamento, que cumprem a função simbólica de representar um compromisso firmado entre duas pessoas; relógios em ouro com diamantes, que no quesito joia de luxo passam a ser mais do que um instrumento com função de medir o tempo; anéis "inteligentes" (Figura 12) com a função de comunicação com outros aparelhos eletrônicos, relógio, abridor de garrafas, compartimento embutidos para carregar um remédio; pulseiras que auxiliam no desempenho dos exercícios físicos com a função de medir os batimentos cardíacos ou a quantidade de calorias gastas durante um treino. Porém, esse requisito de "funcionalidade" só é aplicado a um grupo muito restrito de objetos produzidos pelo campo, ficando assim, a grande maioria das joias, reconhecidas como carismáticas. 

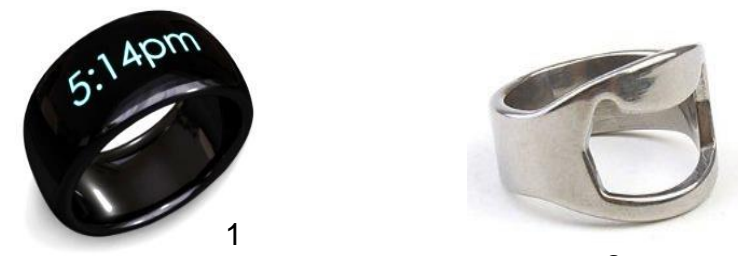

2

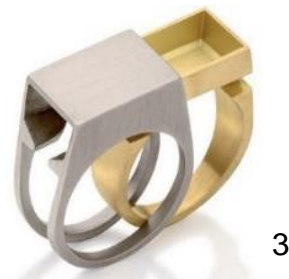

Figura 12 - Anéis que desempenham alguma função específica.

Em sentido horário: SmartRing recebe notificações de textos, e-mails, mensagens e ainda acessa o Facebook e Twitter, da MOTA; Anel abridor de garrafas comercializado pelo site Aliexpress; Anel Mr. Chapman's Secret de Antônio Bernado.

Objetos de arte ou objetos industriais são carismáticos na medida em que se relacionam com os indivíduos e os seduzem. Porém, no caso dos objetos industriais, podemos agregar a funcionalidade como um aspecto simbólico, na medida em que seguem uma metodologia de projeto para a sua execução. As questões que envolvem a configuração estética dos produtos, que na esfera carismática e para os objetos de arte não são propriamente gratuitas, e por conta de sua localização temporal na sociedade industrial, sofrendo os efeitos do modo de produção capitalista, passarão a ser mais uma das características na lista de requisitos atendidos pelo ato de projetar. Sendo assim, podemos considerar que mesmo as joias produzidas em série, para atender um determinado objetivo funcional, como o de representar abridores de garrafas, marcadores de batimentos cardíacos ou qualquer outra bobagem industrial com um sentido utilitário e que eventualmente imbricam-se com o Rio de Janeiro, precisam mesclar sentimentos (que fazem parte de uma dimensão simbólica) e funcionalidade para serem percebidas, desejadas e consumidas pela sociedade.

Atualmente as joias que expostas nas vitrines das joalherias ou nos ateliês dos designers autônomos e que fazem referência ao Rio de Janeiro são, em sua grande maioria, produzidas em ouro ou prata, com ou sem a utilização de gemas coradas e diamantes, e independente do emprego de materiais complementares, com o couro entre outros já citados, possuem como motivo principal de inspiração os pontos turísticos e as belezas naturais da cidade; o lifestyle carioca; ou ainda, a vida e obra de alguma personalidade. Porém, nem todas as joias que foram criadas dentro dessa temática, e estão sendo comercializadas, passaram pelas mãos de designers especializados em desenvolver produtos para atender as necessidades do campo joalheiro. Sendo assim, podemos 
verificar que são poucos os casos em que uma nova peça criada para representar um dos pontos turísticos da cidade, por exemplo, apresenta esse aspecto que estávamos comentando mais acima e que normalmente são a base das denominadas discussões teóricas entre os pares do campo, enfim isso que denominam de "uma releitura diferenciada" e "inovadora", de tudo o que já foi apresentado. Enfim, de acordo com aquilo que pudemos verificar concretamente, esses debates são vazios e não levam a lugar algum.

Forty em Objeto de Desejo (2013), ao citar Wally Olins, que em seu livro: The Corporate Personality apresenta o design como uma ferramenta eficaz e reconhecida pelas organizações (empresas) na tarefa de construção e divulgação de sua identidade funcional, se conectando internamente com seus funcionários e externamente se expressando para o mundo empregando uma configuração estética, isto é, concretizando noções abstratas que se associem às empresas, por intermédio de algumas formas padronizadas e concretizadas em uniformes, símbolos distintivos arbitrados como materialização da empresa, cores, etc. Esse é mais um dos indícios que aprovam ou justificam o papel do designer dentro das organizações, e poderia ser tomado como exemplo pelas empresas que compõe o campo joalheiro no Rio de Janeiro. Apostar no trabalho dos designers é o mesmo que oxigenar o campo com novas ideias e, por consequência, apresentar novas opções de joias ao mercado consumidor, mas como tudo na vida tem um custo, e para isso se tornar realidade, vai depender da vontade e do investimento de capital humano e financeiro disponibilizado pelas empresas, poucas são as empresas preocupadas em investir em uma marca ou identidade dos seus produtos, assim como tudo que pode se associar a elas.

No caso do Rio de Janeiro, no caso do designer autônomo, trabalhar seguindo uma metodologia de projeto já faz parte do seu processo de desenvolvimento de produtos, por essa razão, suas joias, criadas e comercializadas, podem ser consideradas, em alguns casos, como as mais criativas ou "diferentes". As empresas que não possuem uma equipe de criação, própria ou terceirizada, geralmente reproduzem ideias já consagradas por outras joalherias e aceitas pelos consumidores, ou abastecem seus estoques com peças de fornecedores, que também atendem os seus concorrentes e com isso, e por não comprarem com exclusividade, correm o risco de divulgarem as mesmas joias, mas com preços diferenciados dos praticados pela joalheria logo ao lado. 
A revista Vogue Brasil (1975), um importante veículo de divulgação, mas também um prestigioso instrumento de legitimação de valores simbólicos, quando ainda era editada a Vogue Joias $(2002-2007)^{68}$, publicou no ano de 2005 uma matéria com o título: Viaje pelas joias do Brasil, e na sessão dedicada ao Rio de Janeiro, ressaltava: que além do mar temos montanhas, com Petrópolis a cidade imperial; que além do samba temos de Rock in Rio a Tom Jobim e Vinicius de Moraes... "É a vitrine de nossas joias e gemas para o mundo, cor, valor, graça, criatividade, formas e jeito carioca, dança graciosa das pedras brasileiras". Sendo assim, retomando ao assunto dos objetos e o "conceito" construído, ou o arbitrário cultural construído no campo joalheiro do Rio de Janeiro podemos verificar a partir do discurso de legitimação simbólica publicado pela revista, que nada mudou, e o que se apresenta ainda hoje é resultado de um processo longo de inculcação, no qual, durante muito tempo, os agentes que dominaram o campo ${ }^{69}$, ditaram regras, e em benefício próprio, as legitimaram ou consagraram, como verdades únicas e absolutas.

Atualmente, em oposição a essas noções, encontramos um grupo formado por novos empreendedores, designers e joalheiros autônomos, que aos poucos vêm conquistando seu espaço, e assim, através de suas peças, do uso de novos materiais e novas tecnologias, buscam apresentar uma crítica às antigas regras impostas pelo campo, provocando uma ruptura intencional com tudo o que já foi praticado por ele, dentro dele e para ele. Um novo pensamento e por consequência, um novo "conceito", um novo arbitrário cultural para ser desenvolvido em seus produtos, é o que o grupo deseja, mas que ainda não tem as diretrizes definidas de como ou por onde começar a agir. Essa é apenas uma das discussões que poderão gerar uma revolução de ideias e atitudes dentro do campo. Podemos com isso concluir que para esse grupo, o objeto ou mesmos uma coleção que represente o Rio de Janeiro deve ser, e também representar, muito mais do que até hoje já foi apresentado.

A definição deste "novo" arbitrário cultural vai requerer mudanças e estas deverão começar internamente pelas etapas de criação e produção, envolvendo a seguir novas estratégias de divulgação e a comercialização, como também a participação de todos os profissionais do campo interessados em contribuir para o desafio. Não podemos esquecer de que no campo joalheiro as mudanças

\footnotetext{
${ }^{68}$ Não foram encontrados dados precisos sobre o período do início e término da publicação especial Vogue Joias. As datas apresentadas foram coletadas dos exemplares da própria autora. 69 Joalherias familiares.
} 
acontecem lentamente e demoram a passar, embora o marketing, o mundo das tendências e da moda queiram nos vender transformações velozes, como o fast fashion $^{70}$, no qual as mercadorias produzidas são consumidas e descartadas da noite para o dia. Criar e fabricar, ou mesmo copiar uma joia vai requer muito mais tempo e investimento em matéria-prima, ferramentas e mão de obra especializada se comparada a este tipo de indústria de moda.

Como falar de Rio de Janeiro sem apresentar seus pontos turísticos mundialmente conhecidos, sem o formato de suas montanhas e a beleza natural de suas praias, ou ainda, sem mencionar a paixão pelo futebol e o batuque perfeito do samba embalada pelas curvas das mulatas... Como ignorar essas referências simbólicas construídas e consolidadas ao longo de anos por nossa sociedade? Talvez a ideia de se estabelecer um novo "conceito" não seja o melhor caminho, ou mesmo inviável. Quem sabe uma "nova abordagem", um olhar diferenciado sobre os conceitos já existentes, de modo que eles englobem novas visões sobre a cidade, por exemplo, ou ainda, apostar mais no uso das gemas coloridas brasileiras para a ampliação do leque desses produtos, pois conforme apresentam as imagens selecionadas para esse capítulo, estas gemas são pouco exploradas pelas peças que carregam o "conceito" construído e legitimado pelo campo joalheiro do Rio de Janeiro. Essas e muitas outras questões buscam por uma resposta, estão em pauta para serem pensadas pelo campo e pela nova geração de designers de joias e profissionais que por ele, por ventura, venham a se encantar.

\section{2}

\section{As instituições de legitimação do campo joalheiro do Rio de Janeiro}

As instâncias de legitimação, segundo Bourdieu (2013, p.106) são os espaços de circulação habitados por pares, que pertencentes ao mesmo grupo e se reconhecem, promovendo assim, a sua consagração. Dotados pelo status de autoridade, esse grupo exerce o seu poder ao determinar o que deve ou não ser considerado pelo meio e desta forma, tece uma grande rede de relacionamentos voltada para atender as necessidades de seus eleitos, excluindo aqueles que, de alguma forma, não se moldam aos seus padrões.

\footnotetext{
${ }^{70}$ Fast fashion - termo em inglês que significa: "moda rápida".
} 
No campo joalheiro, essas instâncias são representadas pelas joalherias, pelas entidades formadas por membros do setor e pelo setor, pelos espaços de divulgação, como as feiras, pelas instituições de ensino e pelos designers atuantes no mercado.

O campo joalheiro no Rio de Janeiro foi, por muito tempo, um espaço de uso restrito de empresas familiares - joalherias e pequenos fabricantes -, que aqui fundaram suas companhias, dominaram o mercado e assim, detinham a função de criação e desenvolvimento das joias que representavam o estado. Devemos também, ressaltar a presença de alguns artistas plásticos como Caio Mourão ${ }^{71}$, por exemplo, que de forma autoral desenvolveram seus trabalhos em ateliês particulares espalhados pela cidade, onde atendiam aos consumidores que buscavam por peças exclusivas e fora dos padrões de estilo e matéria-prima oferecidos pelas joalherias tradicionais.

As joalherias escolhidas para representar as empresas do campo joalheiro, são as também mais importantes, devido à sua tradição, atuação e reconhecimento no mercado nacional e internacional. Dentro deste contexto, jamais podemos pensar no setor sem considerar a presença da Amsterdam Sauer e da H.Stern, duas grandes joalherias, em atividade até os dias de hoje e que fizeram história no Rio de Janeiro. Ambas fundadas por imigrantes europeus, que ao fugirem dos horrores da $2^{\text {a }}$ Guerra Mundial (1939-1945), desembarcaram no Brasil, e por acaso do destino se encantaram pelo colorido das gemas coradas encontradas em abundância no solo nacional.

\section{A joalheria Amsterdam Sauer}

A joalheria Amsterdam Sauer foi fundada pelo francês Jules Roger Sauer, nascido em 1921, na região da Alsácia, em uma família de classe média. Foi um menino estudioso, aplicado e interessado em assunto que envolvia política e geografia. Planejava conhecer o mudo, porém o destino bateu a sua porta e aos 18 anos de idade foi obrigado a fugir, quando a Bélgica fora invadida pelas tropas comandadas por Hitler.

Jules ainda estava na escola quando recebeu a notícia da invasão e aconselhado por um professor que voltasse para casa e se recolhesse junto a sua família, o jovem, que tinha uma visão realista sobre os fatos que estavam

\footnotetext{
${ }^{71}$ Para saber mais sobre Caio Mourão e sua obra, consulte o site do Atelier Mourão. Disponível em: < http://www.ateliermourao.com.br/caio_mourao.html >. Acesso em: 29 de dezembro de 2016.
} 
acontecendo naquele momento e do perigo eminente que se abatia sobre ele ou qualquer outro judeu com a disseminação do nazismo, em um ato impulsivo, pegou sua bicicleta e pedalou o mais distante que pode, com o intuito de ficar o mais longe possível das tropas do general nazista. Atravessou a França e chegou à Espanha, onde foi detido por não apresentar documentação. Escapou e dali partiu para Portugal, onde permaneceu e trabalhou durante as madrugadas para se proteger da fiscalização, até o dia em que tomou conhecimento da notícia de que um navio partiria em breve para a América do Sul.

Poliglota, o jovem falava alemão, pois era a língua praticada em casa; o francês, que era o idioma da Antuérpia onde morava com a família; o espanhol e o inglês que foram ensinados na escola, e assim, não teve dificuldades em convencer o comandante do navio a aceitar seus serviços, durante a longa viagem que reuniria milhares de pessoas de diversas nacionalidades, em troca da passagem rumo à Argentina. Antes de chegar ao seu destino final, na última parada de abastecimento do navio, no Rio de Janeiro, e mesmo sem informação sobre o lugar, mas atraído pela alegria do povo local, pelo clima quente e pela exuberância da natureza, Jules resolveu ficar e apostar o seu futuro neste país.

De ajudante de fotógrafo a professor particular de francês, Jules fez de tudo até receber uma proposta e se mudar para Minas Gerais, onde foi trabalhar com o comércio de pedras preciosas. Dedicado e competente, começou como consultor de qualidade, aprendeu o ofício da lapidação de gemas chegando ao cargo de gerente da empresa. Conquistou a confiança do chefe, que aos poucos deixou o comando do negócio em suas mãos. O trabalho era tudo na vida do jovem francês. Sempre em busca de uma oportunidade, uma pedra rara ou uma negociação milionária, não demorou muito para Jules, que dominava todo o processo, do garimpo à lapidação das gemas, começasse a receber o retorno financeiro de tanto empenho e assim, no ano de 1941, abriu seu primeiro negócio - Lapidação Amsterdam Limitada ${ }^{72}$ - com sede em Belo Horizonte.

A empresa cresceu e em pouco tempo se transformou em uma importante companhia no comércio de pedras preciosas no Brasil, que oferecia seus serviços desde a mineração, lapidação, compra e vendas por atacado de gemas coloridas e de alta qualidade. O jovem visionário, sem qualquer noção de administração, precisou de ajuda para organizar as finanças da empresa, e em

\footnotetext{
72 Localizada na Rua Tiradentes, 25. Belo Horizonte, Minas Gerais.
} 
1943, contrata Zilda Waks para o cargo de secretária. Em 1947, após patronizar o trabalho da Lapidação Amsterdam Ltda., ela se torna sócia de Jules e três anos mais tarde, sua esposa.

Com a estagnação dos negócios em Belo Horizonte, Jules resolve mudar para o Rio de Janeiro, que na época abrigava a sede da República. Aluga um espaço no Centro do $\mathrm{Rio}^{73}$ e para atender a demanda crescente por joias requisitadas pelo público feminino e por turistas estrangeiros em visita ao país, transforma o que antes era um escritório que comercializava pedras precisas em uma joalheria de prestígio, vindo a ser reconhecido pela qualidade e variedade de joias em ouro recheadas com pedras preciosas lapidadas em grandes dimensões, principalmente com águas-marinhas, turmalinas, topázios imperiais, ametistas e citrinos. Inicialmente chamada de Sauer, a primeira loja de varejo foi inaugurada em $1956^{74}$, no térreo do Edifício Chopin, ao lado do famoso Hotel Copacabana Palace, na Avenida Atlântica, considerado um dos pontos mais chiques da Zona Sul do Rio de Janeiro. Já a segunda loja veio no início da década de 1960, estrategicamente localizada na Avenida Rio Branco, por concentrar o centro financeiro e comercial da capital na época. Muita coisa mudou desde então, porém, as duas lojas existem até hoje e nos mesmos locais... E com a fusão das duas empresas - Lapidação Amsterdam Ltda. e Sauer, Joalheiros Creadores ${ }^{75}$ - o negócio que englobava deve a prospecção das pedras a vendas no varejo, passou a se chamar Amsterdam Sauer, como atualmente conhecemos.

Jules Sauer tem uma importante ligação com a descoberta e divulgação das esmeraldas brasileiras para o mundo. É atribuída a ele a histórica certificação conferida pelo GIA - Instituto Gemológico Americano - para as esmeraldas da mima de Salininha. Com o seu feito, o Brasil passou a ser reconhecido mundialmente com um polo produtor de esmeraldas e esse foi um marco histórico e importante para o comércio brasileiro de gemas. Movido pela paixão por pedras preciosas, em 1989, a coleção garimpada por Jules ao logo da vida, foi organizada em um espaço - Museu Amsterdam Sauer ${ }^{76}$ - com o objetivo de registrar e valorizar a memória gemológica do país, oferecer ao público a oportunidade única de apreciar exemplares raríssimos e de alta qualidade, como

\footnotetext{
${ }^{73}$ Conjunto de salas localizadas na Rua México, 41. Centro. Rio de Janeiro.

74 Loja localizada na Avenida Atlântica, 1782. Disponível em:< http://amsterdamsauer.com.br/ocacador-de-pedras-raras/ Acesso em: 02 de outubro de 2015.

${ }^{75}$ Creadores - a grafia da palavra é apresentada de acordo com as regras gramaticais da época (1960) e está presente nos registros históricos da empresa.

${ }^{76}$ Rua Garcia D’Ávila, 105. Ipanema. CEP: 22421.010. Rio de Janeiro.
} 
por exemplo, um topázio transparente de 68k, que fora registrado no Guinness Book $^{77}$ como um dos maiores do mundo.

Comemorando seus 76 anos de existência, em 2016, a empresa que já passou pelas mãos dos filhos - Debora e Daniel Sauer -, agora recebe em sua administração a terceira geração da família ${ }^{78}$, vivência muitas transformações com a revitalização e modernização de sua imagem, apresentando joias com formas mais ousadas, porém preservando a identidade conquistada por seu fundador, as pedras preciosas.

"Pedras preciosas: uma colheita que jamais se repete"79.

JULES SAUER

\section{A joalheria H.Stern}

A joalheria H.Stern foi fundada pelo alemão Hans Stern (1922-2007) em 1945, no Rio de Janeiro, e no presente, ocupa um lugar de destaque no varejo entre as empresas de bens de consumo de luxo no Brasil e no mundo. É a única marca brasileira que participa do relatório Global Powers of Luxury Goods ${ }^{80}$, da Deloitte $^{81}$, e dentro de um rol composto por 100 empresas, em 2015, ocupou a 94a posição do ranking que analisa as gigantes de luxo em relação à receita apresentada e volume de vendas anual.

A história desse império inicia às vésperas da Segunda Guerra Mundial, em 1939, quando a família Stern, também fugindo do nazismo e em busca de uma terra de paz e novas oportunidades, decide trocar Essen, cidade industrial na Alemanha, pelo Brasil, e com a ajuda da família do paisagista brasileiro Roberto Burle Marx, se instalam na cidade do Rio de Janeiro. Nesse momento, Hans aos 17 anos de idade inicia sua vida profissional em uma casa filatélica, para ajudar nas despesas de sua família. Coincidências a parte, colecionar e estudar selos eram o seu hobby, e assim, com conhecimento de causa ele começou a ganhar

\footnotetext{
77 Livro dos recordes.

${ }^{78}$ Rafael Eisenberg, filho de Debora Sauer, Gabriel Andre Sauer, filho de Daniel Sauer e a sua enteada, Stephanie Wenk.

${ }^{79} \mathrm{O}$ caçador de pedras preciosas. Disponível em:< http://amsterdamsauer.com.br/o-cacador-depedras-raras/ >. Acesso em: 28 de agosto de 2015.

${ }^{80}$ Relatório Global Powers of Luxury Goods, 2015, p.18. Para download do arquivo acesse site da Deloitte. Disponível em:< http://www2.deloitte.com/content/dam/Deloitte/ch/Documents/consumerbusiness/ch-en-cb-global-powers-of-luxury-goods-2015.pdf >. Acesso em: 30 de agosto de 2015.

81 Deloitte Touche Tohmatsu Limited (DTTL) - É uma empresa do Reino Unido que conta com a colaboração de diversos profissionais alocados em diversas empresas ao redor do mundo, onde em conjunto, oferecem serviços profissionais nas áreas de: auditoria, consultoria, assessoria financeira, gestão de risco, impostos e serviços a clientes selecionados. DELOITTE. About Deloitte. 2015. Disponível em:< http://www2.deloitte.com/ch/en/pages/about-deloitte/articles/aboutdeloitte.html?icid=bottom_about-deloitte >. Acesso em: 30 de agosto de 2015.
} 
dinheiro fazendo algo do qual gostava. Em 1941, Hans muda de emprego e como correspondente em inglês de uma empresa que lapidava e exportava pedras preciosas, cristal de rocha e mica, teve seu primeiro contato com o que mudaria de vez a sua vida, as gemas coradas brasileiras. Em suas horas de folga estudava inglês para se aperfeiçoar, pois tudo o que sabia era o que havia aprendido nos tempos de escola, ou seja, quase nada, porém um pouco mais do que o seu patrão, o que lhe foi suficiente para garantir sua contratação.

Promovido a gerente, aprendeu o ofício da lapidação e assim decidiu que havia chegado a hora de trabalhar por conta própria. Empreendedor, Hans conhecia o mercado, desde o garimpeiro ao joalheiro, possuía bons relacionamentos, e sobre tudo, entendia de pedras preciosas como ninguém. Ele viajava pelo interior do Brasil comprando e consignando pedras preciosas que eram vendidas diretamente aos joalheiros e aos exportadores do Rio de Janeiro e de São Paulo e assim, montou o seu primeiro escritório, que funcionava em uma pequena sala localizada na Rua Gonçalves Dias, no Centro do Rio. Segundo a timeline ${ }^{82}$ apresentada no site da H.Stern, naquela época, para angariar dinheiro e iniciar seu negócio, vendeu o seu acordeão $H_{o h n e r}{ }^{83}$, única lembrança preservada de quando deixou a Alemanha.

O jovem Hans nasceu cego e só começou a enxergar, com o olho direito, aos dois anos de idade e nunca não se deixou intimidar por sua deficiência visual. Apaixonado pelas gemas brasileiras e movido pela vontade de mostrar ao mundo o seu valor, foi testemunha da descoberta de pedras raríssimas como: a turmalina da Paraíba e a água-marinha da mina de Santa Maria, Minas Gerais.

Motivado pelo pedido de um amigo, que se encantara por uma de suas pedras e desejava tê-la em uma joia, Hans a produziu e logo depois montou uma oficina com dois ourives e uma lapidação com três lapidários. Observador, percebeu que as pedras brasileiras eram muito valorizadas pelos estrangeiros, e que os brasileiros, pouco manifestaram seu interesse, e assim, focou inicialmente nos turistas e abriu sua primeira loja no Hotel Quitandinha, em Petrópolis. Tão famoso quanto o Copacabana Palace, o Quitandinha foi um hotel cassino glamoroso, palco de shows inesquecíveis, no qual foram gravados os filmes da Atlântida e, na época, circulava muito dinheiro. O passo seguinte foi a instalação

\footnotetext{
82 TIME LINE H.Stern. Disponível em:< http://www.hstern.com.br/institucional/hs_timeline.aspx >. Acesso em: 30 de agosto de 2015.

${ }^{83}$ Instrumento musical, de origem alemã, que é formado por duas caixas de madeira com um fole e um diapasão.
} 
de vitrines e estandes em outros hotéis espalhando pelo Rio de Janeiro, que juntamente com a cidade Buenos Aires na Argentina, passou a compor a rota turística da América do Sul, muito procurada por estrangeiros.

Preocupada em manter o padrão de qualidade de sua principal riqueza, as pedras preciosas, a H.Stern foi a primeira joalheria a montar um laboratório gemológico de análise, identificação e certificação de gemas, na América Latina, seguindo os rigorosos padrões internacionais adotados pelo Gemmological Institute of America ${ }^{84}$ - GIA, e no final da década de 1940, lança uma campanha para divulgar a beleza das pedras coloridas brasileiras, que na época, rotuladas como semipreciosas em um universo onde apenas as pedras orientais - safiras, rubis e esmeraldas - juntamente aos diamantes figuravam entre as preciosidades. Pioneira em muitos quesitos, a empresa também criou, na década de 1950, um certificado de garantia internacional que assegura aos seus consumidores os mais rígidos padrões de qualidade da matéria-prima e dos processos de produção empregados em suas joias. Este documento, que existe até hoje, permite que o proprietário de uma peça com a sua assinatura, solicite consertos em qualquer uma das lojas da rede ${ }^{85}$, localizadas no Brasil ou em seus representantes pelo mundo afora - Alemanha, Argentina, Chica, Coreia do Sul, Estados Unidos, França, Inglaterra, Israel, México, Peru, Portugal e Rússia.

"Stern", sobrenome do fundador, que na tradução para o português significa "estrela" cresceu e se transformou em uma das assinaturas mais prestigiadas de joias produzidas com pedras brasileiras. Em 1995, a comemoração do aniversário de 50 anos da empresa foi um marco importante para a H.Stern. Com o apoio de Hans e sob o comando de seu primogênito, Roberto Stern, a empresa passou por uma planejada reestruturação interna, que resultou em um processo de reposicionamento de imagem perante o mercado e consumidores brasileiros. A inspiração para as novas criações da marca passaram a refletir o desejo e o estilo de vida de seus consumidores e o "design passou a ser tão valorizado quanto as pedras e os metais". ${ }^{86}$

Com o objetivo de conhecer melhor as operações internas da empresa e assim, contribuir de forma eficaz para o sucesso com as mudanças, Roberto Stern atuou estrategicamente em várias áreas, apostando em campanhas de

\footnotetext{
${ }^{84}$ GIA - Instituto Gemológico da América.

${ }^{85}$ Lojas da rede H.Stern em 2015. Disponível em: < http://www.hstern.com.br/servicos/lojas>. Acesso em: 25 de agosto de 2015.

${ }^{86}$ H.Stern nostalgia, p.17. Texto de Brandão elaborado para a revista Vogue H.Stern, que é parte integrante da Revista Vogue Brasil no 334. Ano 2006.
} 
marketing mais elaboradas, em novos projetos para a arquitetura de seus pontos de venda e inaugurando o conceito de coleções assinadas por nomes famosos como, por exemplo: a consultora de moda Costanza Pascolato, em 1997, e o músico percussionista Carlinhos Brown, em 1999. Depois vieram os irmãos Campana, Diana von Furstenberg, Burle Marx, Oscar Niemeyer, Carmem Miranda entre tantos projetos e parcerias bem-sucedidas da marca.

Em outubro de 2007, aos 85 anos, o fundador da H.Stern veio a falecer. ${ }^{87}$ Casado com Ruth Stern deixa um império e a princípio quatro filhos - Roberto, Ricardo, Ronaldo e Rafael. Atualmente Roberto é responsável pelas áreas de criação e inovação e Ronaldo responde pelas operações realizadas nos Estados Unidos, Caribe e México.

De Essen para o Rio de Janeiro e depois para o mundo... Hoje, ao comemorar 70 anos, as joias da H.Stern desfilam sobre o tapete vermelho durante a festa do Oscar em Hollywwod e são os objetos de desejo preferidos de tops ${ }^{88}$ internacionais com Kate Moss. Design, sofisticação e qualidade traduzidos em coleções que conquistam e seduzem cada vez mais seus consumidores. Além das joias, experiências únicas são oferecidas através da comercialização de sofisticados objetos para casa - H.Stern Home - e também de um restaurante de alta gastronomia - Eça - localizado no Centro do Rio de Janeiro, no subsolo de uma de suas lojas.

\begin{abstract}
"Idas e vindas no tempo são a alma da joalheria. Buscamos inspiração no passado, mas a interpretação tem que ser atual. Imaginamos o futuro atendo-nos às técnicas de hoje. É uma questão de viajar no tempo, de quebrar barreiras, de buscar o novo, sem esquecer nossas raízes." ${ }^{189}$
\end{abstract}

ROBERTO STERN Pela tradição no mercado, a Amsterdam Sauer e a H.Stern, são reconhecidas com as mais importantes joalherias brasileiras e foram fundadas por estrangeiros com histórias de vida parecidas. Em tempos de guerra vieram para o Brasil, um sozinho e o outro com sua família, em busca de um futuro de paz e melhores oportunidades. Aqui eles fizeram fama e fortuna com a comercialização das pedras brasileiras.

\footnotetext{
${ }^{87}$ Seu falecimento foi noticiado pela imprensa internacional. The New York Times. Hans Stern Dies at 85; Built Global Jewelry Empire. 2007. Disponível em: < http://www.nytimes.com/2007/10/29/world/americas/29stern.html?_r=0 >. Acesso em: 02 de outubro de 2015.

${ }_{88}$ Tops - abreviação de top model que traduzido para o português significa: modelo.

${ }^{89}$ H.Stern. Uma estrela de brilho eterno. Disponível em:< https://hstern.com.br/institucional/sobrehstern >. Acesso em: 28 de agosto de 2015.
} 
Com o tempo, as empresas que nasceram e cresceram juntas foram se diferenciando e se distanciando em relação aos seus objetivos. Enquanto a H.Stern voltava seus esforços para ampliar a sua gestão empresarial contratando funcionários com know-how no mercado para comandar as áreas estratégicas dentro da empresa - marketing, produção, atendimento ao cliente, pós venda, entre outras - a Amsterdam Sauer se manteve em uma gestão familiar e obsoleta. Sempre na dianteira a H.Stern se lança em novos desafios, apostando em novas tecnologias e novas atitudes de consumo, enquanto a Amsterdam Sauer observa, e espera pelo momento certo perdendo o "time" dos acontecimentos. Enquanto uma trabalha para se posicionar junto as maiores joalherias ${ }^{90}$ do mundo como, por exemplo, a Bulgari, Cartier, Chaumet, Tiffany \& Co., Van Cleef \& Arpels, a outra se satisfaz em ser reconhecida por suas pedras preciosas e diamantes com qualidade.

As empresas, independentemente do tempo de atuação no mercado, precisam estar preparadas para enfrentar mudanças provocadas por crises financeiras e econômicas que venham abater sobre o estado e interferir nos custos de suas mercadorias e nos hábitos de consumo dos seus clientes. Ter o melhor produto ajuda, mas nem sempre é sinônimo de sucesso. O consumidor, principalmente os de produtos de luxo, como o caso das joalherias citadas, buscam por novas experiências de consumo e que proporcionem momentos inesquecíveis. Estar atualizado quando a essas novas tendências de consumo é tarefa fundamental para aqueles que desejam se manter no mercado.

\section{As associações de classe, institutos e feiras de negócios do setor}

Em um universo competitivo, onde a concorrência anda lado a lado das empresas no mercado, as joalherias, designers e toda a cadeia produtiva que engloba o campo joalheiro buscam, através de suas entidades de classes e feiras de negócios, um espaço de atualização, apoio e divulgação de seus trabalhos. Para representar as entidades de classes temos a AJORIO Associação dos Joalheiros e Relojoeiros do Estado do Rio e o IBGM - Instituto Brasileiro de Gemas e Metais Preciosos. Quanto aos eventos de negócios criados para fomentar o crescimento econômico do campo, destacaremos a FENIJER - Feira Nacional da Indústria de Joias, Relógios e Afins, por ser considerada a mais tradicional feira de negócios realizada junto ao cenário oferecido para o setor no Brasil.

\footnotetext{
${ }^{90}$ Ver p.15 (sic).
} 
Fundada em 1965, a AJORIO ${ }^{91}$ - Associação dos Joalheiros e Relojoeiros do Estado do Rio "representa os interesses de toda a cadeia produtiva do setor, dando suporte institucional e político" ${ }^{\prime 2}$. É uma das cinco entidades que compõe o Sistema AJORIO ${ }^{93}$, que juntas, buscam atuar no mercado promovendo o fortalecimento do setor de gemas, joias, relógios e afins. Através do apoio político e institucional a projetos que atendam aos interesses de seus associados $^{94}$ e auxiliando na resolução de problemas do cotidiano, a associação declara que trabalha para enfrentar as barreiras que impedem o pleno desenvolvimento do setor como: os elevados tributos taxados pela legislação vigente em nosso país; a importação irregular de produtos que geram uma concorrência desonesta no mercado interno; e a informalidade presente em diversos pontos da cadeia produtiva que constitui o campo joalheiro do Rio de Janeiro.

Projetos como o Guia É do Rio! ${ }^{95}$, que apresenta uma seleção de criadores de joias e bijuterias do Rio de Janeiro, realizado pela própria associação, e o Guia Joia Carioca ${ }^{96}$ que reúne contatos de fornecedores de produtos e prestadores de serviços para o setor de joias e bijuterias, ambos já mencionados no capítulo anterior e desenvolvidos pela AJORIO em parceria com o SEBRAE-Rio, são veículos de divulgação e inserção dos associados no mercado, com a inclusão de novos designers de joias e empreendedores ou a promoção das empresas já atuantes, visando assim a oferta de novas oportunidades. Palestras de tendências, workshops, seminários, cursos de atualização e treinamentos de capacitação são regularmente oferecidos pela entidade, que possui em seu quadro aproximadamente 250 associados, representando cerca de 120 unidades produtivas e que fazem do Rio de Janeiro o terceiro maior estado produtor de joias do Brasil.

\footnotetext{
${ }^{91}$ A sede está localizada na Avenida Graça Aranha, 19 / grupo 404 - Centro. Rio de Janeiro.

${ }^{92}$ Sistema AJORIO. Disponível em: < http://www.sistemaajorio.com.br/site/index. php/institucionalmainmenu-63/sistema-ajorio/21-institucional/-institucional/572-sistemaajorio $>$. Acesso em: 15 de outubro de 2015.

${ }^{93}$ As cinco entidades que compõe o Sistema AJORIO são: AJORIO - Associação dos Joalheiros e Relojoeiros do Estado do Rio; SINCAJOR - Sindicato do Comércio Atacadista de Joias e Relógios do Município do Rio de Janeiro; SNCAPP - Sindicato Nacional do Comércio Atacadista de Pedras Preciosas; SINCOJOIAS - Sindicato do Comércio Varejista de Joias do Município do Rio de Janeiro e SINDIJOIAS - Sindicato das Indústrias da Joalheria e Lapidação de Pedras Preciosas do Estado do Rio de Janeiro.

${ }_{94}$ Seu grupo de associados é composto por: pequenas e médias empresas e micros empreendedores individuais, no qual se incluem os designers autônomos.

${ }_{95}$ Guia É do Rio! Disponível em: < http://issuu.com/92872/docs/522_edorio_guia___11-issuu >. Acesso em: 15 de outubro de 2015.

${ }_{96}^{96}$ Guia Joia Carioca. Disponível em: < http://www.sistemaajorio.com.br/site/index.php/entidades2/notas-mainmenu-27/300-anuncie-no-guia-joia-carioca >. Acesso em: 15 de outubro de 2015.
} 
Mudando do patamar estadual para nacional, temos o IBGM $^{97}$ - Instituto Brasileiro de Gemas e Metais Preciosos, fundado em 1977, é a entidade que representa toda a cadeia produtiva nacional, envolvendo os setores de gemas, joias, bijuterias e relógios. Localizada em Brasília, com escritório em São Paulo, conta com o apoio estadual de 18 entidades de classe ligadas à indústria de bens e insumos e o suporte de 45 empresas atuantes do campo joalheiro.

Com o objetivo de manter em constante movimento as engrenagens no campo joalheiro e procurando fornecer as ferramentas necessárias para aumentar o grau de qualidade dos produtos e serviços oferecidos, informando sobre todos os avanços e conquistas do setor, o IBGM promove ações que vão desde a organização de eventos e feiras de negócios, como a FENINFER e a TECNOGOLD ${ }^{98}$ ao desenvolvimento de produtos como: Manual de Exportação, um guia didático que reúne informações sobre os processos e procedimentos para a exportação de gemas, metais, bijuterias, folheados e afins; Preview de Design, material elaborado com uma fonte de inspiração, baseado em pesquisas de tendências e que busca a divulgação dos produtos nacionais; minicursos gratuitos e online, oferecidos em parceria com o SEBRAE, e destinados aos micro e pequenos empresários; PEIEX - Projeto de Extensão Industrial Exportadora (Apex Brasil), que busca capacitar as empresas através de consultorias nas áreas financeiras, vendas, marketing, entre outras, a operar no mercado internacional; e projetos complementares como os estudo de imagem e de mercado, para o qual uma determinada empresa pretende exportar; participação em feiras internacionais; assistência para o desenvolvimento de campanhas publicitarias e serviço de assessoria de imprensa durantes os eventos, entre outros projetos.

A FENINJER ${ }^{99}$ pelo IBGM é "o maior e mais importante evento do setor joalheiro na América Latina" e recentemente, em fevereiro de 2017, acaba de apresentar a sua $64^{\text {a }}$ edição.

Durante os meses de fevereiro e agosto, fabricantes do campo joalheiro vindos das diversas partes do país, se reúnem em São Paulo para lançarem em primeira mão suas coleções e novidades que serão tendências paras as próximas temporadas. Essa história teve início no final da década de 1970,

\footnotetext{
97 IBGM. Disponível em < http://www.ibgm.com.br/ >. Acesso em: 18 de outubro de 2015.

98 TECNOGOLD - Feira de Tecnologia, Gemas e Design. Disponível em: <www.tecnogold.com.br >. Acesso em: 10 de outubro de 2015.

${ }_{99}$ Feira Nacional da Indústria de Joias, Relógios e Afins (sic).
} 
quando um grupo de empresários joalheiros brasileiros, acostumados a frequentar as feiras de joias no exterior, se reuniu com o propósito de organizar um evento no Brasil, para alavancar as próprias vendas. Nesta época, o Rio de Janeiro era o centro de maior desenvolvimento da indústria joalheira brasileira e a cidade abrigava um polo diamantário, composto pelas empresas Antuérpia ${ }^{100} \mathrm{e}$ De Beers ${ }^{101}$ e também possuía um dos maiores parques industriais formados pelas empresas Beta e Divinal. Em 1979, com o apoio da De Beers, um grupo de empresários $^{102}$ realizou uma turnê pela região nordeste do país, visitando os capitais de Fortaleza, Recife e Salvador com o objetivo de comercializar suas produções. Após alguns eventos em terra firme, três anos depois o grupo investiu em uma ousada e inovadora estratégica para a época e embarcou a feira em um navio e os clientes que foram selecionados se sentiam honrados em participar do evento, que tinha a duração de cinco dias em alto mar.

Tempos de mercado aquecido, onde era grande a procura por peças em ouro e as vendas se faziam extraordinárias, segundo declarou o Sr. José Pascoal Constantini ${ }^{103}$, que lembra com bastante saudosismo de uma época onde "tudo era novidade" e a produção de um semestre era toda comercializada durante o evento. Almejando alcançar o mesmo sucesso dos primeiros idealizadores, outro grupo ${ }^{104}$ concorrente se formou e passou a dividir o mercado oferecendo eventos paralelos, que aconteciam em datas próximas, dividindo o público e enfraquecendo o projeto.

Com o tempo, os grupos perceberam que estavam trabalhando por um mesmo objetivo, a divulgação e comercializações de seus próprios produtos e então resolveram somar forças para organizar e que mais tarde se tornaria o maior evento de joia realizado no Brasil. Em setembro de 1985, se une ao novo grupo mais uma empresa, a Brüner, e reunindo cerca de 40 expositores, a Feira Brasileira de Joias era inaugurado no Hotel Hilton ${ }^{105}$, em São Paulo. A

\footnotetext{
100 Lapidação de Diamantes Antuérpia LTDA - dados atuais da empresa fundada em 1966. Disponível em: < http://www.cnpjbrasil.com/e/cnpj/lapidacao-de-diamantes-antuerpia-Itdame/60559341000123 >. Acesso em: 08 de outubro de 2015.

${ }^{101}$ De Beers - "mineradora sul-africana, composta por um conglomerado de empresas envolvidas na mineração e comércio de diamantes, domina boa parte do mercado mundial de extração de diamante bruto". Disponível em: < http://mundodasmarcas.blogspot.com.br/2006/08/de-beersdiamond-is-forever.html >. Acesso em: 08 de outubro de 2015.

${ }_{102}$ O grupo era composto pelas empresas: Beta, Constantini, Denoir, Duque AM, Duque SP, MFS, Metalforte, Metalnobre, Séculos e Stern Joias. Foi batizado como "Clube dos 11" apesar de só possuir dez empresas, pois houve uma desistência na véspera do primeiro evento.

103 Joalheiro e dono da empresa Constantini em declaração publicada no o catálogo oficial da $50^{2}$ FENINJER, p.64, em fevereiro de 2010.

${ }^{104}$ Composto pelas empresas: Mirandouro, Mundial, Guindani e Divinal.

${ }^{105}$ Avenida Ipiranga - SP.
} 
comodidade e a liberdade de escolha, seguindo os exemplos do que já ocorriam nas feiras internacionais, foi o grande diferencial oferecido pela feira para o campo joalheiro naquele momento. A variedade de produtos comercializados em um mesmo local atraiu muitos visitantes e fez da primeira edição, uma alavanca promissora para os futuros eventos.

O evento realizado por joalheiros com o intuito de atrair a clientela e despertar o desejo nos admiradores e consumidores de seus produtos, se transformou em um evento "profissionalizado", exclusivo para comerciantes de joias e relógios. O público convidado passou a ser selecionado, ou seja, durante o evento o joalheiro fabricante passou a oferecer suas peças diretamente para empresas que na grande maioria dos casos, não possuíam produção própria e estavam interessadas na revenda das mercadorias, montando suas coleções com os lançamentos realizados durante a feira.

Na década de 1990, o governo do então presidente Fernando Collor de Melo, visando à formalização do setor, aumentou da fiscalização das operações realizadas pelas empresas do campo. Neste momento, a gestão da FENINJER ainda estava sobre o comendo de um grupo de joalheiros, que contava com o apoio de uma empresa especializada em eventos e de uma montadora para acontecer. O IBGM, então, apresenta uma proposta, que aceita pelo grupo, passando a organizar a feira e se comprometendo em oferecer melhores condições para a sua realização.

A 34aㅡ edição da FENINJER, realizada em janeiro de 2002, reunir mais de 150 expositores passando a receber compradores vindos de várias partes do mundo, e os expositores nacionais passaram a investir no layout de suas vitrines e na decoração de seus stands tornando o evento mais requintado, ao nível dos internacionais. Em meados de 2012, 2013 a economia mundial passou por uma grande crise que automaticamente afetou o nosso país. Com as elevadas taxas de importação, a cotação do dólar nas alturas fez com que o valor do metal também subisse, inviabilizando assim muitas transações no campo joalheiro. $A$ feira também sentiu com a redução significativa do número de seus expositores, financiadores do evento, que preferiram apostar em outros meios mais econômicos de manter contato com os clientes/revendedores de suas mercadorias. Atualmente o evento busca se estabilizar e investe no seu processo de crescimento rumo ao que já foi um dia. A sua trajetória é reflexo do que aconteceu com o setor joalheiro, que desde os seus momentos de glória às 
dificuldades enfrentadas com a crise financeira e econômica que instabilizou o país, busca por alternativas para se manter vivo no mercado com a expectativa de um futuro promissor.

Atualmente a $64^{\text {a }}$ FENINJER foi realizada no WTC Events Center ${ }^{106}$ e sua visitação restrita às empresas expositoras, seus funcionários e clientes convidados, e aos profissionais atuantes no comércio de joias e relógios, previamente cadastrados no evento ou mediante a apresentação do convite oficial do evento. Quanto à visitação para os designers, vários obstáculos impedem seu acesso ao recinto. Um deles diz respeito à cópia de joias, prática na qual os responsáveis pela organização do evento atribuem a eles, mesmo não declarando diretamente. Enfim, pode-se afirmar que esta feira seria o cenário ideal para promover o encontro do designer e as empresas fabricantes de joias e assim, incentivar a contratação desses profissionais qualificados a desenvolver novos produtos, criar joias diferenciadas que atendam a necessidade real do público consumidor de cada segmento - de luxo, gemas coloridas, entre outros - que são explorados pelo evento. Infelizmente não é isso que acontece e assim, uma dúvida prevalece... Como podemos atribuir ao designer a "culpa" pelas cópias que invadiram as vitrines da FENINJER, se ele mesmo não tem acesso ao evento? Outro dado relevante, e que merece ser mencionado, se refere às feiras internacionais do setor, como por exemplo, BASEL WORLD ${ }^{107}$ na Suíça e VICENZA ORO ${ }^{108}$ na Itália, onde a visitação é aberta mediante pagamento de ingresso e sem restrição de público. Essas feiras são consideradas as maiores lançadoras de tendências, tanto no quesito design quanto em novas tecnologias de produção, para o mercado de joias mundial.

As feiras de negócios do setor joalheiro acontecem ao longo do ano e em diferentes estados do Brasil, movimentam a economia e ajudam a divulgam o trabalho realizado pelas empresas fabricantes de joias, bijuterias, folheados e insumos, e pelos designers empreendedores, atuantes no mercado, e que também comercializam suas criações para revendedores. A seguir, a tabela apresentada reúne informações como datas e localização dos principais eventos nacionais.

\footnotetext{
${ }_{106}$ Av. Nações Unidas, 12.551 / Brooklin Novo - São Paulo/SP.

107 Próximo evento: 23 a 30 de março de 2017. Disponível em: < http://www.baselworld.com/enUS.aspx >. Acesso em: 03 de março de 2017.

108 Último evento: 19 a 24 de janeiro de 2017. Disponível em: < http://january.vicenzaoro.com/en >. Acesso em: 03 de março de 2017.
} 


\begin{tabular}{|c|c|c|}
\hline Nome do Evento & Cidade & Data / Ano 2017 \\
\hline AJORESP Brasil Show ${ }^{109}$ & Campinas/SP & 20 a $22 / 03$ e 18 a 20/09 \\
\hline AJORSUL BUSINESS ${ }^{110}$ & Bento Gonçalves/RS & 23 a $25 / 03$ \\
\hline $\begin{array}{c}\text { AJORSUL FAIR } \\
\text { MERCOÓPTICA 2017 }\end{array}$ & Gramado/RS & 28 a 30/09 \\
\hline ALJOIAS $^{112}$ & Limeira/SP & 21 a $23 / 03$ e 29 a $31 / 08$ \\
\hline ATENDIMENTO VIP - BH ${ }^{113}$ & Belo Horizonte/MG & $\begin{array}{c}18 \text { e } 19 / 02 \text { e } 2^{\circ} \text { semestre } \\
\text { (data a confirmar) }\end{array}$ \\
\hline BIJOIAS $^{114}$ & São Paulo/SP & $\begin{array}{l}15 \text { a } 16 / 02 ; 26 \text { a } 27 / 04 \\
16 \text { a } 17 / 08 \text { e } 07 \text { a } 08 / 11\end{array}$ \\
\hline EXPOSOL $2017^{115}$ & Soledade/RS & $28 / 04$ a $01 / 05$ \\
\hline FA São Paulo ${ }^{116}$ & São Paulo/SP & $\begin{array}{c}18 \text { a } 19 / 04 ; 25 \text { a } 26 / 07 \\
10 \text { a } 11 / 10 \text { e } 30 / 11 \text { a } 01 / 12\end{array}$ \\
\hline FECRIS $^{117}$ & Cristalina/GO & $\begin{array}{c}2^{\circ} \text { semestre } \\
\text { (data a confirmar) }\end{array}$ \\
\hline FENINJER $^{118}$ & São Paulo/SP & 15 a $18 / 02$ e 07 a $10 / 08$ \\
\hline FIBA $^{119}$ & Rio de Janeiro/RJ & 29 a $30 / 03$ \\
\hline FIPP $2017^{120}$ & Teófilo Otoni/MG & 16 a $20 / 08$ \\
\hline
\end{tabular}

109 Feira de Joias e Folheados. Organizada pela AJORESP - Associação dos Joalheiros e Relojoeiros do Noroeste Paulista. Disponível em: < http://www.ajoresp.com.br >. Acesso em: 10 de janeiro de 2017.

110 AJORSUL - Associação do Comércio de Joias, Relógios e Óptica do Rio Grande do Sul. Feira de Joias de Ouro, Prata, Folheados, Acessórios, Pedrarias, Relógios, Óculos e Afins. Disponível em: < http://www.ajorsulbusiness.com.br>. Acesso em: 10 de janeiro de 2017.

Feira de Joias, Relógios, Óptica e Afins. Disponível em: <http://www.ajorsulfairmercooptica.com.br >. Acesso em: 10 de janeiro de 2017.

${ }^{112}$ Feira Internacional de Joias Folheadas, Brutos, Máquinas, Insumos e Serviços. Disponível em: $<$ http://www.aljoias.com.br >. Acesso em: 10 de janeiro de 2017.

${ }_{113}$ Feira Nacional de Folheados, Bijuterias, Joias em Prata, Aço Inox e Acessórios de Moda. Informações pelo e-mail: contatoatbh@hotmail.com.

114 Feira de Acessórios, Bijuterias, Joias de Prata, de Aço e Folheados. Disponível em:< http://www.bijoias.com.br/>. Acesso em: 10 de janeiro de 2017.

${ }^{115}$ Feira Internacional de Pedras Preciosas. Disponível em: < http://www.exposol.com.br/web>. Acesso em: 10 de janeiro de 2017.

116 Feira de Joias Folheadas, Prata, Aço e Acessórios de Moda. Disponível em: < http://www.fasaopaulo.com.br >. Acesso em: 10 de janeiro de 2017.

117 Feira de Joias, Artesanato Mineral e Pedras Preciosas de Cristalina. Disponível em: < feirafecris@hotmail.com >. Acesso em: 10 de janeiro de 2017.

${ }^{118}$ Feira Nacional da Indústria de Joias, Relógios e Afins (sic).

${ }^{119}$ Feira Internacional de Bijuterias e Acessórios. Disponível em: < http://fiba.com.br/>. Acesso em: 10 de janeiro de 2017.

120 Feira Internacional de Pedras Preciosas - Teófilo Otoni. Disponível em: < http://www.teofilootoni.mg.gov.br/site/turista/feira-internacional-de-pedras-preciosas/ >. Acesso em: 10 de janeiro de 2017. 


\begin{tabular}{|c|c|c|}
\hline FRANCAL 2017 & São Paulo/SP & 02 a 05/07 \\
\hline MINAS TREND $^{122}$ & Belo Horizonte/MG & $\begin{array}{c}04 \text { a 07/04 } \\
\text { semestre (data a } \\
\text { confirmar) }\end{array}$ \\
\hline MOSTRA GUAPORÉ 2017 & Guaporé/RS & 04 a 06/08 e 11 a 13/08 \\
\hline SOLEDADE É JOIA & $\begin{array}{c}2^{\text {o }} \text { semestre (data a } \\
\text { confirmar) }\end{array}$ \\
\hline TECNOGOLD & Soledade/RS & $\begin{array}{c}2^{\circ 25} \text { semestre (data a } \\
\text { confirmar) }\end{array}$ \\
\hline
\end{tabular}

Tabela 01 - Relação dos eventos comerciais que atendem ao campo joalheiro no Brasil.

Conforme os dados apresentados na tabela ${ }^{126}$, podemos verificar que ao longo do ano de 2017, somente no Brasil, a previsão inicial é de 28 eventos comerciais - feiras de joias, folheados, bijuterias, acessórios, relógios, gemas, maquinários e afins direcionadas ao campo joalheiro, nos quais, um pouco mais da metade, 57,15\% estão concentrados em São Paulo, sendo 12 feiras na capital, 2 em Campinas e 2 em Limeira; 17,85\% no Rio Grande do Sul, com 2 feiras em Soledade, e 1 em Gramado, Guaporé e Bento Gonçalves; $17,85 \%$ em Minas Gerais, com 4 feiras em Belo Horizonte e 1 em Teófilo Otoni; 3,57\% em Goiás, com uma feira em Cristalina e o Rio de Janeiro, também com $3,57 \%$, e uma feira realizada na capital. Ou seja, para o estado que é reconhecido como um dos principais no setor joalheiro nacional, o Rio de Janeiro possui um número insignificante para a sua posição, obrigando seus produtores e designers autônomos a se deslocarem e investirem em eventos realizados em outros estados, como São Paulo, por exemplo.

121 Feira de Calçados, Acessórios de Moda, Bijuterias, Joias Folheadas, Máquinas, Couro e Componentes. Disponível em: <http://www.feirafrancal.com.br/2016/>. Acesso em: 10 de janeiro de 2017.

${ }_{122}$ Salão de negócios que reúne expositores e lojistas dos segmentos de vestuário, calçados, bolsas, joias e bijuterias. Disponível em: < http://www.minastrend.com.br>. Acesso em: 10 de janeiro de 2017.

${ }_{123}$ Feira de Joias e Lingeries. Disponível em: < http://www.mostraguapore.com.br >. Acesso em: 10 de janeiro de 2017.

${ }^{124}$ Feira Internacional de Joias. Disponível em: < http://www.soledadejoia.com.br/>. Acesso em: 10 de janeiro de 2017.

${ }_{125}$ Feira Internacional de Máquinas para o Setor de Joias, Gemas, Bijuterias e Metais Preciosos (sic).

${ }^{126}$ Calendário 2017 das feiras no Brasil. Disponibilizado pelo portal JOIA BR. Disponível em: < http://www.joiabr.com.br/feiras/feirasbr.html >. Acesso em: 10 de setembro de 2015. 


\section{Eventos de Moda e Design e veículos de comunicação}

Outras feiras como a COUROMODA ${ }^{127}$, direcionada para o segmento de calçados e artefatos em couro e acessórios de moda; CRAFT DESIGN ${ }^{128}$ e PARALELA GIFT ${ }^{129}$ voltadas para o campo do design de produtos e suas diversas aplicações na moda, acessórios e decoração; MEGA ARTESANAL ${ }^{130}$ que atende ao setor de arte e artesanato, também representam oportunidades para o setor joalheiro crescer abrindo caminhos em outros mercados.

O evento Fashion Rio, criado na década de 1990, figurou entre os acontecimentos de moda mais importantes do Brasil, apostando em novos criadores, reunindo ícones de renome no mercado e divulgando a marca "Rio" para o mundo fashion. Em 2001 o Sistema FIRJAN assumiu a organização do evento que mais tarde, em 2009, passou para a responsabilidade de Paulo Borges. Criador e também diretor da São Paulo Fashion Week - SPFW ${ }^{131}$, Borges $^{132}$ planejava com o tempo transformar o Fashion Rio em um evento focado na moda-praia e assim diminuir a concorrência existente entre os dois eventos, que sob a sua direção, aconteciam em datas muito próximas dividindo o público e gerando um investimento oneroso em tempos de crise para as marcas participantes. Desde a edição de Inverno de 2015, quando seus organizadores anunciaram o cancelamento do evento ${ }^{133}$, o Fashion Rio está suspenso para reformulação de suas estratégias. Com isso, a FIRJAN, detentora do marca, se mostrando preocupada com o futuro da indústria de moda no estado, criou o Fórum da Moda, reunindo empresários e estilistas cariocas a pensarem sobre o futuro do setor no Rio de Janeiro.

\footnotetext{
${ }^{127}$ Feira Internacional de Calçados e Artefatos em Couro e Acessórios de Moda. Disponível em: < http://www.couromoda.com >. Acesso em: 10 de setembro de 2015.

${ }^{128}$ Feira de Negócios e Tendências na Área de Decoração, Design e Arte. Disponível em: < http://www.craftdesign.com.br >. Acesso em: 10 de setembro de 2015.

${ }_{129}$ Design Autoral, Decoração e Artesanato Contemporâneo - Aromas e cosméticos, artes plásticas, artesanato, cerâmica, joalheria, iluminação, mobiliário, papelaria, utilitário, entre outros. Disponível em: < http://www.paralelagift.com.br >. Acesso em: 10 de setembro de 2015.

${ }^{130}$ Feira de Produtos Artesanais. Disponível em: < http://wrsaopaulo.com.br/index.php/2012-08-1714-57-49/mega-artesanal >. Acesso em: 10 de setembro de 2015.

131 Informações sobre a Semana de Moda de São Paulo - Fashion For Ward SPFW. Disponível em: < http://ffw.uol.com.br/spfw/n42/>. Acesso em: 10 de janeiro de 2017.

132 Paulo Borges, em entrevista a jornalista Lilian Pacce, fala sobre o Fashion Rio, 2009. Disponível em: < http://www.lilianpacce.com.br/moda/paulo-borges-fashion-rio/>. Acesso em: 10 de janeiro de 2017.

${ }_{133}$ Pronunciamento sobre o cancelamento da Fashion Rio, edição de Inverno 2015. Disponível em: < http://ffw.uol.com.br/fashion-rio/verao-2015-rtw/>. Acesso em: 10 de janeiro de 2017.
} 
Depois veio o Rio Moda Rio, evento que surgiu em 2015, e não resistiu nem até a sua segunda edição, com data adiada para o início de $2017^{134}$. Seguindo os acontecimentos, temos a Veste $\operatorname{Rio}^{135}$, uma feira de negócios criada por duas das mais relevantes publicações de moda do país - Caderno ELA, do GLOBO, e revista Vogue. Realizado na Marina da Glória, entre os dias 19 a 22 de outubro de $2016^{136}$, o evento reuniu fabricantes e lojistas para o lançamento de suas coleções e contou também com um espaço outlet ${ }^{137}$, onde marcas famosas ofereciam descontos de até $70 \%$.

Além dos desfiles e feiras de negócios promovidas pelo mercado da moda podemos listar as revistas de moda; colunas e cadernos de jornais de grande circulação; produções de moda para editoriais; telenovelas brasileiras; formadores de opinião; sites, blogs e demais veículos digitais, como alguns dos meios de comunicação usados para divulgação de seus produtos pelo do campo joalheiro. Como a intenção de "ser notícia" e ter o acesso facilitado a esses veículos, o papel da assessoria de imprensa, para os que podem arcar com mais uma despesa, é fundamental no processo e representar uma "vantagem" dentro de um universo competitivo como encontramos na moda ou na joalheria. Sendo assim, podemos verificar que as empresas e designers que contratam esse tipo de serviço apresentam uma frequência maior de divulgação junto a essas mídias, perante aos concorrentes que não o fazem.

Dentro do conjunto dos veículos de comunicação impressos e especializados, não existe uma publicação dedicada e exclusiva ao campo joalheiro no Brasil. Já tivemos edições especiais da revista Vogue Joias e que desde o final da década de 2000 não são mais produzidas, período em que a Editora Globo, responsável pela publicação, passou a atender empresas que buscam fazer seus catálogos em forma de revistas como no caso da H.Stern, seguida pela Amsterdam Sauer. As revistas de moda, como por exemplo, a própria Vogue ou Marie Claire e Glamour da Editora Globo, ELLE, Claudia, Cosmopolitan e Estilo de Vida da Editora Abril, mesmo apresentando matérias sobre o assunto joia, relacionam as peças em produções de moda como se uma joia dependesse somente do fator

\footnotetext{
134 Baixa na Temporada: Rio Moda Rio adiado. Lilian Pacce, 2016. Disponível em: < http://www.lilianpacce.com.br/desfiles/baixa-na-temporada-rio-moda-rio-adiado/>. Acesso em: 10 de janeiro de 2017.

${ }_{135}$ Veste Rio. Disponível em: < http://vesterio.rio/>. Acesso em: 10 de janeiro de 2017.

${ }^{136}$ Veste Rio faz Marina da Glória o porto da Moda. O GLOBO. Luiza Barros. 2016. Disponível em: < http://oglobo.globo.com/rio/veste-rio-faz-da-marina-da-gloria-porto-da-moda-19275847>. Acesso em: 10 de janeiro de 2017.

${ }^{137}$ Outlet - termo em inglês utilizado para definir o espaço onde fabricantes ou lojistas oferecem seus produtos, a preço de fábrica, diretamente para o consumidor final.
} 
"moda" para ser consumida. O Caderno Ela e a Revista de Domingo, ambos do jornal O Globo também seguem o mesmo propósito, pois falam de moda, estilo de vida e outras amenidades.

As telenovelas, principalmente as da Rede Globo, são tidas como meios eficazes de divulgação para o campo. As figurinistas recorrem cada vez mais ao trabalho de designers autônomos para compor o look dos personagens da trama. Uma peça que se identifique com a história de vida de uma protagonista, por exemplo, e que vire objeto de desejo dos telespectadores, poderá representar uma oportunidade de visibilidade, a nível nacional, de um designer ainda desconhecido no mercado. Fora das telas, ter um artista usado uma de suas peças significa propaganda gratuita e vinculada à sua imagem. Essa estratégia pode ser observada quando uma determinada celebridade é presenteada por uma joalheira, com a intenção de que use as peças em um evento especial ou mesmo no seu dia a dia gerando o que conhecemos por mídia espontânea.

No meio digital destacamos o Joia $\mathrm{BR}^{138}$, um portal de informações dedicado às notícias do campo joalheiro, com a divulgação dos contatos de empresas, designers e entidades de classe; programação de feiras e eventos nacionais e internacionais; classificado com ofertas de cursos e informações de concursos; cotação do dólar; manual de gemas; entrevistas com especialista em diversos assuntos relacionados com o campo; artigos sobre assuntos diversos que envolvem desde a história da joalheria, gemologia, registros autorais de joias às dicas de marketing e gerenciamento do negócio, entre outros. Há 17 anos "no ar" o portal acaba de anunciar que dará "uma pausa", suspendendo sua operação ${ }^{139}$ no final do mês março de 2017. E diante desta notícia pensamos: será que o setor não se interessa por informações do próprio campo em que atua? Será que é pela falta de patrocinadores para que ele continue a operar? Ou será que este veículo de divulgação e legitimação do campo não é mais reconhecido por seus membros?

\footnotetext{
138 Disponível em: < http://www.joiabr.com.br/ >. Acesso em: 10 de janeiro de 2017.

139 Disponível em: < https://www.facebook.com/joiabr/?fref=ts >. Acesso em: 01 de março de 2017.
} 


\section{3}

\section{O ensino do design de joias no Rio de Janeiro}

Atualmente o ensino do design de joias no Rio de Janeiro, levando em consideração a carga horária das aulas e o tipo de certificação conferida a seus alunos, pode ser dividido em quatro categorias distintas, a saber: i) o ensino de nível superior onde é concedido aos concluintes o grau de bacharel, e especialista para os pós-graduados lato sensu; ii) o ensino profissionalizante com a certificação de nível técnico; iii) o ensino através dos cursos livres, oferecidos em ateliês, com os certificados de participação, que não são reconhecidos pelas entidades oficiais; vi) o ensino a distância que vai depender do tipo do curso oferecido, sendo ele na categoria livre, extensão ou mesmo pósgraduação.

Segmentado, o ensino não está focado apenas no produto joia, mas nas etapas de sua concepção, que se estendem desde as técnicas de criação, representação artística, desenho técnico, desenvolvimento de coleções; passando pelas técnicas tradicionais de produção, lapidação e classificação de gemas, cravação e gravação em metal; finalizando com os meios mais tecnológicos de fabricação, com a modelagem virtual e impressão 3D. Empreendedorismo, organização e informatização de estoque, precificação, técnicas de venda, vitrines, formalização e emissão de nota fiscal, finanças, importação e exportação, são exemplos de algumas áreas importantes, que também são procuradas pelos integrantes do campo com o objetivo de aprimorarem seus conhecimentos.

\section{O ensino oferecido por instituição de nível superior}

A formação do designer de joias, por instituições de ensino superior no Rio de Janeiro, é uma prática considerada recente no Brasil, se comparada à tradição do ensino e a oferta de cursos nos países europeus. Este fato pode ser comprovado a partir da analise do currículo acadêmico apresentado por professores estrangeiros ${ }^{140}$, que residem e trabalham no Rio de Janeiro, onde eventualmente possuem seus ateliês.

\footnotetext{
${ }^{140}$ Rudolf Ruthner é graduado pela Escola de Ourivesaria em Viena - 1955 a 1959, na Áustria; estudou técnicas de gemologia, esmaltação a fogo, cinzelagem e pintura - 1960 a 1964; obteve o título de Mestre Ourives e Mestre Prateiro - 1965 e 1966, na mesma instituição; e em Munique, na Alemanha, se especializou em peças desenvolvidas com platina - 1966 a 1967, ou seja, há 62 anos, no mínimo, temos a comprovação da existência dos cursos de ourivesaria sendo oferecidos
} 
No Brasil, as instituições de nível superior com programas direcionados ao campo joalheiro são: Pontifícia Universidade Católica do Rio de Janeiro - PUCRio e Universidade Veiga de Almeida - UVA. Com aproximadamente uma década de existência, juntas elas já formaram cerca de 350 profissionais, em nível de pós-graduação e graduação respectivamente. Por decorrência da baixa demanda os cursos estão suspensos a espera de candidatos interessados para a formação de novas turmas. Para complementar, além desses cursos superiores, podemos encontrar como uma alternativa e em atividade, as instituições que oferecem o Curso Superior de Desenho Industrial com habilitação em Projeto de Produto, em que o aluno poderá eleger a joia como seu produto principal e assim, desenvolver projetos de coleções durante o seu período de graduação.

No Rio de Janeiro, encontramos o Curso de Desenho Industrial / Projeto de produto oferecido por algumas instituições de ensino ${ }^{141}$, sendo nas universidades federais, com a Universidade Federal do Rio de Janeiro - UFRJ e Universidade Federal Fluminense - UFF; estaduais com a Universidade do Estado do Rio de Janeiro - UERJ; e particulares com a PUC-Rio - Pontifícia Universidade Católica do Rio de Janeiro e pela UNESA - Universidade Estácio de Sá.

\section{Pontifícia Universidade Católica do Rio de Janeiro - PUC-Rio}

A Especialização em Design de Joias ${ }^{142}$, oferecida pela Coordenação Central de Extensão - CCE, da PUC-Rio, foi a primeira pós-graduação lato sensu em Design de Joias do Rio de Janeiro e do Brasil. Em 2000 teve início a sua primeira turma e ao longo de 10 anos de funcionamento, graduou cerca de 200 especialistas, divididos em duas habilidades: i) Design de Joias, com 429 horas de carga horária, e foco principal na concepção de projetos de joias, bijuterias adornos pessoais; ii) Design de Joias e Ourivesaria, com 609 horas, sendo mais completo, indo além das etapas de criação e desenvolvimento das joias,

por instituições de ensino superior em outros países. No Brasil, lecionou a disciplina de Ourivesaria na PUC-Rio e na UVA. Currículo Lattes. Disponível em: < http://lattes.cnpq.br/3068000112877106 $\rightarrow$ Acesso em: 14 de novembro de 2015.

${ }_{141}$ Gui do Estudante. Disponível em:< http://guiadoestudante.abril.com.br/profissoes/artesdesign/design-684673.shtml >. Acesso em: 05 de novembro de 2015.

${ }_{142}$ Atualmente esta pós-graduação está sendo oferecida com a carga horária de 597h. Disponível em: < http://www.cce.puc-rio.br/sitecce/website/website.dll/folder?nCurso=design-de-joias-eourivesaria\&nlnst=cce $>$. Acesso em: 14 de novembro de 2015. 
estendendo seus conhecimentos as técnicas de ourivesaria, através de aulas práticas, ministradas em parceria com o SENAI-RJ, e nas suas oficinas.

Com a duração de um ano, o programa é apresentado em dois módulos, nos quais técnicas tradicionais de desenho à representação gráfica são ensinadas com auxilio de softwares especializados, passando pela história da joalheria, pelos estudos da antropologia do consumo, de tendências, de gemologia, de materiais e processos de produção ao desenvolvimento de projetos, finalizando com a apresentação de uma monografia, na qual o aluno deverá aplicar todo o conhecimento desenvolvido ao logo das disciplinas.

Durante o II Seminário: Atualização Tecnológica e o Setor de Joias e Bijuterias $^{143}$, que aconteceu no dia 23/11/2015, reunindo no Centro de Convenções da FIRJAN diversos profissionais e empresários envolvidas com o campo joalheiro do Rio de Janeiro, foi apresentado uma breve retrospectiva sobre o curso da PUC-Rio, que ao longo dos anos, formou de 13 turmas, resultando em 4 pesquisas de iniciações científicas, 3 dissertações de mestrado, 2 teses de doutorado; projetos desenvolvidos a partir da criação da Incubadora de Design, com 5 empresas incubadas e um curso voltado para o empreendedorismo; exposições de trabalhos de conclusão para inserção dos alunos no mercado joalheiro; e a criação do Laboratório de Observação de Joias e Afins - LOJA e do Laboratório de Pesquisa e Modelagem 3D - INOTEC.

Sem previsão de data, atualmente a especialização aguarda a formação de uma nova turma e enquanto isso, a graduação em Design, que possui habilitações em Projeto de Produto, Moda, Mídia Digital e Comunicação Visual, oferece a oportunidade de contato com o universo da joalheria através das disciplinas de projeto da habilitação Projeto de Produto, em que o aluno, com o auxílio de professores experientes no campo joalheiro, é orientado no desenvolvimento de uma coleção de joias.

\section{Universidade Veiga de Almeida - UVA}

O Curso Superior de Tecnologia em Design de Produto - Joias, da Uva, inaugurou suas atividades no primeiro semestre de 2005, e oferecido no campus Barra Marapendi, possuía uma oficina totalmente equipada com o ferramental necessário para o ensino das mais diversas técnicas de ourivesaria. O curso que

\footnotetext{
${ }^{143}$ Consulte o site da AJORIO para mais Informações sobre este seminário. Disponível em: < http://www.sistemaajorio.com.br/site/index.php/servicos/capacitacao?task=view_event\&event_id=4 6 >. Acesso em: 05 de novembro de 2015.
} 
inicialmente contou com a participação do Instituto Zuzu Angle, apoio e divulgação da AJORIO, foi patrocinado da Mineradora Anglo Gold Ashanti para equipar sua oficina, e também, pela equipe técnica da Joalheria Amsterdam Sauer, com a elaboração do projeto e da planta de instalação da capela de fundição, com exaustor de gases tóxicos, e captadores de resíduos sólidos no sistema hídrico do novo espaço.

Com duração de 2 anos e 2.000 horas de carga horária, dividido em quarto módulos: Básico; Joalheria Conceitual; Joalheria Comercial e Coleções de Joias, seu projeto pedagógico foi estruturado de modo a oferecer ao estudante uma abordagem completa das etapas que envolvem a criação, o desenvolvimento e a produção de coleção, seja ela comercial ou conceitual, passando pela história do design, da arte e da joalheria, pelas técnicas de representação artística e de concepção técnica, às técnicas de ourivesaria, básica e avançada.

Em agosto de 2011 o curso foi avaliado e reconhecido pelo $\mathrm{MEC}^{144}$ recebendo o conceito máximo, nota 5 (cinco). Coincidentemente, neste mesmo ano, por decorrência da baixa procura que já havia acontecendo, desde o final de 2009, a instituição suspendeu temporariamente a oferta do curso vindo mais tarde a encerrar suas atividades. Aos alunos interessados no campo joalheiro, ficou a opção da disciplina de Projeto de Adornos, que é oferecida dentro do curso Superior de Moda, e que em sua ementa engloba além das joias e bijuterias, as bolsas, sapatos, cintos, óculos entre outros.

Com o início previsto para 2012 e visando atender a demanda do seu egresso que buscava por um complemento em sua formação no campo do design, a UVA passou a ofertar um curso de pós-graduação em Joalheria Contemporânea ${ }^{145}$, com duração de 18 meses e 480 horas de carga horária. $O$ curso, que durante 4 anos aguardou pela formação da sua primeira turma, atualmente não é mais oferecido.

Diante aos fatos apresentados podemos verificar que a partir de 1990, época em que vivenciamos o fortalecimento da economia interna brasileira, atingindo positivamente o do setor joalheiro, estas instituições levaram cerca de 10 anos para se organizarem e começarem a oferecer seus cursos aos interessados pela

\footnotetext{
${ }_{144}^{144}$ MEC - Mistério da Educação e Cultura

145 Pós-graduação em Joalheria Contemporânea oferecida pela UVA. Disponível em:< https://www.uva.br/sala-de-imprensa/releases/uva-abre-inscricoes-para-nove-cursos-de-posgraduacao >. Acesso em: 14 de novembro de 2015.
} 
profissão ou simplesmente para aqueles que buscavam por uma titulação com uma pitada de glamour, que conforme mencionado na introdução da pesquisa, envolve o ofício da joalheria.

Durante os 10 anos subsequentes estas instituições ofereceram seus cursos até cessar a demanda existente no mercado e hoje, a quantidade de interessados não chega a um número suficiente para que se iniciem novas turmas, sem a geração de prejuízos financeiros para as instituições.

O Instituto Europeu de Design - IED ${ }^{146}$ que no Brasil inaugurou, em 2005, a sua primeira unidade sediada em São Paulo, somente em maio de 2014, abre sua filial do Rio de Janeiro, na praia da Urca, se instalando no edifício onde tempos atrás, abrigou o antigo Cassino da Urca e a histórica TV Tupi.

Classificado dentro da categoria de cursos especiais, pois não pode ser considerada uma graduação devido ao período curto de sua carga horária, IED Rio oferece para início no segundo semestre de 2017, uma turma para o curso de Design de Joias ${ }^{147}$. Com 60 horas de carga horária, o programa oferece capacitação para a criação de coleção de joias, bijuterias e relógios, e dentro de uma metodologia aplicada ao design, vai trabalhar em três segmentos: cultural, onde o aluno terá contato com a história do design de joias; tecnológico, que envolvem técnicas de produção; e projetual, que aborda o desenvolvimento de coleções, pesquisas e estudos de formas tridimensionais a construção e organização de um book com o projeto que será executado pelo aluno.

\section{O ensino profissionalizante oferecido por instituição de nível técnico}

O ensino profissionalizante para o campo joalheiro é fornecido pelo Sistema $S^{148}$, que composto por nove instituições, das quais podemos destacar o SENAI Serviço Nacional de Aprendizagem Industrial e o SENAC - Serviço Nacional de

${ }^{146}$ Desde 1966, pioneiro entre as universidades italianas de design, contribui para o ensino no Campo do Design. Reunindo características das escolas profissionalizantes com o ensino tradicional oferecido pela Academia, acreditam na formação plena de seus alunos, que vai desde a concepção a materialização das ideias e as palavras de Francesco Morelli, seu fundador - "Saber e saber fazer" - formam a base de seu projeto pedagógico.

147 Design de Joias no IED Rio. Disponível em:< http://ied.edu.br/rio/curso/cursosespeciais/designde-joias/>. Acesso em: 14 de novembro de 2015.

148 "O Sistema S conta com uma rede de escolas, laboratórios e centros tecnológicos espalhados por todo o território nacional". Fazem parte do Sistema S: SENAI - Serviço Nacional de Aprendizagem Industrial; SESC - Serviço Social do Comércio; SESI - Serviço Social da Indústria; IEL - Instituto Euvaldo Lodi; SENAC - Serviço Nacional de Aprendizagem do Comércio; SENAR Serviço Nacional de Aprendizagem Rural; SNAT - Serviço Nacional de Aprendizagem em Transportes; SESCOOP - Serviço Nacional de Aprendizagem do Cooperativismo; e SEST -

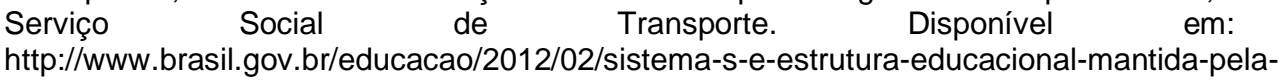
industria >. Acesso em: 30 de novembro de 2015. 
Aprendizagem Comercial, com cursos $100 \%$ práticos, em diversas modalidades que são selecionadas e oferecidas de acordo com as demandas do mercado.

Os cursos profissionalizantes podem atender como um complemento junto à formação superior ou mesmo, como primeira fonte de ensino para profissionais interessados em entrar no mercado de trabalho, ou para jovens iniciantes que são selecionados pelas empresas para participarem do Programa Jovens Aprendiz, e que durante o período de treinamento, começam a desenvolvem suas habilidades através da prática diária da profissão.

\section{SENAI - Serviço Nacional de Aprendizagem Industrial}

Fundado em 1942, o SENAI ${ }^{149}$, entidade sem fins lucrativos e que integra o sistema FIRJAN ${ }^{150}$, é considerado a maior instituição de ensino profissionalizante da América Latina, ficando também entre as cinco maiores do mundo. Com o objetivo de atender a demanda da indústria nacional, oferecendo cursos em 28 áreas diferentes, abraçando desde a formação técnica/profissionalizante, passando pelos cursos de graduação até a pós-graduação tecnológica.

Situada na Unidade Tijuca ${ }^{151}$, a Escola de Ourivesaria, em 2002, apresentou uma programação com enfoque principal nas técnicas básicas de ourivesaria, pois acreditavam ser o alicerce para o desenvolvimento dos demais processos de produção. O programa inicialmente foi dividido em três etapas: Técnicas Básicas de Ourivesaria, com carga horária de 60 horas; Técnicas de Planejamento e Confecção em Ourivesaria, com carga horária de 81 horas; Técnicas Avançadas de Planejamento e Confecção de Joias, com carga horária de 120 horas, sendo oferecidas para os interessados em geral, com formação superior ao $8^{\circ}$ ano do Ensino Fundamental.

Posteriormente o programa sofreu alteração condensando os três módulos em dois, da seguinte forma: Técnicas Básicas de Produção de Joias, com carga horária de 180 horas e Fundamentos de Joalheria, com carga horária de 100 horas. Além dos cursos técnicos de ourivesaria, em 2006, o SENAI ofereceu a qualificação "Joalheiro", com duração de 12 meses e carga horária de 764 horas.

\footnotetext{
149 SENAI - Serviço Nacional de Aprendizagem Industrial. Disponível em: < http://www.portaldaindustria.com.br/senai/institucional/2015/05/1,1776/historia.html/>. Acesso em: 10 de novembro de 2015.

150 Sistema FIRJAN - Federação das Indústrias do Estado do Rio de Janeiro. Disponível em: < http://www.firjan.com.br/o-sistema-firjan/>. Acesso em: 14 de novembro de 2015.

${ }^{151}$ Unidade Tijuca fica localizada na Rua Moraes e Silva, $n^{\circ} 53$.
} 
Cursos livres de Modelagem em Cera, Técnicas Básicas de Cravação de Gemas em Joias, Criação de Joias, entre outros, também são oferecidos pela unidade.

O SENAI participa do Programa Jovem Aprendiz ${ }^{152}$ em parceria com empresas do campo, como por exemplo, a H.Stern que além de um estágio oferece cursos de qualificação em ourivesaria, buscando estimular os estudantes provenientes de escolas públicas e com boas notas, a se profissionalizarem visando uma oportunidade futura de se encaixarem neste segmento do mercado de trabalho. O Programa, que tem duração de no máximo de dois anos, oferece uma jornada de trabalho de 6 horas e além do salário, benefícios como vale transporte e alimentação, férias e $13^{\circ}$ salário.

O SENAI organiza e estimula a participação dos jovens nas Olimpíadas do Conhecimento e no WorldSkills Competition, em que estudantes de 62 nacionalidades, e com menos de 22 anos de idade, disputam provas práticas e elaboradas com exercícios que simulam situações reais de trabalho, no qual os competidores são avaliados por sua precisão técnica, capacidade/tempo de execução das tarefas e habilidades pessoais. A Escola de Ourivesaria do Rio de Janeiro já conquistou inúmeros prêmios com seus representantes e a cada turma concluinte, podemos destacar muitos jovens dedicados e interessados em seguir na profissão, como o caso do carioca Leonardo Fonseca ${ }^{153}$, aprendiz de ourivesaria na joalheria H.Stern e medalha de ouro na WorldSkills São Paulo 2015.

Atualmente, a Escola de Ourivesaria passa por um novo processo de adequação de seus cursos para alinhar com as novas demandas do mercado. Com a mudança da escola para a Unidade Maracanã ${ }^{154}$, passou a oferecer um único curso em Modelagem 3D ${ }^{155}$, nível básico de aperfeiçoamento profissional e com carga horária de 100 horas. O aluno será capacitado a projetar modelos digitalizados de joias e bijuterias utilizando software de modelagem tridimensional específico para o campo. Através da capacitação desses

\footnotetext{
152 O Programa Jovem Aprendiz. Disponível em:< http://www.programadogoverno.org/pronatecjovem-aprendiz-2015-e-2016/>. Acesso em: 10 de novembro de 2015.

153 Os Competidores. Disponível em:< http://www.portaldaindustria.com.br/senai/canal/delegacaobrasileira/>. Acesso em: 10 de novembro de 2015.

Para saber mais sobre o vencedor, consulte o site da CNI. Disponível em:< http://www.portaldaindustria.com.br/cni/imprensa/2015/07/1,66764/leonardo-descobriu-uma-novaprofissao-e-agora-planeja-montar-a-propria-joalheria.html>. Acesso em: 10 de novembro de 2015.

${ }_{154}^{154}$ Localizada na Rua São Francisco Xavier, n 417 - Maracanã - Rio de Janeiro.

155 Conteúdo completo do curso de Modelagem 3D oferecido pelo SENAI. Disponível em:< https://www.cursosenairio.com.br/curso-modelagem-3d-basico,18,2,0,0,37146.html\#>. Acesso em: 15 de novembro de 2015.
} 
profissionais, o SENAI aposta no fortalecimento das novas tecnologias e na abertura de novas oportunidades de trabalho dentro das indústrias que buscam inovar etapas no seu processo produtivo.

\section{SENAC - Serviço Nacional de Aprendizagem Comercial}

Por intermédio do decreto-lei 8.621, o SENAC ${ }^{156}$ foi criado em 1946 com o objetivo de ser uma instituição de ensino que prioriza a educação profissionalizante direcionada ao Setor do Comércio de Bens, Serviços e Turismo. Instituição privada e de finalidade pública está sempre engajada na promoção do desenvolvimento social. Sua administração nacional fica a cargo da CNC - Confederação Nacional do Comércio de Bens, Serviços e Turismo e seu gerenciamento regional comandado pela Fecomércio - Federação do Comércio do Estado do Rio de Janeiro, do qual também, recebe auxílio através do recolhimento da contribuição sindical compulsória das empresas ligadas ao comércio e de seus empregados, que independentemente de suas condições perante as associações sindicais, filiados ou não, contribuem com um valor correspondente a remuneração de um dia de trabalho.

Em 2006, o Centro de Tecnologia em Design do SENAC-Rio, unidade Barra da Tijuca $^{157}$, ofereceu em suas instalações recém-inauguradas e modernamente equipadas, o curso em Design de Joias ${ }^{158}$, com carga horária de 400 horas, para alunos com o ensino médio completo e idade superior a 18 anos. Os interessados eram capacitados a desenvolver desde o conceito aos meios de comercialização das próprias coleções de joias, passando pela prática das técnicas de representações bidimensionais, com desenhos à mão livre e técnicos com o auxílio de instrumentos; pelos estudos da forma e da ergonomia; pelo conhecimento do desempenho dos materiais e da matéria-prima utilizada na confecção de peças em metal; por pesquisas de tendências, moda e dos demais aspectos que se relacionam com o usuário e com o mercado, além das condutas comportamentais e de relacionamento para com os clientes.

Distribuídos em três níveis diversificados de aprimoramento e com aulas 100\% práticas, atualmente os cursos de SENAC-Rio que destinados ao campo

\footnotetext{
156 SENAC - Serviço Nacional de Aprendizagem Comercial. Disponível em: < http://www.senac.br/institucional/senac.aspx />. Acesso em: 12 de novembro de 2015.

${ }_{157}$ Localizado no Casa Shopping, na Av. Ayrton Senna, 2150 Bloco E / 3ํandar - Barra da Tijuca. Disponível em: < http://www.designbrasil.org.br/design-em-pauta/extensaprogramacao-de-cursos-no-centro-de-tecnologia-em-design-do-senac-rio/ >. Acesso em: 12 de novembro de 2015.

${ }_{158}$ Design Brasil. Disponível em: <http://www.designbrasil.org.br/agenda/design-de-joias-no-senacrio/\#.Vk_ixPmrShc >. Acesso em: 20 de novembro de 2015.
} 
joalheiro ${ }^{159}$ são oferecidos na unidade Copacabana ${ }^{160}$, sendo eles: Ourivesaria, com carga horária de 140 horas; Confeccionador de Bijuterias, de capacitação com carga horária de 160 horas; de aperfeiçoamento em Design de Joias, com carga horária de 219 horas; em Técnicas Avançadas de Ourivesaria, com carga horária de 120 horas; em Desenho de joias e Bijuterias com carga horária de 112 horas; Introdução ao Rhinoceros com carga horária de 24 horas e em Rhinoceros para Joalheiros, com carga horária de 81 horas. Além dos cursos já listados, são ofertados ocasionalmente workshops, com carga horária reduzida, e que abordam temas específicos dentro do universo joalheiro com, por exemplo, o trabalho manual com o titânio, no qual o aluno confecciona um pendente e aprende as técnicas de coloração desse metal.

O SENAC, em prol do crescimento e desenvolvimento do campo joalheiro no estado do Rio de Janeiro, também participa do Programa Jovem Aprendiz, destinado a capacitação de jovens, com idade entre 14 e 22 anos, no mercado de trabalho. Segundo o projeto pedagógico do curso Aprendizagem Profissional Comercial em Serviços de Ourivesaria ${ }^{161}$, que possui carga horária de 1.200 horas, o ensino é dividido em dois módulos: Básico, com duração de 80 horas e Ourivesaria com 520 horas, que se completam com as 600 horas oferecidas de prática profissional em situação real de trabalho.

Os cursos profissionalizantes oferecidos pelo SENAI e pelo SENAC, também sentem com a baixa do quantitativo de alunos e da escassez da demanda por novas turmas. Estas instituições, como também os cursos livres apresentados na sequência, vivenciam mudanças de público, no qual profissionais já qualificados em outras carreiras buscam as aulas como forma de passatempo. $O$ interesse desses profissionais sempre existiu e de certa forma ajuda a manter os cursos em funcionamento.

\section{Cursos Livres}

Os cursos livres são opções oferecidas pelos ateliês, escolas e espaços de aprendizagem que se encontram espalhados por todo o estado do Rio de Janeiro. Estes cursos, geralmente de curta duração, ou de acordo com o

\footnotetext{
159 Programação completa dos cursos oferecidos na área de design de joias pelo SENAC-Rio. Disponível em: <http://www.rj.senac.br/cursos/design-de-joias>. Acesso em: 20 de novembro de 2015.

160 Localizada na Rua Pompeu Loureiro, 45. Copacabana - Rio de Janeiro.

161 Projeto pedagógico do curso Aprendizagem Profissional Comercial em Serviços de Ourivesaria. Disponível em:< file://C:/Users/Ana/Downloads/Aprendizagem\%20em\%20Ourivesaria\%20(1).pdf >. Acesso em: 20 de novembro de 2015.
} 
progresso do aluno, podem servir também como complementos de uma formação superior ou simplesmente como a primeira via de contato, ainda que descompromissada, com o oficio da ourivesaria. Com aulas $100 \%$ práticas, os interessados não precisam apresentar nenhum tipo de formação.

Os cursos livres aqui apresentados estão organizados em ordem alfabética e foram selecionados através das webs sites da AJORIO ${ }^{162}$ e do Portal Joia BR ${ }^{163}$, sendo eles:

Andréa Nicácio - Localizado em Copacabana, o ateliê que antes se chamava Espaço Expressão, agora receber o nome da própria professora e designer de joias Andréa Nicácio ${ }^{164}$. Oferece curso presencial em Design de Joias, em que o aluno desenvolve sua habilidade em exercícios de criatividade e práticas de representação bidimensional, passando do desenho planificado de peças como colares e brincos as técnicas de perspectivas para anéis e alianças. Aulas de Rhinoceros aplicado ao Design de Joias são ministradas por professores convidados e nas modalidades: básica e avançada. $O$ ateliê também oferece um curso online, com módulos e exercícios comentados pela professora. Com duração de quatro meses e apostila disponível para impressão, o aluno poderá marcar um encontro virtual e esclarecer suas de dúvidas.

Ateliê Lívia Canuto - Em seu ateliê no Leblon, a designer de joias e professora Lívia Canuto montou sua Escola de Ourivesaria ${ }^{165}$, onde há mais de 10 anos, "ensina a arte da ourivesaria com design e identidade". Cursos para quem pretende iniciar uma carreira e confeccionar suas próprias joias como os de Ourivesaria Básica e posteriormente a avançada, com carga horária de 120 horas cada; Ateliê Livre e Workshop Joia - Construindo uma Identidade, com carga horária de 24 horas, para alunos que já possuem algum tipo de experiência e procuram por uma orientação específica, tanto na construção de uma determinada peça quanto no desenvolvimento de um projeto diferenciado; Workshops de Modelagem em Cera para iniciantes, com carga horária de 24 horas, e Modelagem 3D, com carga horária de 36 horas, afim de proporcionar

\footnotetext{
162 Lista de cursos da AJORIO.

Disponível em:<http://www.sistemaajorio.com.br/site/index.php/servicos/cursos-profissionalizantesmainmenu-61>. Acesso em: 10 de setembro de 2015.

${ }_{163}$ Lista de cursos do Portal Joia BR. Disponível em:< http://www.joiabr.com.br/cursos/rj.html >. Acesso em: 10 de setembro de 2015.

${ }^{164}$ Vídeo apresentação. Disponível em:< http://www.andreanicacio.com.br/>. Acesso em: 10 de novembro de 2015.

165 A Escola de Ourivesaria e os cursos oferecidos pela Lívia Canuto. Disponível em:< http://www.liviacanuto.com/escola >. Acesso em: 20 de novembro de 2015.
} 
aos alunos uma ampliação de seus conhecimentos e contato com as novas tecnologias utilizadas para a produção de joias. A escola conta com o auxílio de profissionais com experiência do mercado e que complementam o quadro de professores.

Atelier Mourão ${ }^{166}$ - Com aproximadamente 30 anos de funcionamento, o Atelier Mourão é considerado o mais tradicional espaço destinado ao ensino da ourivesaria no Rio de Janeiro. Fundado por Caio Mourão ${ }^{167}$ (1933-2005) e localizado em Ipanema, bairro nobre da Zona Sul, há 20 anos está sob o comando de Paula Mourão, primogênita, que seguindo os passos de seu pai, também se aventurou pelo ofício da criação e confecção de joias. Paula enquanto professora mantem viva a filosofia de Caio Mourão, estimulando a liberdade criativa e a busca da individualidade expressa através dos trabalhos de cada um de seus alunos. O carro chefe do ateliê é o Curso de Joalheria ${ }^{168} \mathrm{com}$ duração estimada entre 8 e 12 meses, onde os exercícios práticos iniciam com as técnicas básicas de ourivesaria passando gradativamente às mais avançadas e sendo realizadas respeitando o ritmo individual de cada aluno.

Espaço Rita Santos / Escola de Joalheria ${ }^{169}$ - Inaugurado em 2005, é uma empresa que nasceu a partir de um projeto empreendedor desenvolvido pela Incubadora de Design de Joias, com o apoio do Instituto Gênesis ${ }^{170}$ da PUC-Rio. Em conjunto com a escola foi criado um espaço destinado à divulgação e comercialização das peças desenvolvidas pelos alunos, o Espaço Rita Santos Artistas $^{171}$. Localizado no bairro do Flamengo, sobre o comando da professora e designer de joias Rita Santos, tem como foco principal o ensino da joalheria autoral, oferecendo cursos para iniciantes, com o de Fundamentos da ourivesaria a Ourivesaria Avançada, passando por técnicas de Modelagem em Cera básica à avançada, Esmaltação a fogo e Cravação de gemas.

\footnotetext{
${ }_{167}^{166}$ A grafia da palavra foi apresentada de acordo como é apresentada.

167 Para saber mais sobre Caio Mourão acesse o site do Atelier Mourão. Disponível em:< http://www.ateliermourao.com.br/caio_mourao.html>. Acesso em: 20 de novembro de 2015. Ou em notícias da AJORIO. Disponível em:< http://www.sistemaajorio.com.br/site/index.php/entidades2/notas-mainmenu-27/23-caio-mourin-memoriam >. Acesso em: 20 de novembro de 2015.

${ }^{168}$ Cursos Atelier Mourão. Disponível em:< http://www.ateliermourao.com.br/cursos.html >. Acesso em: 10 de novembro de 2015.

${ }^{169}$ Cursos Espaço Rita Santos.

Disponível em: < http://www.espacoritasantos.com.br/\#!cursos/c14ak >. Acesso em: 20 de novembro de 2015.

170 Instituto Gênesis. Disponível em: < http://www.genesis.puc-rio.br/>. Acesso em: 20 de novembro de 2015.

${ }_{171}$ Espaço Rita Santos - Artistas. Disponível em: < http://www.espacoritasantosjoias.com.br/>. Acesso em: 20 de novembro de 2015.
} 
EBJ / Escola Brasileira de Joalheria - Inaugurada em julho de $2015^{172}$, a novata escola que está localizada no "prédio mais charmoso de Ipanema"173, possui parceria com o IED Rio - Instituto Europeu de Design e com o blog Joialerismo. Idealizada pelas professoras e designers de joias Livi Pires e Luana Moss, ambas com experiência em ourivesaria. A escola abre suas portas com o propósito de impulsionar o campo joalheiro do Rio de Janeiro, através da oferta de cursos direcionados ao aprendizado das técnicas tradicionais do ofício, com a oferta de aulas de Ourivesaria básica, Ourivesaria avançada e Modelagem em Cera. Técnicas milenares como a filigrana, a esmaltação e a cravação de gemas em metal também são oferecidas, igualmente as aulas de desenho técnico, ilustração de joias e introdução à gemologia, por professores e especialistas convidados. A EBJ ${ }^{174}$ oferece aos seus alunos um diferencial diante dos demais cursos livres existentes no mercado. Além dos cursos práticos direcionados à criação, desenvolvimento e produção de joias, existe também a preocupação de como esse aluno, futuro empreendedor, irá apresentar seu trabalho no mercado e assim, questões que envolvem desde a elaboração do logotipo, posicionamento estratégico, embalagens, material de papelaria, web site e loja virtual, fazem parte dos planos da escola, e que também, incentiva a participação no evento Joalerismo | Expo, criado para divulgar e impulsionar os novos designer o mercado carioca.

Walter Leite ${ }^{175}$ - Desde 1955, o gemólogo graduado pelo GIA - Gemological Institute of America, oferece seus serviços de classificação e certificação de gemas coradas e diamantes ao campo joalheiro. Conceitos de introdução à gemologia como também a identificação e classificação de pérolas, diamantes e gemas de coloridas lapidadas, são ensinados através de workshops práticos, com duração aproximada de 2 horas e material impresso para acompanhamento das técnicas.

Todos os cursos livres desta relação, com a exceção do gemólogo Walter Leite, são ministrados por designers de joias, que além da criação, produção e

\footnotetext{
172 EBJ. Notícias da inauguração. Disponível em: < http://curtanegocios.com.br/?p=131/>. Acesso em: 20 de novembro de 2015. Ou em matéria de Heloisa Tolipan, 2015. Disponível em: < http://www.heloisatolipan.com.br/quotes/recem-inauguradas-em-ipanema-a-escola-brasileira-dejoalheria-e-a-escola-de-design-da-candido-mendes-prometem-maior-integracao-entreprofissionais-da-area/>. Acesso em: 20 de novembro de 2015.

${ }_{173}$ Rua Maria Quitéria 121, sala 201 - Ipanema / Rio de Janeiro. Telefone de contato: 32593164.

174 Disponível em: < http://www.ebj-rio.com/p/sobre-escola.html >. Acesso em: 20 de novembro de 2015.

${ }^{175}$ Gemólogo Walter Leite. Disponível em: < http://www.realgemslab.com.br/cursos.html >. Acesso em: 22 de novembro de 2015.
} 
comercialização de suas peças, garantem uma renda extra com a oferta destes cursos em seus próprios locais de trabalho. Outro ponto a ser observado é quanto à localização, onde todos os ateliês estão situados em bairros da Zona Sul carioca, considerados elitistas, representando assim uma distinção para seus alunos/clientes.

\section{Educação a Distância - EAD}

A educação a distância é uma modalidade de ensino em crescimento no Brasil, e que na grande maioria dos casos, depende dos meios e das tecnologias de informação e comunicação como ponte entre alunos, professores e as plataformas de ensino. Segundo a ABED - Associação Brasileira de Ensino a Distância, o material didático poderá ser disponibilizado por meio de rádio, satélite ou correio, além da internet, já citada e normalmente utilizada. Através deste modelo de ensino, o aluno terá maior flexibilidade para acessar o ambiente de aprendizagem e de acordo com a sua disponibilidade de horário, dia e local, cumprir as tarefas e realizar as avaliações.

No campo joalheiro, o curso Andréa Nicácio, conforme mencionado, era o único a oferecer aulas de desenho e criação de joias na modalidade EAD. Porém, a internet é um universo sem limites e na busca por novos cursos, encontramos o de gemologia oferecido pelo INETEP - Instituto Nacional de Educação, Tecnologia e Pesquisa. Este curso, também na modalidade EAD, tem como foco principal a capacitação de mão de obra qualificada e a divulgação das ciências da terra e das nossas riquezas minerais. Coordenado pelo professor José Humberto Ludice, com carga horária de 60 horas, dividido em 12 aulas, é direcionado a estudantes do ensino médio e superior e aos demais interessados no assunto, como colecionadores de gemas, técnicos em mineração, comerciantes e designers joias, entre outros.

Independente do tipo de curso, sendo ele de nível superior, profissionalizante, livre ou EAD, a habilidade manual que os alunos desenvolvem na bancada produzindo suas as peças, ou no sobre o papel registrando as suas ideias, representam etapas importantes e que complementam o seu trabalho de criação.

Além de tudo que é ensinado, a sala de aula e/ou a oficina são espaços para realização de experiências, trocas e oportunidades. Pode ser o local em que o aluno tenha seu primeiro contato com o oficio da joalheria, como também contato 
com outros profissionais do campo, construindo uma rede de relacionamentos que poderá ser útil em ocasiões futuras.

Os designers empreendedores consideram os cursos, principalmente os de curta duração, como um meio de se manterem atualizados com as mudanças do campo. Geralmente frequentam palestras, workshops e seminários gratuitos oferecidos pelos institutos e pela associação de classe que representam o setor, e eventos de moda nos quais observam as tendências para as próximas coleções. Quanto aos gestores das empresas atuantes no campo, são raros os casos em que esses participam de cursos ou encontros promovidos pelo setor, sem que haja alguma intensão por trás da sua presença. Já os profissionais envolvidos diretamente com a fabricação das peças, também não participam, e ao mesmo tempo em que não demonstram interesse, alegam não terem tempo disponível para interromper os seus trabalhos e comparecer a esses encontros. Ficando os designers e os novos interessados pelo setor de joias, folheados e bijuterias, a responsabilidade pelo quórum destes cursos, palestras, workshops e demais encontros promovidos pelo campo.

\section{4}

\section{Os designers e suas relações com o cenário joalheiro carioca}

Os designers empreendedores, ou aqueles que compõem as equipes de criação/design das empresas que comercializam e/ou fabricam para o campo, estão no centro da cadeia produtiva joalheira carioca. Podemos assim dizer, que estes designers podem vir a se relacionar com profissionais dos mais diversos segmentos dentro do campo $^{176}$ para desenvolverem o seu trabalho. Desde a fabricação das mercadorias através do contato direto com os ourives, lapidários, cravadores e fundidores, por exemplo; passando pelos educadores e instrutores técnicos das instituições de ensino; pelos profissionais que atuam diretamente ou indiretamente nas entidades e associações de classe, como palestrantes e pesquisadores do campo; vendedores; ou diretamente em contato com os próprios donos das empresas, os designers estabelecem conexões com as etapas de criação, produção, divulgação e a comercialização das mercadorias oferecidas pelo setor. Sendo assim, pesquisar um pouco mais sobre estes vínculos e se aproximar destes designers foi importante para tentar entender

\footnotetext{
${ }^{176}$ Ver: Figura 3 - Mapa do Campo Joalheiro do Rio de Janeiro, p.48.
} 
como eles se sentem em relação ao campo, quais são os seus interesses, desejos e limitações.

Para o desenvolvimento desta etapa da pesquisa foram realizadas entrevistas ${ }^{177}$, em três grupos distintos, para os quais os critérios usados para e seleção dos entrevistos foram os seguintes: i) Grupo A, formado por designers empregados ou que já trabalharam em alguma joalheria que produz sua própria mercadoria ou fabricante de joias, folheados ou bijuterias no estado do Rio de Janeiro, com tempo de atuação maior ou igual a cinco anos, e formação superior em design de produto ou área similar; ii) Grupo B, formado por designers empreendedores que possuem pelo menos um ponto de venda físico (loja física) no estado do Rio de Janeiro, e por designers empreendedores que desenvolvem um trabalho autoral e que não possuem um ponto de venda físico, mas comercializam suas peças via sites de comércio eletrônico ou durante eventos e feiras sazonais do setor; iii) Grupo C, formado por profissionais responsáveis pela equipe de criação/design das empresas que praticam a venda ao cliente final/varejo e/ou das empresas produtoras de joias, folheados e bijuterias, com pontos de venda ou escritórios localizados no estado do Rio de Janeiro e que começaram suas atividades antes ou durante a década de 1990, período em que a economia brasileira recebeu incentivos para se mostrar competitiva perante a abertura da concorrência internacional. O aumento da produtividade interna do país impactou diretamente no mercado de trabalho, oferecendo maiores oportunidades para profissionais com qualificação. Neste momento, o setor joalheiro no Rio de Janeiro se mostrava aquecido, fortalecendo as empresas existentes e despertando o interesse de novos investidores no comércio e/ou na fabricação de mercadorias - joias, folheados e bijuterias -, e também, a inclusão de uma nova geração de profissionais, os designers empreendedores.

A identidade dos participantes foi preservada, pois este "acordo" de confiança fez com que os envolvidos se sentissem mais confortáveis em abordar questões delicadas que acontecem dentro das empresas e nas relações entre os próprios profissionais do campo. Apesar de muitas tentativas em estabelecer contato para a realização das entrevistas, o Grupo C - profissionais responsáveis pelas equipes de criação/design das empresas comerciantes e/ou fabricantes de joias, folheados e bijuterias - foi o que mais apresentou resistência, mesmo que para uma resposta negativa sobre a sua participação. Ao contrário do que se

\footnotetext{
${ }^{177}$ As perguntas formuladas para a realização das entrevistas estão disponibilizadas no Anexo.
} 
esperava, depois de tanta repulsa e indiferença dos membros desse grupo, apenas um deles se mostrou atencioso e disposto a ajudar, indicando, inclusive, alguns nomes para compor a lista de entrevistados.

Este entrevistado do Grupo C é um empresário do setor que desenvolve, fabrica e revende joias em seu estabelecimento. Ele relatou que só percebeu a importância de um "design bem feito" quando contratou um designer de produto freelancer ${ }^{178}$ para executar um projeto temático de vitrine em sua loja, e que antes contratava profissionais que "vendiam a ideia de fazer design", mas que na verdade "replicavam o que outras empresas já faziam" sem querer saber das suas reais necessidades. Os resultados da nova vitrine chamaram a atenção dos lojistas ao redor e do público que circulava pelos corredores do shopping, trazendo novos consumidores e refletindo diretamente no volume de vendas da empresa.

Depois dessa experiência o entrevistado $\mathrm{C} 1$ passou a trabalhar com designers de outras habilitações ${ }^{179} \mathrm{e}$, há 10 anos, montou uma equipe de designers autônomos, na qual todos juntos atuam no desenvolvimento de novos produtos joias e brindes para eventos em que a marca participa -, vitrines e expositores, embalagens e material de papelaria, campanhas de marketing e visual merchandising à atualização do layout do site da própria empresa. Com orgulho o entrevistado C1 declarou: "temos a certeza que é impossível trabalhar sem design" e em entrelinhas deixou transparecer que a remuneração da sua equipe não está abaixo dos padrões praticados no mercado.

Questionado sobre a possibilidade da contratação efetiva da equipe e assim, ter exclusividade sobre o trabalho desses profissionais, o entrevistado $\mathrm{C} 1$ falou que isso seria impossível devido aos impostos brasileiros e outras questões trabalhistas, que não cabem ser mencionadas no momento. Relatou que a equipe é unida, uma vez em que todos já se conheciam, pois em algum momento já haviam trabalhado juntos em outras empresas do setor. Um designer indicou o outro e assim o grupo foi formado. Este tipo de comportamento nos prova como os bons relacionamentos que foram construídos entre os pares do campo se perpetuam, e se mostram indicadores interessantes para novas oportunidades.

\footnotetext{
178 Freelancer - termo em inglês para designar um profissional autônomo, vem vínculos empregatícios.

${ }^{179}$ Comunicação Visual, Moda e Mídias Digitais.
} 
O entrevistado $\mathrm{C} 1$ tem por hábito lançar pequenas linhas (8 a 15 peças) voltadas para datas comemorativas, como por exemplo, o Dia das Mães, Dia dos Namorados e Natal, acreditando serem essas as ocasiões mais importantes para as vendas no comércio varejista. Ele também observou que seus concorrentes lançam novas coleções para essas festividades e os clientes ficam ansiosos pelas novidades. Desde a fundação da empresa, por um membro de sua família, ele acredita que já desenvolveram mais de 1.600 peças, entre colares, brincos, anéis e pulseiras em ouro, diamantes e pedras preciosas, de coleções a modelos exclusivos para clientes. Apesar de ter mencionado possuir e de achar importante a presença de um designer especialista em joias compondo a sua equipe, preferiu não se aprofundar nesta questão. Explicou que a estratégia de marketing traçada pelo grupo, que inclui esse profissional, é de transparecer para o público consumidor da empresa a ideia de que ele próprio, o dono, seria o responsável pelo design das joias, dedicando assim, boa parte do seu tempo às criações da marca.

Muitas empresas, principalmente as familiares, quando contratam designers para compor sua equipe de criação ou encomendam desenhos dos designers autônomos, como no caso relatado a cima, têm por costume não divulgar o nome dos criadores, promovendo e comercializando as peças sem o devido crédito de quem as projetou. Esta conduta foi relatada, por 6 dentre os 7 componentes entrevistados do Grupo A - designers empregados ou que já trabalharam, por durante 5 anos ou mais, em uma empresa do campo joalheiro no Rio de Janeiro - e considerada como uma prova de insegurança por parte dos donos das empresas. O entrevistado A1 relatou, que mesmo ciente de trabalhar para uma determinada marca e de buscar agir de forma profissional, com o tempo se mostrou contrariado ao receber o título de "assistente", pois essa denominação, para ele, desmerecia o seu trabalho.

\footnotetext{
"Eu nunca fui apresentado pelo meu chefe como designer ou mesmo como estilista da empresa, se fosse o caso, e sim como assistente... Assistente já existia! Era quem ligava para os ourives, por exemplo, e eu estava envolvido diretamente com a criação dos produtos da marca... Nós éramos amigos, trabalhávamos juntos e entre a gente existia uma simbiose de criação... Mas parecia que ele me escondia!" (Entrevistado A1, 2016).
} 
Para o Grupo $A^{180}$, manter uma relação profissional com o chefe e a equipe seria o ideal, mas no caso deles, que trabalharam ou ainda trabalham diretamente com os próprios donos do negócio, isso requer muita desenvoltura. Fatores da vida pessoal se envolvem com o profissional ao ponto do designer, muitas vezes, achar que é considerado como um membro da família, inflando seu ego, e fazendo com que decisões importantes sejam tomadas pela emoção, e não pela razão, como por exemplo, na escolha de um tema de sua preferência a ser desenvolvido em uma coleção. Segundo os relatos, esse comportamento antiprofissional, estimulado pelos próprios gestores/donos da empresa, também gera conflitos e disputa de poder entre os membros do mesmo departamento, e que neste caso, era o de Criação. "Um se sentia mais importante do que o outro", relata o entrevistado $A 2$, transformando o que poderia ser um trabalho em equipe em uma verdadeira competição entre designers. Sendo assim, podemos verificar o despreparo desses gestores, que através de técnicas ultrapassadas de administração familiar, colocam um funcionário contra o outro de modo a estimular uma competição nada saudável, e através de conversas de bastidores, vulgo "fofocas", são informados do que se passa em sua empresa. Estes gestores não investem na consolidação de um trabalho realizado em equipe, e ainda acreditam que o mercado está cheio de designers procurando por uma oportunidade que só eles podem oferecer.

Os designers do Grupo A acreditam que "ganhavam menos do que mereciam" e todos se mostraram insatisfeitos em relação à remuneração recebida pelo seu trabalho. Relataram que o crédito dado às criações seria uma forma de reconhecimento ao seu empenho na empresa, ou até mesmo uma compensação pelo o déficit do lado financeiro. Todos tiveram problemas com reajustes salariais, e mais ainda os que aceitaram a proposta de começar recebendo baixas quantias, talvez como forma de garantia de emprego, pela demonstração do seu potencial. Muitas empresas se valem deste argumento na hora da contratação, mas depois, caindo no campo do esquecimento, não honram com o prometido fazendo com que o designer, ao requerer por seus direitos, passe por situações constrangedoras, conforme narrado pelos entrevistados A3, A4 e A5, que vivenciaram esse problema. Isso reforça o pensamento egocêntrico dos empresários do campo que acham que suas empresas são "o único lugar do

\footnotetext{
${ }^{180}$ O Grupo A é composto por 7 entrevistados, deste 6 de seus componentes trabalharam, sendo que 1 ainda está empregado na mesma empresa, porém em períodos diferentes.
} 
mundo que o designer de joias tem para trabalhar" e assim o fazem, segundo seus interesses e suas vontades.

No Grupo B - designers empreendedores - este tipo de situação não acontece. Donos do próprio negócio, geralmente batizado com o próprio nome e/ou sobrenome, eles desenvolvem e assinam suas peças, linhas e coleções. Enquadrados no regime do $\mathrm{MEI}^{181}$, os 8 entrevistados desse grupo, independentemente de possuírem uma loja física ou de comercializarem suas peças diretamente com os consumidores e em sites destinados ao e-commerce, relataram que dividem o tempo destinado ao trabalho de modo a cumprir com todas as obrigações do negócio, mas que gostariam mesmo era de ter mais disponibilidade para se dedicarem mais à criação de seus produtos, como, na visão deles, acontece com os designers dentro dos departamentos de criação das joalherias.

"A administração do negócio e a produção são as tarefas que ocupam a maior parte do meu tempo, acredito que chega a ser quase metade dele. O restante é dividido entre as outras partes, sendo, em ordem, não exatamente de prioridade, mas de necessidade: marketing, vendas, criação e relacionamento com o cliente." (Entrevistado B1, 2016)

Todos os designers do Grupo B declararam que terceirizam pelo menos algum tipo de serviço, como a fundição de peças, por exemplo, podendo atingir até todas as etapas envolvidas com o processo de produção de suas joias. Este grupo se mostrou insatisfeito com a qualidade da mão de obra apresentada pelo setor no Rio de Janeiro e a grande reclamação ficou com a falta de confiança, principalmente nos ourives e cravadores, que sem a menor ética profissional, não cumprem com os prazos estabelecidos de entrega das mercadorias, e ainda sem o menor constrangimento, reproduzem cópias de peças, inclusive de marcas famosas, para clientes mal-intencionados. Essas condutas mostram como a ausência de uma formação profissional, mesmo que técnica, dos setores envolvidos com a fabricação dos produtos interfere no todo. Uma peça mal executada significa retrabalho, que consome mais tempo, podendo envolver desperdício de matéria-prima gerando custos, impactando nos prazos de entrega e na expectativa do cliente em receber seu produto conforme o combinado.

A cópia de mercadorias é uma preocupação constante entre os entrevistados dos Grupos A e B, porém os próprios, por desacreditarem da eficácia das leis

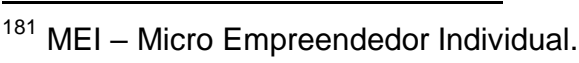


brasileiras, não buscam os órgãos competentes para efetuar o registro de suas peças. Relataram que o custo e a burocracia que envolve os registros de Desenho Industrial, realizado no INPI $^{182}$, ou o de Direito Autoral conferido pela $E B A^{183}$, mencionados na introdução dessa dissertação, são caros e se realizados, seus valores impactariam no custo final dos produtos, inviabilizando sua venda. Diante disso, apenas 2 entrevistados comentaram que utilizam formas extraoficiais para produzirem provas e registrar a data da criação de uma peça. O entrevistado B3 acredita que "lacrar um envelope contendo os desenhos das suas criações e enviá-lo para o seu próprio endereço", com o carimbo dos Correios, é "uma prova que deverá ser guardada intacta e só violada por uma autoridade" (juiz), que julgará válida ou não, mediante as condições apresentadas em um processo de plágio. Concluímos que mesmo sendo uma questão importante, com os custos reduzidos para as empresas MEI e burocracias simplificadas com os registros via site do INPI, por exemplo, o tipo de proteção oferecida pelas leis brasileiras não é suficiente para que os entrevistados se sintam abraçados por ela, passando a praticá-la no seu dia a dia.

Os entrevistados do Grupo B, designers autônomos, buscam expressar em seus produtos características da própria identidade de modo que a forma, o material e a textura de suas peças sejam percebidos como elementos diferenciadores. Eles também produzem peças para serem lançadas em datas comemorativas, mas $80 \%$ dos entrevistados deste grupo declararam que as encomendas exclusivas feitas para particulares representam o "ganha pão" diário e que por isso, investem em um atendimento diferenciado aos seus clientes, oferecendo peças únicas e desenvolvidas de acordo com as suas necessidades. Os clientes "percebem que o design/criação tem um papel fundamental" e muitos fazem questão de uma aproximação maior com o designer e "se sentem prestigiados por isso", segundo relatos do entrevistado B2, que também foram mencionados pelos entrevistados B1, B3, B6 e B8.

Quanto à formulação do preço das mercadorias, apenas 2, no conjunto dos 8 entrevistados do Grupo B, declararam que além dos custos variáveis com matéria-prima, mão de obra profissional terceirizada, embalagens, porcentagens da taxa do cartão de crédito entre outros, incluem, também, uma taxa fixa para cobrir gastos de funcionamento do negócio, como por exemplo, deslocamento e

\footnotetext{
182 Instituto Brasileiro de Propriedade Industrial (sic).

${ }^{183}$ Escola de Belas Artes da Universidade Federal do Rio de Janeiro, UFRJ (sic).
} 
serviços de telefonia e internet. Ninguém declarou que na relação de itens que compõe os custos variáveis poderia ser incluído um valor pela quantidade de horas destinadas ao trabalho de criação. "É difícil precificar algo que faço com prazer" declarou o entrevistado $B 7$, e assim concluímos que o tempo gasto com o desenvolvimento/criação das peças não é computado, pois é percebido como dedicado a uma atividade que gera prazer e não como trabalho, um "momento de lazer" no qual burocracias não são envolvidas.

Todos os entrevistados dos Grupos A e B possuem formação superior, sendo que 5 são graduados em Design - Projeto de Produto, 8 em Design de Produto Joia e 2 em Arquitetura. Todos frequentaram cursos livres oferecidos para 0 setor como o objetivo de aprimoramento profissional. Eles afirmaram que é essencial o conhecimento da matéria-prima, principalmente dos metais e das gemas, e dos processos de fabricação, incluindo as novas tecnologias, para desenvolver peças criativas e passíveis de execução. Os entrevistados B2 e B7 para se atualizarem, estão sempre à procura de novos cursos, declarando também, ser essa uma das formas de manter contato com outros profissionais do campo.

\footnotetext{
"Sentar na bancada e aprender como seu faz uma joia é fundamental. Mesmo que você não vá trabalhar com a produção, você precisa desse conhecimento para criar, e também para explicar os detalhes da joia para um profissional que poderá ser contratador para produzir as suas peças." (Entrevistado B2, 2016)
}

Enquanto os entrevistados do Grupo A se mostraram insatisfeitos com a relação de trabalho ofertada pelas empresas do campo no Rio de Janeiro, os componentes do Grupo B, apesar de terem reclamarem do acúmulo de funções, se sentem realizados enquanto designers para "criar e ver a criação realizada". Porém, ainda sentem falta de ajuda, de orientação em como lidar com as etapas administrativas, como a construção das planilhas de custo das peças, emissão de notas fiscais ou mesmo o preenchimento da autorização e documentação específica para participação em eventos do setor. A maioria foi buscar apoio no SEBRAE, e apenas um, o entrevistado B1, contou com a orientação de um familiar com experiência em administração de empresas para abrir e começar a conduzir o seu negócio. A falta de comprometimento com essas etapas administrativas e tão importantes para o gerenciamento do negócio é percebida claramente, pois apenas 3 , entre os 8 entrevistados relataram possuir um banco de dados de suas criações e souberam dizer quantos peças já haviam produzido até o momento da realização da entrevista. $O$ restante, nem tentou ariscar um 
número aproximado e quando questionados sobre o motivo de não possuir um registro, alegaram a falta de tempo ou de ajuda para com essa tarefa. $O$ entrevistado B8 lembrou que sempre tem problemas ao refazer os "pés de brincos" ${ }^{184}$ que são perdidos por clientes. Por não ter esse banco de dados e nunca saber em que lugar anotou os dados sobre a fabricação da tal peça, acaba sempre produzindo um novo par. Ele finalizou dizendo: "fazer banco de dados pra ontem!".

Após análise dos pontos principais abordados pelas entrevistas, um dos fatores investigados ao nível da curiosidade é agora apresentado. Nenhum entrevistado, exceto o único do Grupo $\mathrm{C}$, possui um familiar ou alguém próximo ao seu convívio que exerça ou tenha exercido alguma função no campo joalheiro. Como de costume, o ofício da ourivesaria que tinha o seu aprendizado passado de "pai para filho" e perpetuando a profissão em um ambiente familiar, ganhou espaço dentro das instituições de ensino, e em meados da década de 1990, atraiu novos profissionais e interessados no produto joia. Os participantes desta entrevista, através de reportagens em jornais e/ou propagandas de divulgação dos cursos superiores, profissionalizantes e livres - oferecidos no início dos anos 2000, descobriram o ofício da ourivesaria, quando a profissão passou a ser mais divulgada e o mercado se fazia promissor, despertando o interesse e a formação de novos profissionais. Depois de tantos altos e baixos do mercado, estes continuam oferecendo seus produtos - joias, folheados e bijuterias - acreditando que o design é o fator que confere o diferencial de suas peças e que seus consumidores estão cientes da sua importância e buscam por isso.

Sendo assim, ao formular uma síntese com os resultados destas entrevistas, concluímos que nenhuma ação foi efetivamente feita por estes designers que anseiam por um campo joalheiro próspero e mais profissional no Rio de Janeiro. O tempo passou e apesar das mudanças econômicas que influenciaram diretamente o setor, provocando uma queda na sua produtividade, ou mesmo com a tímida inserção das novas tecnologias de criação, produção e divulgação das peças, verificamos que o panorama do cenário joalheiro carioca continua o mesmo. Nada mudou no campo e seus espaços de circulação e legitimação, formados pelas empresas, pelas entidades que representam o setor, pelos espaços e veículos de comercialização e divulgação, pelas instituições de ensino

\footnotetext{
184 "Pé de brinco" é o nome dado para um dos pares que compõe o par de brincos, ou seja, os brincos possuem dois "pés", um direito e o outro esquerdo, geralmente iguais, mas com a forma espelhada.
} 
e pelos profissionais autônomos atuantes na produção das mercadorias, dentre os quais o designer pode ser enquadrado, continuam operando dentro dos próprios interesses e privilegiando os grupos dos quais pertencem. 


\section{O design para o campo da joalheria}

O entendimento sobre isso que é o design pode ir além da sua tradução literal para o português - projeto. Essa noção pode estar presente em quase tudo que foi pensado e produzido pelo homem desde o início da história da humanidade. Observado por Forty (2007), a maioria dos estudos apresentados nas últimas cinco décadas sobre o design apontam para outro tipo de entendimento: o embelezamento dos objetos como sendo o seu principal objetivo. Outros estudos que empreendeu, também relatados por ele em seu livro Objetos de Desejo Design e Sociedade desde 1750, oferecem outras definições disso que é o design, sendo que a definição empregada hegemonicamente sobre o design é que ele é uma prática muito singular: "um método especial de resolver problemas", contudo e ainda, Forty nos oferece uma reflexão muito interessante como desdobramento da dimensão estética e que nos faz pensar: poucas são as teorias que mostram a sua relação com o lucro ou com a preocupação de propagar algum tipo ideia (FORTY, 2007, p.11), assim a noção que os designers empregam em relação ao objeto que produzem não é apenas uma questão filosófica em relação ao belo, mas envolvem uma particularidade: em que medida isso que é tido por belo pode fazer com que esse objeto seja desejado, isto é, que ele seja de alguma forma ambicionado por uma consumidor.

Do mesmo modo que Forty, Latour descreve que a noção de um objeto com design também esteve relacionada com o ato da transformação estética da forma dos objetos, porém sem promover alteração em suas funções. Em particular, o design seria o acabamento, o "verniz formal"185, a capa que revestiria os projetos realizados pelos profissionais pertencentes às categorias mais distintas da sociedade como, por exemplo, a dos cientistas e dos engenheiros. O que era entendido como design, com o tempo, se ampliou de tal

\footnotetext{
${ }^{185}$ Latour, B. A Cautions Prometheus? A few steps towards a philosophy of Design. Palestra de abertura do encontro Networks of Design da Design History Society. Falmouth, Cornwall, 03 de setembro de 2008. Disponível em:< http://www.bruno-latour.fr/sites/default/files/112-DESIGNCORNWALL-GB.pdf>. Acesso em: 03 de março de 2017.
} 
maneira, que hoje, não conseguimos mais definir com precisão os seus limites (LATOUR, 2008).

No campo da joalheria verificamos que a noção hegemônica sobre isso que é design, comunga com a crença de que o design é responsável principalmente pela estética dos objetos, mas trata-se na verdade de uma noção muito pragmática e objetiva, tal como Forty observou. Assim, quanto mais bela for a joia, quanto mais sedutora for a sua forma, maior será o seu poder de encantamento sobre os consumidores, daí por que investir em design pode ser um bom negócio para os joalheiros. Portanto não se trata de uma discussão puramente estética sobre a beleza tal como os filósofos gregos gostavam de fazer ou moderna e gratuita noção kantiana e igualmente idealista, mas de uma estética utilitarista que visa a produção da mais valia. As peças fabricadas, divulgadas e vendidas pelo campo - joias, folheados e bijuterias -, ajudam a movimentar a economia do estado, gerando emprego e renda para os todos os envolvidos em seus processos de criação, produção e comercialização. Por outro lado, também podem ser classificadas como mercadorias supérfluas e de uso diretamente ligado a um capricho humano. Através do emprego de matériasprimas nobres, representando a condição social de seus donos, ou simplesmente interagindo com as vestimentas da moda local e traduzindo o estilo que é a tendência do momento, que a bem da verdade, temos grande dificuldade de afirmar o que isso significa realmente.

A partir das entrevistas realizadas com os designers atuantes no campo joalheiro do Rio de Janeiro, mapeamos suas observações e expectativas em relação ao seu próprio trabalho e ao mercado em que atuam. O emprego do design nas peças produzidas por esses profissionais, tal como vimos, é avaliado apenas enquanto sua importância econômica, enfim, o que é percebido pelos agentes do campo e não pela estética de suas formas, na qual as joias poderiam ser classificadas subjetivamente como boas ou ruins. Essa classificação circunscrita à condição estética idealista é uma questão que abre espaço para novas discussões sobre os produtos criados e produzidos pelo campo joalheiro e no momento, julgamos que não cabe a sua abordagem para discussão nesse trabalho. A nossa ação foi destinada a entender, isto é, traduzir em poucas palavras, em que medida a dimensão estética, a forma da joia, pode influenciar positivamente um consumidor de modo que ele passe a comprar cada vez mais joias. 


\section{1}

\section{A importância do design para o setor joalheiro no Rio de Janeiro}

Considerado a segunda maior economia do Brasil, o estado do Rio de Janeiro possui um parque fabril composto por 10 distritos industriais ${ }^{186}$, reunindo empresas dos ramos metalúrgico e siderúrgico, naval, produtos químicos e petroquímicos, automotivos, farmacêuticos, cosméticos, alimentícios, entre outros. Abrigando a maior siderúrgica da América Latina, a CSN - Companhia Siderúrgica Nacional, e mesmo com toda essa diversidade industrial, é no setor terciário que se concentram as principais atividades que movimentam o desenvolvimento econômico fluminense. Este setor responde pelas atividades que envolvem a prestação de serviços e o comércio de bens de consumo, ambiente em que o setor joalheiro concentra a sua maior participação no estado do Rio de Janeiro. ${ }^{187}$

Segundo as expectativas depositadas com os investimentos realizados em obras e melhorias de infraestruturas para receber megaeventos internacionais - Copa do Mundo, em 2014, e as Olimpíadas, em 2016 -, o estado do Rio de Janeiro ficou na mira da imprensa mundial e se tornou objeto de desejo de turistas e de aficionados por esportes. A construção de novos museus, espaços de visitação pública como a revitalização da Zona Portuária, também fizeram parte das transformações culturais, econômica e política vividas pela cidade. Nesse trabalho não nos interessamos em indagar sobre o sucesso ou fracasso que tenha acontecido durante os preparativos, ou mesmo na realização dos eventos ou sobre os seus legados. O que observaremos aqui é o desenvolvimento de um termo muito em voga, digamos assim - a economia criativa - que movimentou o mercado impulsionado pela suposição de que existiria um "desejo" de gerar e comercializar produtos que pudessem representar ou que pudessem traduzir a essência cultural do nosso estado, transformando-a em algo vendável e que no final das contas seria irresistível aos consumidores. Uma espécie de mítica galinha dos ovos de ouro da nossa economia, mas que julgamos ser na realidade uma velha fórmula requentada do "onde se plantando, tudo dá",

\footnotetext{
${ }^{186}$ Dados fornecidos pela CODIN - Companhia de Desenvolvimento Industrial do Estado do Rio de Janeiro, responsável pela implantação e gestão dos distritos industriais no estado.

187 A cadeia de joias, bijuterias e afins no estado do Rio de Janeiro é dividida em: 5,0\% extrativismo mineral; $12,4 \%$ fabricação; $7,1 \%$ comércio atacadista; $67,2 \%$ comércio varejista e $8,3 \%$ serviços relacionados. Dados apresentados pelo Sistema FIRJAN no estudo lançado em 2012, Mapeamento da Indústria Criativa no Brasil - Joias, bijuterias e afins.
} 
mencionado pela primeira vez por Pero Vaz de Caminha ao rei de Portugal justificando os investimentos mercantis que pudessem convencer abastados mercadores a investirem mais no Brasil.

O conceito utilizado para definir o que hoje entendemos por economia criativa é muito discutido e para muitos uma falácia. Ele nasceu na Austrália, em 1994 e originalmente provém do termo: creative nation. ${ }^{188}$ Conforme relatório apresentado pelo primeiro ministro australiano, nesta época, a indústria criativa foi planejada com o objetivo de incentivar e fortalecer a cultura local, tornando-a competitiva mediante às transformações sociais, culturais, econômicas e políticas trazidas com a globalização, isto é, produziu-se a noção ideológica de que uma expressão regional de uma cultura, fosse ela material ou imaterial, poderia ser concretizada como produtora de mais valia, ou então, que essa cultura, singular frente à globalização, poderia ser tomada positivamente e transformada em mercadoria, isto é, que o limão podia ser transformado em limonada. A cidade do Rio de Janeiro e seu povo, entendidos como um produto comercial, onde as praias, a sua alegria contagiante, o sol praticamente o ano inteiro, Carnaval, a feijoada e etc. seriam trampolins para ótimos negócios e geração de riqueza. Ocorre que os megaeventos já aconteceram e a promessa de que a cidade produziria riqueza, parece que só aconteceu para uns poucos, isto é, os mesmos beneficiários de sempre, pois o estado está em ruína administrativa, social e econômica, onde desde a sua universidade ${ }^{189}$, passando pelos postos de saúde e hospitais e incluindo até restaurantes populares, estão sendo fechados por falta de dinheiro para seu funcionamento.

O problema do projeto "economia criativa" é que ele se apresenta como uma espécie de tábua de salvação da lavoura para os desdobramentos da crise econômica de 2008 (Banco Lehman Brothers e "crise das subprimes") e que até os dias de hoje ainda não foram solucionados. Verifica-se que desde os anos noventa do século passado iniciou-se uma transferência dos capitais investidos na economia produtiva e que são radicalmente diferentes da forma como eles eram investidos, a essa política econômica chamada de neoliberalismo onde o setor produtivo ou industrial está sendo praticamente substituído pelo de serviços. Houve um crescimento dos investimentos no capital financeiro enquanto que os capitais investidos no sistema produtivo foram se escasseando. Com isso, verificou-se uma "financeirização" da economia e uma fortíssima baixa

\footnotetext{
${ }^{188}$ Creative nation - terno em inglês que significa: Indústria criativa.

189 UERJ - Universidade Estadual do Rio de Janeiro.
} 
no setor produtivo, sendo que esse, além dos produtos, gera empregos a muitos trabalhadores. E ainda, segundo os economistas marxistas, é o único capaz de produzir riqueza, isto é, capital. Nesse processo investiu-se na noção ideológica de que os serviços, ou a indústria criativa, poderiam produzir a mesma riqueza do que o setor produtivo e ocorre que isso ainda não aconteceu.

A Austrália buscou nesta iniciativa, voltada para as políticas públicas, uma forma de reforçar sua economia perante o cenário mundial, haja vista o fato deste país não estar podendo competir industrialmente com outras grandes potências industriais, especialmente a dos tigres asiáticos e mais tarde com a China. Posteriormente esta estratégia, mesmo que sem priorizar as abrangências sociais e econômicas desejadas, foi propagada em outros países ${ }^{190}$ ao redor do mundo. E quase uma década e meia depois de sua criação, em 2008, foi apresentado pela UNICTAD - Conferência das Nações Unidas sobre Comércio e Desenvolvimento - o primeiro relatório internacioal direcionado ao tema: econonia criativa (SEMENSATO, 2013).

$\mathrm{Na}$ versão em língua portuguesa, lançada em 2010, o relatório Economia Criativa: Uma Opção de Desenvolvimento Viável ${ }^{191}$ apresenta a economia criativa como um conceito novo, ainda em transformação, e que se baseia em ativos criativos para promover: i) a geração de empregos, de renda e ganhos com a exportação; ii) inclusão social e desenvolvimento humano. Englobando questões culturais e socioeconômicas, como se outras economias não o fizessem, a economia criativa é percebida como uma opção viável a ser trabalhada por políticas multidisciplinares e que também promovam ações inovadoras. A interação com as novas tecnologias, com as políticas de propriedade intelectual e com o incentivo cultural do turismo local, representam os principais pilares deste modelo adotado ao redor do mundo, e destacando a indústria criativa como o polo central para o seu crescimento (UNICTAD, 2010, p. 40).

Nos países em que se encontravam em dificuldades de competir industrialmente com outras potências industriais, como o Brasil, questões que envolvem a economia criativa são ainda mais recentes, visto que muitos empresários só ouviram falar sobre ela nos anos que antecederam os megaeventos, e mesmo assim, não sabem definir ao certo o seu papel. Os incentivos governamentais

\footnotetext{
${ }^{190}$ Em 1997 no Reino Unido, depois em Cingapura, no Líbano e na Colômbia.

191 Relatório, versão 2010. Disponível em: < http://unctad.org/pt/docs/ditctab20103_pt.pdf >. Acesso em: 12 de fevereiro de 2017.
} 
aos segmentos que trabalham a criatividade em seus produtos e serviços também só foram divulgados, e a sua maioria, viabilizados para a ocasião. $\mathrm{O}$ vínculo criado com a cultura local foi entendido como o principal argumento para o desenvolvimento da economia criativa, porém a projeção da própria identidade cultural, para si mesmo e para o mundo, é apenas um dos fatores a serem trabalhados por este conceito. Associar a criatividade ao desenvolvimento econômico, de modo que este aconteça simultaneamente ao crescimento cultural da cidade do Rio de Janeiro ainda é um desafio enfrentado no estado.

Segundo levantamento realizado pelo SEBRAE, o Rio de Janeiro possui 107 mil trabalhadores envolvidos com a indústria criativa ${ }^{192}$, atuando em diversos setores da economia, com destaque os segmentos de moda, adornos pessoais, decoração e artesanato, como também, para os que lidam as atividades culturais, turísticas e de entretenimento. O campo do design está relacionado diretamente com esses segmentos, pois trabalha com a criação e o desenvolvimento de novos produtos e serviços, e supostamente está ligado à capacidade de inovar. Tal como vimos mais acima, assim como Forty e Latour defendem, o trabalho realizado pelos designers, principalmente no que se refere à estética das formas, é reconhecido como uma ferramenta competitiva e muito utilizada pelas empresas que buscam destaque no mercado. Enfim, a noção de que se modificarmos aspectos formais dos objetos, entendidos aqui como criação ${ }^{193}$, pode-se obter como resultado a ampliação das vendas e do consumo, isto é, com baixo custo de investimento, pode-se auferir bons lucros.

Complementando essa panorâmica reflexão, a indústria criativa também pode ser apresentada sob dois pontos de vista distintos: um com o foco na produção e o outro no mercado. O primeiro, ao contrário do que se imagina, emprega profissionais de outros campos para compor a sua força de trabalho, além daqueles que já atuam em áreas criativas, como, por exemplo: designers, estilistas, publicitários, marqueteiros, produtores de conteúdo audiovisual, entre outros. Já no segundo, o mercado de trabalho vai buscar por profissionais criativos independentemente de suas áreas, como na engenharia e na administração para o desenvolvimento de projetos originais dentro de seus campos de atuação.

\footnotetext{
192 Dados apresentados pelo Sistema FIRJAN no documento Mapeamento da Indústria Criativa no Brasil, 2014. Disponível em: < http://www.abradi.com.br/wp-content/uploads/2015/05/Mapeamento2014.pdf>. Acesso em: 12 de fevereiro de 2017.

${ }^{193}$ Há que se pensar que o termo criação está sendo empregado de forma irresponsável. O que a indústria deseja é incremento e a maior parte do que é apresentado como criativo é o simples redesenho, muitas vezes epidérmicos tal como a mudança de cores.
} 
Voltada para o setor joalheiro a indústria criativa também pode ser mapeada levando em consideração as duas visões apresentadas. Neste caso, o designer responsável pelo produto é também o profissional capacitado para desempenhar o papel transformador em outras áreas dentro do campo. Expandido seus limites e atuando na criação e/ou na fabricação das peças em conjunto com profissionais de outros segmentos; contribuindo nas áreas responsáveis pela compra de novos insumos e matéria-prima; participando da gestão do negócio com sua experiência, são alguns dos exemplos em que a sua contribuição poderá ser bem recebida. Sendo assim, se tudo ocorrer tal como os economistas neoliberais profetizam e para uma melhor compreensão do assunto, a seguir abordaremos algumas questões sobre: o mercado e seus contratantes; o trabalho de criação e/ou produção realizado pelos designers e a valorização que é dada ao design das mercadorias produzidas pelo setor no Rio de Janeiro. O design dessas joias, folheados e bijuterias, é reconhecido, é importante para o setor joalheiro no Rio de Janeiro?

As empresas que compõem o setor joalheiro no Rio de Janeiro são classificadas, em sua maioria, como microempresas ou de pequeno porte ${ }^{194}$ e apresentam ainda a gestão familiar, relatada nessa pesquisa, como uma de suas principais características. Ser $100 \%$ profissional em um ambiente familiar é tarefa árdua, e que nem sempre é bem executada pelos gestores dessas empresas. Sendo assim, podemos observar dentro do setor que as preferências pessoais do dono interferem diretamente nas decisões estratégicas do negócio, como também, diretamente no design do próprio produto.

O dono, o filho do dono, ou ainda qualquer outro parente, que cresceu dentro deste universo se sente capacitado a desenvolver peças baseadas na experiência vivida dentro da própria empresa, e esta prática, ainda muito comum, acaba se refletindo em produtos corriqueiros e que são oferecidos regularmente no mercado. Correndo o risco de cometer os mesmos erros de seus familiares, fundadores do negócio, ao se aventurarem na criação ou mesmo na produção de joias, estes replicam vícios de condutas consideradas inadequadas, tal como a cópia, mas que ainda são mantidos pelo setor. Acompanhar o que seus concorrentes estão lançando e se basear nisso para

\footnotetext{
${ }^{194}$ Nos dados fornecidos pelo SEBRAE, as empresas que apresentarem receita bruta anual igual ou inferior a $R \$ 360.000,00$ são classificadas com microempresas, e as de pequeno porte são aquelas que possuem sua receita bruta anual superior a $R \$ 360.000,00$ e igual ou inferior é $R \$$ 3.600.000,00. Disponível em:<http://www.sebrae.com.br/sites/PortalSebrae/artigos/entenda-asdiferencas-entre-microempresa-pequena-empresa-emei,03f5438af1c92410VgnVCM100000b272010aRCRD>. Acesso em: 29 de fevereiro de 2017.
} 
produzir a sua própria coleção, é apenas um dos exemplos, mencionados no capítulo anterior, de como se comportam.

A empresa que possui uma equipe interna de designers, sem laços afetivos, a coloca em segundo plano e todas as honras são destinadas ao familiar que assina pelas criações. Este comportamento sempre aconteceu e, segundo o relato dos designers contratados por essas empresas, não será mudado. Conforme nos mostram as entrevistas, estes designers sentem falta de um diálogo interno, aberto e objetivo com seus superiores; de terem esclarecidas as tarefas e obrigações a serem compridas em suas funções; como também, a definição de uma política de cargos e salários a ser implantada pelas empresas. Acreditam que esses seriam os primeiros passos para a melhoria das suas condições de trabalho, ultimamente aquém das expectativas do grupo, mas que ainda deseja e luta pelo reconhecimento de seus esforços.

Eventualmente algumas empresas possuem o hábito de contratar designers mediante acordo de exclusividade sobre a sua produção criativa. Com exigências que abrangem desde o sigilo de informações sobre peças e coleções em processo de execução, à posse de tudo aquilo que é produzido por eles durante o período de contratação. Através desta conduta essas empresas buscam algum tipo de proteção jurídica, priorizando assim a prevenção de problemas que possam vir a ter com os próprios designers ou com outras empresas do setor. Há casos, também, em que os designers respondem pelo ineditismo de suas criações, assumindo assim, via contrato, a responsabilidade, caso ocorra algum processo de plágio movido contra elas.

Falar sobre o assunto originalidade ou de criação de novas formas no campo joalheiro do Rio de Janeiro é um tema difícil, muito complexo e cheio de controvérsias. Quem entre os pares do campo do design nunca ouviu a afirmação de que tudo neste mundo tudo já foi criado? Ou simplesmente em design nada se cria tudo se copia? E que agora, só nos resta o trabalho de transformar ou reinventar o que já existe... O campo de design, em especial o de produto, muitas vezes se apropria desse comportamento para justificar as denominadas "novas" formas trabalhadas em objetos já existentes, aperfeiçoando algum detalhe e acreditando que estão gerando novas necessidades de consumo, enfim, que estão aplicando os princípios da economia criativa, aludido mais acima. Este trabalho não se pretendeu a questionar sobre a existência desse tema, ou mesmo medir o grau de 
originalidade das peças que são criadas, produzidas e comercializadas pelo setor joalheiro no Rio de Janeiro. O que estamos examinando é o fato de que as empresas, fabricantes e/ou comerciantes de joias, bijuterias ou folheados, solicitam o trabalho dos designers como um meio de obter criações inéditas para compor o seu catálogo de mercadorias e assim, se destacarem perante a concorrência e produzindo mais valia.

Os designers, quando contratados por essas firmas, buscam cumprir um cronograma de trabalho. O problema, no nosso modo de ver, é que há uma série de investimentos muito questionáveis ou discutíveis que são apresentados tal como o caso das economias criativas, soluções que se pretendem definitivas, mas que são de voo raso e péssima aterrisagem. Os que se apresentam para pensar os problemas do campo joalheiro desenvolvem pesquisas de tendência, de moda e de mercado, tendo como objetivo a criação de novos produtos, ou novas formas de produtos a serem lançados basicamente nas principais datas comemorativas e reconhecidas pelo comércio para o setor joalheiro como um dia em que é praticamente obrigatório oferecer presentes - Dias das Mães e Natal. Geralmente esses designers não possuem contato direto com outros departamentos, como por exemplo, com as oficinas e os profissionais envolvidos na produção das peças, ou com o marketing que elabora as campanhas e o material publicitário e uma boa medida seria em primeiro lugar fazer essa associação. Ocorre que os proprietários enxergam esses estudos e reflexões como uma ameaça de uma possível formação de comércio paralelo e concorrente. O feedback ${ }^{195}$ da equipe de vendas sobre a nova coleção, por exemplo, também é visto como argumento para dar margem a um pedido de aumento salarial. O sucesso das peças, e consequentemente o aumento no volume de vendas, será atribuído à sorte ou "obra do acaso" e não como um "bom trabalho" de uma equipe de trabalho incluindo aí os serviços de design. Enfim, o problema não é propriamente do campo do design ou dos designers, mas da forma passadista ou tradicionalista como os empresários gerenciam seus negócios.

Enquanto os gestores não perceberem que a troca de informações entre seus funcionários contribui para o aprimoramento do negócio, para a melhoria dos processos internos e do próprio produto, sua empresa continuará andando em círculos, fazendo as mesmas coisas de sempre. A insegurança em incentivar o

\footnotetext{
${ }^{195}$ Feedback - terno em inglês usado para definir o retorno das informações e dos resultados gerados a partir de alguma atividade, processo ou projeto.
} 
trabalho em equipe, no qual todos são importantes para o bom andamento do negócio, faz com que a probabilidade de apresentar um produto ou serviço "inovador" aos seus clientes, e ao setor joalheiro como um todo, seja praticamente nula e ineficaz. A própria equipe de vendas poderá ser capacitada a fornecer dados sobre os produtos e a identificar os desejos dos clientes e assim, contribuir para o planejamento e criação de novas linhas e coleções, como também, fornecendo elementos para campanhas publicitárias. Os designers e os profissionais envolvidos com a produção, trabalhando juntos no aprimoramento dos processos fabris, na implantação das novas tecnologias de modelagem virtual e prototipagem 3D, ou mesmo resgatando técnicas artesanais, que caíram em desuso, para serem trabalhadas sob uma nova perspectiva. Além disso, os profissionais envolvidos com a gestão de pessoas, a partir da interação com outros departamentos internos da empresa, poderão contribuir com dados para a criação de novos serviços, como um novo estilo de atendimento diferenciado e ainda não oferecido aos clientes.

Conforme informações abordadas no capítulo anterior, podemos destacar que fatores como: a escassa oferta de vagas e a baixa remuneração que é dada ao trabalho dos designers em geral, no estado do Rio de Janeiro, mas o design de joias em particular, fizeram como que os interessados em atuarem no segmento de joias, bijuterias, folheados ou biojoias buscassem pelo empreendedorismo individual como forma de iniciarem seus negócios. Isso também pode ser constatado com a mudança de cenário que, desde a década de 1990, vem sendo construído pelo setor joalheiro. A nova geração de profissionais e os antigos artesãos, que se mostraram interessados em acompanhar essas mudanças, sentiram a necessidade de adquirir algum tipo de formação profissional no setor e assim trabalhar com mais conhecimento de causa o objeto joia.

A demanda crescente por essa profissionalização colaborou para a criação e oferta de cursos de pós-graduação e graduação tecnóloga no campo. Os cursos livres e de menor duração, destinados ao aprendizado prático de técnicas de criação, desenho, fabricação artesanal e informatizada de peças, ou de classificação de gemas e outras matérias-primas também tiveram sua ascendência. Já em outra categoria, mais burocrática e/ou administrativa, temos os cursos destinados à gestão e formalização do negócio, capacitação de equipes de venda, precificação e organização de estoques, meios de 
comercialização e novos canais de divulgação das mercadorias, entre outros, oferecidos pelas associações e entidades privadas que atendem ao setor.

O interesse em profissionalizar e assim construir um novo cenário para setor joalheiro, foi positivo ao ponto de observarmos a quantidade de designers autônomos, com seus trabalhos autorais e/ou comerciais, que surgiram no mercado e conquistaram seus espaços. Por outro lado, a oferta de cursos, principalmente os de pequena duração, abriu espaço para os curiosos, que estavam dispostos a tentar a sorte investindo em algum segmento dentro do setor. A criação, ou talvez devêssemos falar apenas de produção ${ }^{196}$ e a comercialização de produtos foram as áreas mais exploradas por esses profissionais, que movidos por uma oportunidade não se sustentaram por muito tempo no mercado.

Com um olhar ousado e livre das amarras da tradição familiar hegemônica no campo, essa nova geração de empreendedores busca corajosamente unir forças ao se lançarem em projetos diferenciados, como por exemplo, o de uma loja multimarca de designers de joias. ${ }^{197}$ Esse conceito de negócio, já existente no mundo da moda, passou a ser explorado pelo setor joalheiro e apresenta resultados satisfatórios para seus integrantes. Estes participam em conjunto de todas as decisões estratégicas da empresa e também dividem os custos operacionais que envolvem o funcionamento de um ponto de venda. A presença em eventos e feiras ${ }^{198}$ que reúnem moda, arte, design, decoração e gastronomia, também é uma estratégia adotada pelos designers autônomos, que não possuem uma loja física, mas querem se aproximar do público carioca e de outros visitantes.

Outro ponto a ser destacado sobre os novos empreendedores é o desejo imoderado por novidades e novas tecnologias, mas que infelizmente estão muito atrasadas no nosso estado. A modelagem virtual, com o auxílio de softwares específicos que trabalham a construção das peças em três dimensões - altura, largura e profundidade -, possibilita a visualização do projeto de uma joia antes mesmo da sua execução. Através de uma imagem em perspectiva, que poderá ser renderizada, aplicando-se digitalmente a ela todas as características da peça real, o cliente será capaz de conhecer aproximadamente todos os detalhes de

\footnotetext{
${ }^{196}$ Nos parece que é problemático mencionar o termo criação, mas certamente produção de joias é um termo mais apropriado.

197 Joya, que reúne dez designers em sua loja, localizada na Galeria Forum em Ipanema.

${ }^{198}$ Babilônia Feira Hype, Circuito Moda Carioca, Armazém 4, O Cluster, O Mercado, Retoke, são alguns dos exemplos.
} 
sua joia e receber um orçamento mais preciso em relação a da quantidade de matéria-prima utilizada e/ou custos de sua fabricação.

A etapa da modelagem se completa com a impressão 3D ou prototipagem rápida dos modelos virtuais e assim, possibilita a sequência mais rápida do processo de produção. E, é neste exato momento que encontramos o primeiro gargalo e ser vencido em prol das novas tecnologias. Enquanto a primeira etapa poderá ser desenvolvida com o uso de uma versão não autorizada ${ }^{199}$ do Rhinoceros, em um computador que possua as configurações mínimas que comportem o software, por exemplo, a segunda etapa dependerá de máquinas específicas e de custo ainda elevado para a sua execução. Para dificultar, são poucos os locais no estado do Rio de Janeiro que oferecem o serviço de prototipagem rápida com qualidade, e nenhum deles disponibiliza, ou já pensou na possibilidade da criação de algum tipo de proteção para os arquivos recebidos, e assim, evitar a impressão da mesma peça para dois clientes diferentes que contratam esse serviço da sua empresa. Não exploramos em nossas reflexões as intensões desta prática, e se ela é lícita ou não. $O$ fato é que clientes perguntam sobre a existência de modelos prontos e próximos ao que estão procurando... E alguns designers, preocupados com isto, tentam se proteger enviando arquivos com partes de peças misturadas e desta forma dificultar a visualização completa do resultado final de suas criações. Talvez, se os envolvidos com o setor respeitassem corretamente os princípios éticos da profissão, não iriamos precisar mais nos preocupar com essas questões, pois a ética seria uma das premissas básicas praticadas por todos.

No Rio de Janeiro, o emprego adequado dessas novas tecnologias de criação e produção está bem longe de acontecer. Para essa possibilidade começar a ser pensada precisaríamos de um acréscimo significativo no número de empresas terceirizadas e prestadoras dos serviços de impressão 3D no estado. As empresas fundidoras também precisariam investir em tecnologia para acompanhar a evolução dos materiais em que são impressas as peças ${ }^{200}$, e continuarem atendendo a esse novo segmento. Quanto aos projetos modelados virtualmente, devem ser executados por profissionais com experiência na construção manual de peças em metal, e assim minimizar erros que só serão

\footnotetext{
${ }^{199}$ Versão "pirata" que pode ser adquirida sem a autorização da empresa detentora dos direitos de comercialização e divulgação do software.

${ }^{200}$ Atualmente no Rio de Janeiro as empresas só trabalham com as peças impressas em cera, pois utilizam dos mesmos equipamentos usados nos processos tradicionais. Não estão habilitadas para trabalhar com peças impressas em resinas termoplásticas e outros polímeros
} 
percebidos com a fabricação das peças. Esses profissionais podem ser: os próprios designers que criaram as peças, ou um projetista, de nível técnico, que vai executar o projeto da joia com o auxílio de um software 3D a partir de desenho que represente a ideia da joia criada por um designer ou outro profissional habilitado para a função.

Poderíamos sintetizar o problema afirmando que o campo joalheiro precisa se modernizar ou se industrializar e com isso entendemos que para exercer a função de projetista, o profissional deve dominar as ferramentas oferecidas pelos ambientes virtuais, interpretar e modelar em 3D as ideias, levando em consideração os resultados reais desejados. Podemos observar que este profissional, com a experiência promovida pelo tempo, se sente capacitado a criar também as suas próprias peças. Porém, a ausência de uma formação superior em design de produto, ou similar, e o desconhecimento de processos metodológicos empregados no desenvolvimento de novos projetos, fará com que suas peças acompanhem os estilos das marcas para quem ele trabalhou, exceto é claro, que além de projetista ele demonstre essa modalidade romântica e subjetiva que denominamos talento para a criação, noção essa que repudiamos por ser irracional e anticientífica, ainda que seja hegemônica. Enfim, somos contra essa noção, pois ela também é tradicional e passadista, não resolve nosso problema. Julgamos que o que é preciso é investir em novos processos industriais e na formação de técnicos habilitados nas novas tecnologias e não em gênios da arte ou do design. O nosso entendimento é que parte criativa virá por si mesma, ou como consequência da adoção desses novos processos produtivos, pois a criatividade não é uma pomba divina que pousa sobre a cabeça do criador, mas o resultado de esforços, disciplina e determinação.

A necessidade de o projeto virtual ser executado em perfeitas condições de fabricação também gera a demanda de cursos preparatórios específicos e que julgamos só deveriam ser oferecidos por profissionais que dominassem os dois universos: o real da ourivesaria, com o devido tirocínio da manipulação do metal, e o meio virtual, com conhecimentos dos softwares de modelagem 3D e as múltiplas possibilidades de aplicações de suas ferramentas, que também demandam um certo tirocínio. Enquanto isso não acontecer e os cursos forem oferecidos por tutores que não levam em consideração as especificidades da produção artesanal - o tirocínio de alguns anos de prática na lide com os materiais - do produto joia, o projeto executado virtualmente corre o risco de passar por correções após ser fundido, em sua fase de montagem. Também, de 
ter a sua execução inviabilizada, por ter ficado com uma espessura de chapa muito grossa, por exemplo, gerando uma peça mais encorpada e que vai consumir muita matéria-prima para sua fabricação e consequentemente ficando fora dos padrões de custos da empresa. Esse é um dos "enganos" mais comuns que pode acontecer.

Talvez a falta de interesse dos órgãos competentes, sejam eles governamentais ou dos pares do campo, em incentivar investimentos nessas novas tecnologias de criação e produção, seja uma forma de preservar o que os pares entendem por ser a integridade das empresas atuantes no setor e ao mesmo tempo, manter o círculo de trabalho formado por um grande número de profissionais autônomos, principalmente das etapas de produção, e que seriam os mais afetados diretamente pelos impactos dessas novas tecnologias. Essa conduta das oficinas afeta diretamente os designers que enxergam infinitas possibilidades de aplicações da modelagem virtual e da prototipagem rápida em suas criações. Pensando radicalmente sobre o assunto, o fato é que as peças podem ser trabalhadas em série, mantendo sempre o mesmo padrão e com maior precisão de detalhes, e nestes quesitos, a tecnologia é superior ao trabalho humano... Porém, ela ainda depende do humano para acontecer.

Durante o II Seminário de Atualização Tecnológica e o Setor de Joias e Bijuterias $^{201}$, realizado em outubro de 2015, um dos palestrantes convidados abriu a sua apresentação se questionado se estaria participando do $20^{\circ}$ encontro, e não o $2^{\circ}$, como havia sido anunciando. Esse comentário, tido como uma brincadeira para descontrair o público presente, que em sua maioria, formado por profissionais atuantes em diversos segmentos do mercado, nos faz pensar como o setor joalheiro no Rio de Janeiro está atrasado, ou mesmo parado no tempo, em relação às novas tecnologias de produção, criação, controle de qualidade, de estoque e uma infinidade de recursos que já são empregados em diversas indústrias do setor e pelo comércio de bens de consumo e serviços oferecidos no estado.

Os designers autônomos, que geralmente desempenham quase todas as funções dentro do próprio negócio, seriam talvez, os que tirassem o maior proveito desses recursos provenientes dessas tecnologias, se os seus custos não fossem tão elevados. Esses profissionais declararam que na verdade, gostariam mesmo é de se dedicar a maior parte do tempo à criação e ao

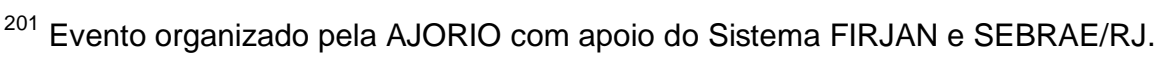


desenvolvimento de novos produtos, sem se preocuparem com custos e contas a pagar ou mesmo com a produção e comercialização das peças e toda a burocracia envolvida na negociação.

Sendo assim, percebemos que esses profissionais autônomos e ativos no setor, valorizam o design e o empregam como um fator diferenciador em seu trabalho, mesmo não tendo o tempo desejado para se empenharem nessa etapa. Esses profissionais se sentem motivados em fornecer novidades constantes aos seus clientes e não se preocupam muito com as cópias de suas criações, ao menos que elas aconteçam de forma explícita e comprometam a sua imagem. ${ }^{202}$ Acham que os meios legais de proteção não são eficientes, são caros e por isso não os utilizam. Alguns também consideram a cópia como um mecanismo de aceitação do mercado, porque uma vez copiado, significa que o seu design agradou ao ponto de chamar a atenção para uma prática da cópia indevida, mas que ainda é utilizada pelo setor.

Já as empresas contratantes no estado do Rio de Janeiro, envolvidas com a produção e/ou comercialização de mercadorias, que possuem equipes próprias de designers ou terceirizam a criação, admitem que o design de suas peças impacte diretamente no resultado final das suas vendas. E apesar disso, estas empresas remuneram mal os seus profissionais, que insatisfeitos, reclamam dos baixos salários. Os consumidores finais do setor, ou seja, o usuário de joias, folheados ou bijuterias, também valorizam as mercadorias com design, e segundo dados pesquisados ${ }^{203}$, estão dispostos a pagar mais caro por isso.

O design para o campo joalheiro é reconhecido como um agregador de valor percebido ${ }^{204}$, isto é, o que mencionamos mais acima, produtor de mais valia ou lucros nos objetos produzidos e comercializados pelo setor no Rio de Janeiro. Independente se é empregado apenas dentro de uma empresa ou praticado por um designer autônomo em suas peças, todos bebem da sua fonte para criarem seus produtos, divulgarem suas novidades e argumentarem suas vendas,

\footnotetext{
202 Em 2014 a marca de moda feminina FARM foi processada por plágio pelo designer Willian Farias. A empresa copiou uma de suas peças em ouro, fabricando-a em latão e expondo em suas vitrines com o título: Prata da Casa. Disponível em: < http://www.plagio.com.br/acusada-de-plagiogrife-farm-reconhece-erro-e-recolhe-colar-de-lojas/>. Acesso em: 26 de fevereiro de 2017.

${ }_{203}$ Dados sobre o comportamento das consumidoras no Relatório de Inteligência / Moda, 2017. SEBRAE. Disponível em: < https://www.sebraeinteligenciasetorial.com.br/produtos/relatorios-deinteligencia/acessorios-femininos:-um-mercado-de-

detalhes/58ac16bc37a6ad1800ab5000\#download >. Acesso em: 22 de fevereiro de 2017.

204 Valor percebido é uma prática utilizada por vários setores para precificar suas mercadorias levando em consideração suas qualidades e outros atributos que são valorizados/percebidos pelo cliente.
} 
portanto tudo indica que a percepção empírica dos pares do campo é legítima e não uma mera fantasia romântica, ou simples imaginação em relação à estética que mencionamos mais acima. Ter produtos criados por um designer ou ser o próprio a assinar pelas coleções é sinônimo de status, pois aos olhos dos consumidores isso significa que tais peças foram criadas por um profissional qualificado no assunto, mesmo que este não se sinta recompensado financeiramente por isso. Possivelmente trata-se da reprodução de um antigo valor cultural por parte da recepção, pois a joia ainda é vista como investimento pecuniário e ao mesmo tempo como cristalização de valores perenes que talvez nem existam mais, tal como o afeto ou ao amor que se dedica a uma pessoa. Em uma época onde as relações afetivas são tão precárias como a relações entre trabalhadores e patrões, é muito difícil aceitar a ideia de que um rapaz ao oferecer uma aliança de diamante para uma moça, esteja ofertando o seu amor sincero para todo sempre. Julgamos que outrora isso foi verdadeiro, mas nos dias de hoje trata-se de mito romântico e custa acreditar que um rapaz se sinta obrigado a comprar uma joia com um diamante, pequeno que seja, para simbolizar para sua amada que aquele sentimento é para sempre.

\section{2 \\ 0 estudo de caso}

Batizado como Projeto Cristal, o experimento realizado teve como proposta inicial a prática de uma conduta diferenciada e não usual de remuneração do trabalho de criação desenvolvido pelos designers autônomos para as empresas do campo joalheiro no Rio de Janeiro. Geralmente essa remuneração é feita por "criação", ou seja, o pagamento é efetuado por unidade de desenho, independentemente da existência de algum processo de pesquisa por trás de sua concepção. Não entraremos no mérito dos valores que são praticados pelo mercado, até porque não temos nenhum mecanismo ou mesmo uma simples tabela a ser consultada e que defina esses preços, aspecto esse que também julgamos precisar ser modernizado. O que podemos afirmar é a existência de uma hierarquia, na qual a peça principal recebe um valor superior ao das peças posteriormente criadas para compor um conjunto ou uma família. Algumas empresas também possuem o hábito de pedir por descontos, sugerindo lucro com a quantidade de desenhos comercializados. Sendo assim, para a realização 
desse projeto, quantidades de desenhos/criações não foram estipuladas e a remuneração ocorreu sobre um período de trabalho, pré-determinado em 30 dias - de 30/07/2016 a 28/07/2016.

O projeto contou com a participação de: i) uma empresa atuante no campo joalheiro do Rio de Janeiro, com expressiva participação no comércio nacional e internacional de gemas coradas brasileiras, brutas e lapidadas; ii) estudantes do curso superior em Design de Moda da Universidade Veiga de Almeida - Camila Câmara e Vera Schueler - uma recém-formada e a outra no último período da graduação, que tiveram um breve contato com os adornos pessoais em uma disciplina de projeto - Projeto de Adornos, e que mesmo sem possuírem conhecimentos sobre os processos que envolvem o desenvolvimento e fabricação de uma joia, nutriam curiosidade sobre o produto e se mostraram motivadas pelo desafio proposto no projeto.

A empresa selecionada, que por motivos éticos e profissionais terá a sua identidade preservada, atua no campo joalheiro comercializando gemas brutas e lapidadas, de diversas cores, formatos e tamanhos, para serem usadas na criação e montagem de colares, anéis, pulseiras e brincos. Peças prontas de bijuterias, folheados, acessórios de moda, como por exemplo, os cintos, e ainda, peças para uso esotérico e/ou decorativo, também são fornecidas por ela. Sua produção é terceirizada e conta com o trabalho (a parceria) de garimpeiros, lapidários, artesãos, designers e empresas prestadoras de serviços, como as transportadoras de mercadorias. Há três décadas atendendo ao consumidor nacional e internacional, desde os designers às empresas e profissionais autônomos que confeccionam e/ou comercializam suas próprias mercadorias com gemas, aos lojistas e pessoas físicas que revendem as bijuterias, folheados e os demais produtos acabados fornecidos pela empresa.

Totalizando 50 horas de trabalho, distribuídas em 10 encontros, com uma média de 5 horas diárias, o Projeto Cristal viabilizou o desenvolvimento e a criação de novos produtos para essa empresa, que não possui um departamento ou equipe de criação própria. Ao mesmo tempo, proporcionou às estudantes a vivência da prática de mercado, e todo o processo foi acompanhado por um designer especializado no assunto e com experiência na criação e produção artesanal de peças para o campo joalheiro nacional. A empresa escolhida, que aceitou 0 convite para participar da experiência, representa o perfil da grande maioria dos empregadores do campo, comércio e indústria, que atualmente e por algum 
motivo, financeiro ou mesmo estratégico, não possuem suas equipes de criação e optam por terceirizar essa etapa. Podemos observar que essa prática muitas vezes se reflete diretamente na apresentação de um produto, que por sua vez não se comunica com a filosofia da empresa que o comercializa, sendo baseado em um briefing voltado para uma oportunidade momentânea apontada no mercado, tal como foi mencionado mais acima em relação às datas comemorativas de feriados religiosos como o Natal ou naqueles dias em que culturalmente somos "obrigados" a presentear.

Seguindo as bases de uma metodologia projetual - problema/oportunidade, método e solução -, apresentados por BAXTER (2011, p. 37) e LÖBACH (2001, p. 142), e comumente utilizada para o desenvolvimento de projeto de produtos, as etapas percorridas pelo experimento foram organizadas e priorizadas de acordo com metas estabelecidas e prazos a serem cumprimentos, sendo elas: i) conhecer o cliente/a empresa, seus produtos e o problema a ser solucionado; ii) briefing do cliente; iii) definição de um cronograma e estratégias para o desenvolvimento do projeto; vi) seleção de matéria-prima comercializada pela empresa para o desenvolvimento do projeto; v) pesquisas de tendências de moda e de produtos similares comercializados por concorrentes no mercado; vi) visita à feira de setor; vii) desenvolvimento de ideias; viii) montagem de modelos; ix) confecção de planilhas de custo; $x$ ) ficha-técnica de produção.

A primeira etapa cumprida pelo projeto foi efetivada com a visitação às instalações da empresa e a apresentação dos produtos comercializados, abrangendo desde as gemas coradas brasileiras encontradas em seu estado natural, e não beneficiadas, às lapidadas. Estas classificadas como: i) roladas, no formato que se assemelha ao das pedras encontradas no leito dos rios; ii) cascalhos, que compõe o reaproveitamento do refugo da lapidação e apresenta forma e aspecto o qual foi batizado; iii) formatos geométricos, indicado para uso esotérico e decorativo, como os prismas, as esferas, as pastilhas e os pêndulos; vi) as contas, lisas ou facetadas, em diversos formatos como por exemplo: esfera, oval, gota, pastilha, coração, quadrado, cruz, entre outros, que são furadas e organizadas em fios, representam o grupo de mercadoria mais comercializado pela empresa. Além desses insumos, também são comercializados produtos acabados, e que apresentados durante a reunião com o cliente/gestor da empresa, seriam o foco principal do nosso trabalho. Esse encontro, que contou com a participação de funcionários do setor de vendas, foi discutido o briefing que nortearia o projeto. 
O briefing que reuniu todas as informações relevantes para a definição do escopo do projeto, contou também com a escolha do nome e o prazo de desenvolvimento do experimento. $O$ cliente apresentou como objetivo principal a criação de novos produtos com a utilização dos insumos por ele comercializados. Deixou claro que desejava produtos mais competitivos, principalmente em preço, e destinados ao público consumidor de faixa etária mais jovem - média dos 20 anos - e diferente do que estava acostumado a atender. A princípio, essas peças deveriam ser desenvolvidas pensando tanto no mercado nacional quanto no internacional, e também, na possibilidade de serem oferecidas, por intermédio de encomendas, aos revendedores/lojistas e diretamente, no varejo, ao consumidor final. As peças, julgadas interessantes pela equipe de vendas da empresa, e produzidas por concorrentes indiretos também foram apresentadas como forma de definir um conceito a ser usado como guia pelo projeto.

O passo seguinte se deu com a montagem de um cronograma de trabalho, e a definição das estratégias de atuação do projeto para atender ao briefing apresentado pelo cliente. Neste momento, ao consultar os registros feitos no decorrer da primeira reunião, o grupo sentiu a necessidade de estabelecer uma definição mais objetiva do problema apresentado pelo cliente. Verificou-se que o briefing apresentado transmitia claramente as dúvidas que a empresa internalizava em relação ao seu produto, bem como sua indecisão de qual mercado de atuação, nacional ou internacional, o nosso projeto começaria a explorar. A partir desse fato, podemos observar que nem sempre os clientes/as empresas que contratam os serviços de um designer sabem exatamente o que querem. E assim, gerando uma nova etapa, na qual o briefing foi destrinchado, interpretado com objetividade e posteriormente reapresentado para o aceite final do cliente. Um briefing incorreto impacta diretamente no produto, que por sua fez não será satisfatório, rotulando como ineficiente o trabalho do designer.

Sanadas as dúvidas e com os ajustes realizados no briefing, principalmente com a definição do público consumidor e abrangência de mercados, o projeto seguiu seu curso com a seleção de matéria-prima direcionada ao usuário jovem presente no mercado nacional. As gemas, fornecidas pela própria empresa para estudo das primeiras ideias, serviram também para a elaboração de alguns conceitos, de acordo com os objetivos apresentados pelo cliente, sendo eles: i) peças versáteis que pudessem ser usadas como colares ou, enroladas no pulso, como pulseiras; ii) peças como utilização de couro e linhas enceradas coloridas, 
proporcionando um "ar" mais descontraído para os jovens consumidores que adoram um adorno pessoal; ii) trabalhar a ideia de que os cristais transmitem energias positivas e conferem proteção contra mau-olhado; iv) peças que resgatassem os técnicas manuais, como o crochê, por exemplo; v) peças com novas lapidações de pedras e desenvolvidas exclusivamente para o projeto; vi) peças em prata com gemas e que possuam preços competitivos no mercado.

Na moda consumida por um público mais jovem e na faixa dos 20 anos, o "estilo hi-lo" (high-low ${ }^{205}$ ) foi o tema escolhido para trabalhar a coleção desenvolvida pelo projeto. A mistura de peças "descoladas" 206 e mais baratas com peças caras e de marcas famosas, em uma mesma produção de moda, ou ainda, masculino e feminino, alfaiataria e moda esportiva, por exemplo, traduzem o comportamento de consumo do nosso público. Mediante à temática e às necessidades desses consumidores, priorizamos o uso de materiais naturais como o couro e das gemas com coloração suave e/ou neutra.

Paralelamente a essa etapa, visitamos a FIBA ${ }^{207}$, feira de negócios do setor, que reuniu em um mesmo local os principais fabricantes de bijuterias e acessórios em prata e folheados do segmento nacional. O evento se mostrou uma ótima oportunidade para pesquisar os últimos lançamentos dos concorrentes cariocas, e de outros estados, que também empregam as gemas coloridas em suas peças de bijuterias e folheados. Durante a feira, da qual nosso cliente participou como expositor, observamos ao longo do dia os visitantes e/ou consumidores que circulavam pelos corredores. O foco principal foi no perfil do público a ser trabalhado e assim, examinando o comportamento dos consumidores mais jovens, reafirmamos alguns dos conceitos anteriormente formulados pelo grupo, como o uso de gemas de cores neutras e de fácil combinação com o vestuário. Este público buscou por marcas que apresentavam peças confeccionadas com pontas de cristais transparentes ou gemas lapidadas em formatos geométricos (Figura 13), com os pêndulos usados pelos esotéricos, anteriormente mencionados. As gemas incolores ou as que apresentavam um colorido suave, como um quartzo rosa ou um citrino de amarelado mais claro, também fizeram parte dessa lista de mercadorias.

\footnotetext{
${ }^{205}$ High-low - terno em inglês que significa: alto e baixo.

206 "Descoladas" é uma gíria usada para definir uma qualidade das pessoas articuladas e que interagem socialmente em qualquer situação. No caso dos objetos é usada para definir os que combinam com diferentes estilos de roupa.

${ }^{207}$ Edição realizada em 06 e 07 de junho de 2016. Ver tabela dos principais eventos, p.74-75.
} 

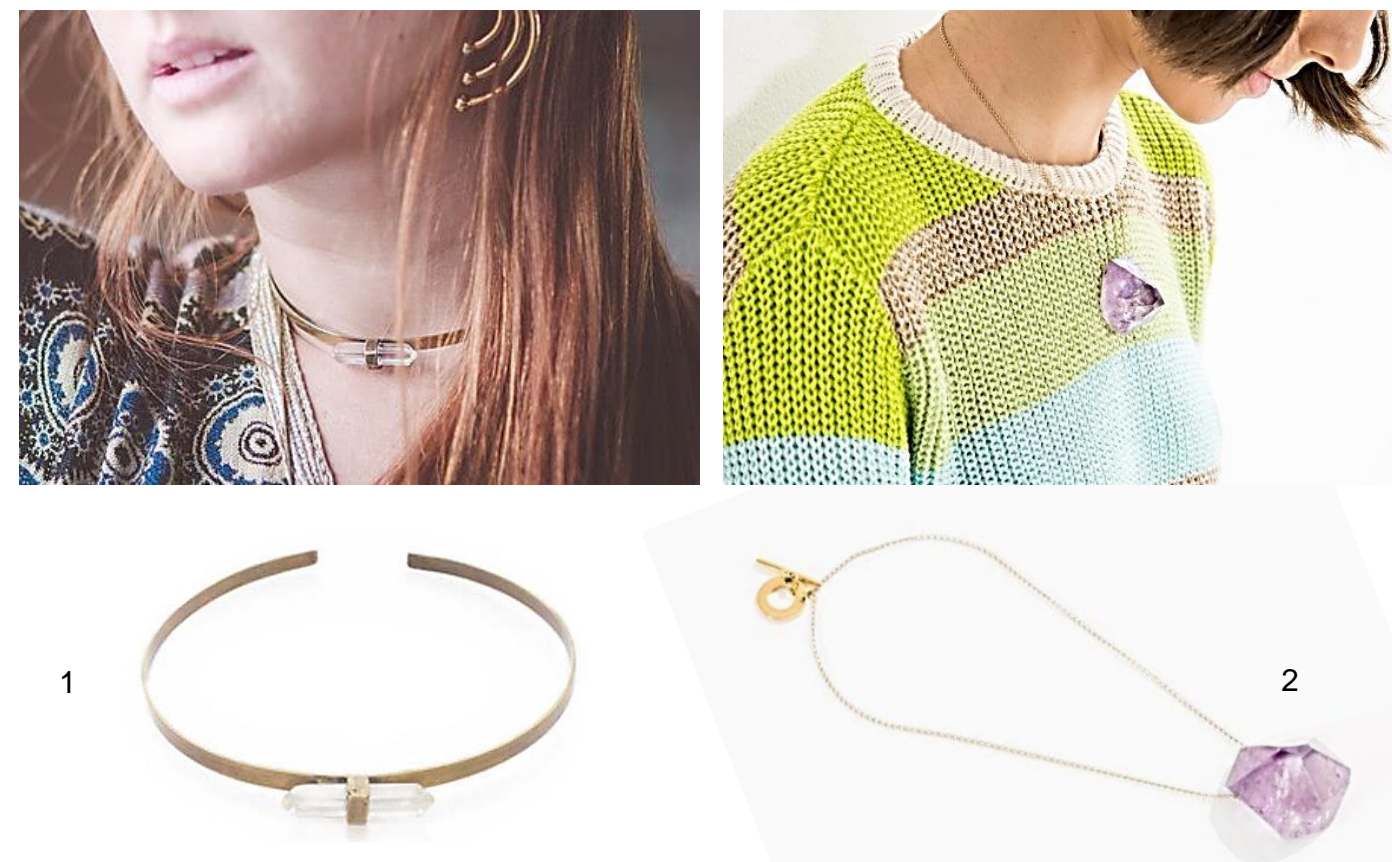

Figura 13 - Colares com cristal transparente e ametista.

1. Gargantilha em metal com banho de ouro velho e cristal, Flow; 2. Colar em metal com banho dourado e ametista facetada, FARM.

Através da ferramenta de cliente oculto, na qual simulamos uma intenção de compra nos estandes visitados pelo nosso público-alvo, presenciamos o interesse por bijuterias, principalmente colares e pulseiras, confeccionadas com couro e cristais de rocha. Bijuterias e folheados com correntes mais alongadas e colares montados com pérolas e fios de couro, também foram procurados, porém estes despertou o interesse de um público mais maduro - mulheres a cima da faixa etária dos 30 anos. Ao visitar os estandes, coletamos referências sobre as empresas e suas mercadorias a fim de melhorar o nosso entendimento sobre o mercado, dentro desse segmento específico do setor. Analisando os produtos similares encontrados, constatamos que eles se encaixavam com as descrições do briefing que havíamos recebido, ou seja, que o nosso cliente "deseja" o mesmo estilo de produto, e quer atingir o mesmo consumidor que a sua concorrência. E como fazer diferente algo que já está pronto? Esse foi um dos desafios para o projeto, além do custo final dos produtos e da resistência de certos mercados em oferecer mercadorias com gemas coradas brasileiras. 
Os primeiros registros, das primeiras ideias de colares que misturavam fios de couro com gemas coloridas que surgiram, foram representados em desenhos e logo o grupo sentiu a necessidade de mais um contato com o cliente para apresentar o andamento do projeto. Talvez isso tenha acontecido para reafirmar o briefing, os conceitos testados, e sanar toda e qualquer dúvida, leia-se: insegurança gerada pelo próprio cliente em relação às suas expectativas iniciais, haja vista o fato de nem mesmo ele saber muito bem o que queria. Neste encontro a equipe recebeu um novo pedido da empresa, e que alteraria alguns pontos já definidos no planejamento inicial. A criação passaria a acontecer simultaneamente à etapa de elaboração dos protótipos, dispensando a apresentação e aprovação inicial feita através de desenhos. Com este pedido, o gestor abdicou de uma das etapas iniciais e mais importantes que acontecem durante a criação de objetos produzidos com metais pelo setor, isto é, joias, folheados e bijuterias. Através dos primeiros desenhos, também chamados de croquis, as ideias são registradas sem a preocupação técnica com a produção. Aprovados, na etapa posterior são feitos os ajustes, incluindo as modificações quando solicitadas, refinamentos e detalhamentos da forma respeitando as dimensões reais da peça. Os detalhes de encaixes e os acabamentos, como fechos e pinos, recebem uma atenção especial neste momento.

O passo seguinte foi a elaboração de uma ficha-técnica de produção e que reunirá mais informações, como por exemplo: espessuras de chapas, medidas externas e internas em escala, processos empregados na fabricação, material principal, especificações de gemas ou outros materiais utilizados, identificação dos profissionais e suas respectivas funções nas diferentes etapas de produção, peso da peça, custo por operação, preço de custo final, entre outros fatores que irão variar de acordo com o tipo de peça fabricada. Sendo assim, destacamos a importância do conhecimento dos processos de produção pelos designers envolvidos nas etapas de criação dos produtos.

Com essa mudança, a estratégia inicial precisou ser reformulada. A etapa de criação com a elaboração de desenhos não foi adiante e a equipe partiu para o plano "B". Este trabalhou na criação de bijuterias, através da montagem de colares e pulseiras, com a utilização de matéria-prima já existente no mercado. Para isso, foi necessário a realização de um levantamento dos insumos - fios e fitas de couro, linhas enceradas, correntes outros acabamentos em metal, como: fechos, tubos, argolas e elementos em formatos variados - disponibilizados prontos pelas lojas de varejo que atendem ao segmento de bijuterias. Esses 
insumos deveriam atender a temática inicial, e ainda terem a sua utilização pensada de maneira inovadora na criação dos novos produtos definidos de modo impreciso pelo briefing. Através desse pedido, percebemos que a empresa enfrentaria dificuldades para a produção de peças em metal criadas com exclusividade para o projeto. E que, também, não tinha disponibilidade de tempo, nem mesmo possuía um profissional que ficasse responsável em acompanhar essa produção, inviabilizando assim a execução do que havia sido anteriormente planejado. Trabalhar a criação de produtos de design com os insumos existentes no mercado e que podem ser adquiridos por qualquer pessoa, está longe de ser o ideal, mas neste caso, foi um paliativo encontrado devido às condições de tempo impostas pelo experimento e também tratava-se de um exercício acadêmico.

Foram visitadas inúmeras lojas que comercializam insumos, dos mais variados tipos e materiais, destinados à montagem de bijuterias. Localizadas no SAARA, região conhecida pelo comércio popular, que engloba as ruas da Alfândega, Senhor dos Passos, Buenos Aires e suas adjacências, no Centro do Rio de Janeiro, foi o ponto de partida para a pesquisa e aquisição dos insumos utilizados para a montagem dos protótipos. A cada loja visitada, as peças que mostravam algum potencial eram avaliadas e, seguindo os conceitos e a temática definida para o projeto, em conjunto, o grupo decidia por sua aquisição. Sendo assim, ressaltamos que mesmo com a existência de um planejamento, o emprego da metodologia projetual para o desenvolvimento desses protótipos, a criação foi influenciada, e ao mesmo tempo, limitada, por esses elementos comprados.

Com todos os insumos reunidos, gemas coloridas brasileiras disponibilizadas pela empresa, mais os fios de couro de diferentes espessuras, correntes e acabamentos em metal que foram adquiridos no SAARA, chegava a hora de literalmente colocar a "mão na massa" e começar a produzir os protótipos. Porém, antes dessa etapa acontecer, o material foi organizado e classificado em uma planilha de acordo com os dados do fornecedor, nome e/ou código da peça, material, cor, quantidade por embalagem comercializada, valor total e valor por unidade. A partir de estudos preliminares, os insumos foram testados com as gemas e combinados entre si, e os resultados registrados sobre a forma de fotografias. Cada um dos integrantes foi responsável por uma parte desses os elementos, que quando necessário, foram trocados durante o processo de criação. A medida que uma nova peça era concebida, e antes de sua execução 
final, ela era apresentada aos outros membros do grupo, que podiam expressar alguma opinião, comparar com as fotos dos outros estudos registrados, ou simplesmente aprovarem sua produção.

O grupo se reuniu em um dos laboratórios multifuncionais, disponibilizado para os cursos de design, e com o auxílio de ferramentais apropriados para manipulação de peças metálicas, como: alicates, martelos, serras, brocas especiais e furadeira de bancada, iniciaram a montagem das peças. Essa, sem dúvida, foi a etapa mais prazerosa desenvolvida durante o projeto, que ao longo de quarto encontros, resultou na produção de 32 protótipos - 30 colares e 2 anéis, e mais uma dúzia de experimentos, seguindo o planejamento e o briefing previamente apresentado. Os protótipos criados foram motivo de satisfação e atenderam as expectativas criadas pelas próprias alunas, e que também, representavam o público consumidor que o cliente desejava alcançar com os novos produtos. Sendo assim, podemos considerar o comportamento das alunas como um dos indicadores de assertividade no projeto, pois elas próprias, jovens consumidoras interessadas em moda, estavam dispostas a comprar e divulgar as peças dessa nova coleção.

Após a elaboração das fichas-técnicas, com todas as informações reunidas para a reprodução das peças, foi chegada a hora da avaliação do cliente, momento de grande expectativa vivido pelas alunas, em relação a aceitação das peças. Definido o dia da entrega, o gestor da empresa reuniu sua equipe de vendas, para juntos analisarem o resultado do trabalho, que foi muito bem recebido e elogiado por todos. Algumas peças se destacaram por sua originalidade e outras pela facilidade de comercialização visualizada pelos vendedores. A equipe de vendas não se preocupou em eleger qual seria considerada como "a melhor" ou "a pior" peça dentro do conjunto apresentado. Todas, de certa forma, atendiam à diversidade de interesses da equipe. Outro ponto bastante elogiado foi a organização de como os dados técnicos foram apresentados. Todo o material estava relacionado em planilhas e fichas que acompanhavam imagens e descrição dos produtos. E, segundo uma das funcionárias, ao declarar que não estava acostumada a ver esse tipo de apresentação por parte dos prestadores de serviço terceirizados pela empresa, podemos concluir que, além da informalidade e falta de organização, que reforçam a constatação empírica de atraso em relação as modernas técnicas de produção, estes profissionais são autodidatas e, muito provavelmente, não possuem nenhuma formação relacionada com o campo do design ou afins. 
Quanto à remuneração, foi estabelecido no início do projeto um valor fixo pelo trabalho desenvolvido dentro de um período de 30 dias, independente da quantidade de peças criadas, que por sua fez, surpreendeu positivamente as partes envolvidas. Esse valor, acordado por todos os envolvidos, foi posteriormente convertido em mercadorias comercializadas pela empresa, e com isso, o projeto também encorajou as alunas que desenvolvessem suas próprias criações baseadas na experiência que estavam vivendo. Outro ponto importante, que deve ser mencionar, foi o trabalho em harmonia, desenvolvido em equipe e perfeitamente executado pelas alunas. Normalmente o trabalho de equipe não é valorizado pelos empregadores do campo, que incentivam a competição entre seus membros, e neste caso, entre os designers de uma mesma equipe na disputa pela invenção do produto mais vendável ou pela criação da maior quantidade de peças no menor tempo possível de trabalho, semelhante ao que acontece entre os praticantes de esportes individuais em busca de recordes a serem quebrados.

Após a entrega dos 32 protótipos e material de apoio que reunia as instruções de produção, passamos por um período de recesso escolar, durante o mês de agosto, ocasionado pela realização das Olimpíadas e Paraolimpíadas Rio 2016, no Rio de Janeiro. No mês de seguinte, as designers que participaram do projeto foram contatadas pelo gestor da empresa que manifestou o interesse em produzir as peças e testar a sua aceitação em duas feiras do setor. O Projeto Cristal, que a princípio foi estruturado como um experimento prático para avaliar o trabalhar de criação e desenvolvimento de novos produtos pelos designers, em relação à remuneração e um período de trabalho pré-definidos, sobre o enfoque da empresa, inicia um novo ciclo, a reprodução das peças criadas na primeira etapa.

Focada exclusivamente na fabricação e atendendo ao pedido da empresa, a segunda etapa do Projeto Cristal foi desenvolvida em um curto período de uma semana e meia. As alunas retornaram ao comércio para a compra dos insumos no atacado, e que quando esgotados nos estoques das lojas, geraram uma alternativa semelhante em forma e/ou material já usado nos protótipos, e principalmente dentro da mesma faixa de preço, para que não alterasse o custo final da mercadoria. Camila Câmara e Vera Schueler estrategicamente dividiram as peças de acordo com o grau de dificuldade e tipo de habilidade manual que cada uma deveria dominar para a sua execução, pois não haveria a interferência do profissional que as acompanhou no desenvolvimento da primeira etapa. Ele 
apenas conferiu a qualidade das peças reproduzidas, orientando em alguns os pontos de ajustes, antes da entrega ao cliente.

As 70 peças produzidas foram encaminhadas para as duas feiras de negócios em que a empresa mantém uma participação frequente, por considerar as mais importantes do setor: a FIBA, 23ª edição, em outubro de 2016, no Rio de Janeiro e a Bijoias ${ }^{208}, 75^{\text {a }}$ edição, em novembro, no Centro de Convenções Frei Caneca, em São Paulo. Logo na primeira feira $60 \%$ das peças foram vendidas e 0 restante consumido pelos clientes que visitaram o segundo evento, e elogiaram a mercadoria. A equipe de vendas da empresa não se mostrou surpresa com o resultado, que já era esperado, pois as peças criadas estavam seguindo as "tendências" da "moda do momento" e atendiam aos requisitos procurados pelos clientes da marca, que compram para consumo próprio ou revendem as mercadorias fornecidas.

Sobre o resultado geral alcançado pelo projeto, o gestor da empresa se mostrou satisfeito e disponível para novos desafios, porém, como todo bom comerciante, também quis fazer uma contraproposta: que as peças fossem criadas e produzidas pelo grupo de designers, pois o resultado foi muito positivo, e o pagamento só seria realizado a partir da venda direta ou da encomenda de uma quantidade maior de peças. E a empresa ainda se comprometeria com o fornecimento de parte dos insumos, as gemas, e com a divulgação e comercialização das mercadorias dentro da sua cartela de clientes. Notamos também que, mesmo tendo aceitado participar do projeto e aprovado o resultado, o gestor da empresa, de alguma forma, nos deixou transparecer que só arcaria com os custos do trabalho de um designer se este produzisse um resultado, que sua participação se traduzisse em "algo palpável" e passível de uma comercialização, que neste caso, foram os protótipos. Ou seja, a ideia desenvolvida sobre a forma de um desenho não é "válida", pois ainda precisaria ser produzida e caso contrário, arquivada, geraria custo, sem o retorno do investimento. Isso sem mencionar que a outra parte dos insumos, acabamentos em metal, fios de couros e outros materiais necessários, teriam, a princípio, seus custos bancados pelos próprios designers, tornando-os assim "sócios" desta parcela de produtos comercializados pela empresa.

Ainda sobre os resultados alcançados da primeira fase, podemos observar que ao dividir o valor recebido pela quantidade total de protótipos realizados,

\footnotetext{
${ }^{208}$ Feira de Acessórios, Bijuterias, Joias de Prata, de Aço e Folheados (sic).
} 
chegamos a um preço de $R \$ 62,50$ (sessenta e dois reais e cinquenta centavos) por exemplar criado e prototipado. E comparando a média de preços no qual essas peças foram expostas à venda, o lucro ou a produção de mais valia para a empresa se deu a partir da comercialização da segunda unidade. Assim, mais uma vez, podemos afirmar a importância do protótipo para esse cliente, que a partir da venda de apenas um exemplar, que pode ser o próprio protótipo, ele já tem coberto todos os custos com a contratação do designer, se esse no caso receber por mercadoria criada, conforme praticado pelo mercado.

Dividindo o valor unitário de cada peça pelo número de participantes do projeto, duas estudantes e um designer que conduziu o experimento, temos o valor de $\mathrm{R} \$ 20,83$ (vinte reais e oitenta e três centavos), que é considerado baixo para o mercado se comparado ao valor cobrado pela criação de outros produtos e/ou serviços que envolvem a participação de designers, com a elaboração de projetos. Se levado em consideração o valor da hora trabalhada, outra forma de precificação praticada pelo campo do design, o valor cai ainda mais, indo para $R \$ 13,33$ (treze reais e trinta e três centavos) a hora paga a cada participante, lembrando que cada produto contou com a contribuição de três agentes. Devido a isso, acreditamos, também, em um percentual de assertividade foi maior. Outra forma de demostrar os pontos positivos de um trabalho realizado em equipe.

O valor pago por hora/trabalho de criação apresentado acima é inferior, a grosso modo, aos valores cobrados pelos serviços dos fotógrafos de joias, profissionais que compõe o campo joalheiro e que contribuem para a exibição e divulgação das peças. Estes profissionais, especializados em registrar produtos com superfícies refletivas - polidas brilhantes e/ou facetadas -, e por isso de elevada complexidade de execução, também podem ter o valor do seu trabalho estimado pela quantidade de peças "clicadas" ou pelo tempo total gasto com o processo que vai demandar desde a organização do espaço/estúdio, escolha do ângulo certo do produto à adequação da luz e outros fatores envolvidos. Contudo, tanto a criação da peça quando a sua fotografia necessitam de processos específicos, cada qual em sua área, e se essa comparação for válida, ao mensurarmos o custo final de uma peça do Projeto Cristal, concluímos que o montante que seria pago pela fotografia da peça é superior ao valor pago pelo trabalho de criação. Outro ponto observado, em relação às quantias cobradas pelos registros fotográficos, é que muitos designers com a intenção de não aumentar os custos finas de suas peças se aventuram neste universo, 
produzindo seu próprio material, que, muitas vezes, resulta em fotografias de baixa qualidade e composição, desmerecendo o seu produto.

$\mathrm{Na}$ primeira fase do Projeto Cristal, a etapa de criação/desenvolvimento de protótipos foi considerada "uma das partes mais legais" pelos participantes, e que talvez, por visualizarem a possibilidade de futuros projetos pessoais, passaram também a ter interesse pela mercadoria comercializada pelo cliente. $E$ assim, a permuta do trabalho de criação por fios e gemas brutas foi considerada justa e convidativa ao momento, uma vez que esse foi o primeiro trabalho desenvolvido para a empresa, deixando claro que isso não poderia ser uma regra adotada para os próximos projetos. Outro ponto também mencionado pelas alunas, quando questionadas sobre a percepção que tiveram em relação a valorização do trabalho desenvolvido, foi o "convite" feito pelo gestor para participarem da divulgação e comercialização das peças durante os eventos de negócios os quais a empresa participa. Ou seja, além de disfarçarem o constrangimento gerado no momento, deduziram que o cliente espera que as funções do designer devem ir além dos limites de atuação da sua área, como por exemplo, trabalhar nos estandes com a venda dos produtos da empresa. Isso reflete a dura realidade encontrada no campo joalheiro e no mercado em geral, no qual os empregadores da indústria, do comércio ou prestadores de serviços, esperam que seus profissionais desempenhem papéis multifuncionais e assim, se mantenham empregados.

No caso da remuneração estabelecida na segunda fase, ao negociar o valor da mão de obra com o gestor, que mais uma fez solicitou a participação do responsável por sua equipe de vendas, percebemos que a precificação dos produtos deveria permanecer "interessante" ao cliente, mesmo após o somatório de todos os insumos e acrescido do lucro da empresa. Tendo como base os valores já adotados nos pagamentos praticados a outros profissionais que também terceirizam a montagem de peças para a mesma, o custo final da fabricação das nossas peças girou em torno de $R \$ 8,00$ (oito reais) para as classificadas como simples, a $\mathrm{R} \$ 20,00$ (vinte reais) para as mais complexas. Com isso, ficou claro que essa etapa não oferece atrativos financeiros para o designer, além da possibilidade de ser realizada por qualquer outro profissional que apresente certa destreza manual em manipular o material e atenção suficiente para seguir o projeto definido pelo protótipo. 
Independente de valores negociados, pagos e recebidos, justos ou mesmo desfavoráveis, afirmamos que o projeto exerceu de forma positiva a sua contribuição na vida profissional de duas estudantes de moda, que declararam terem vivido "uma experiência única" e que por isso, agora, se sentem mais confiantes a aceitarem propostas relacionadas ao campo joalheiro, que antes desconhecido, agora um novo caminho repleto de desafios. Quanto à empresa parceira no experimento, os resultados apresentados abriram possibilidades para outros projetos de design de produto e gráfico, como o desenvolvimento de embalagens, expositores, catálogos online e material a ser compartilhado nas redes sociais. O Projeto Cristal é apenas um exemplo de atuação de como o trabalho desenvolvido pelos designers pode ser empregado dentro do campo joalheiro existente no Rio de Janeiro. 


\section{Conclusão}

Ao longo destes dois últimos anos pude perceber o quanto romântica era a visão que construí sobre o campo joalheiro. Até então, em minha trajetória profissional sempre existiu a esperança de que um dia os profissionais atuantes no campo trabalhariam juntos e ergueriam bases sólidas para perpetuar o ofício da ourivesaria no Rio de Janeiro. Em meus "achismo" cheguei a acreditar que os responsáveis pelas desavenças existentes no campo estavam entre os que integravam o próprio campo. Atribui o problema às empresas familiares, nas quais seus donos/gestores não investiam de forma digna no trabalho dos designers para o desenvolvimento de suas coleções, e também, na qualidade da mão de obra e na carência de ética dos profissionais autônomos e envolvidos com as diversas etapas de fabricação das mercadorias que atendem ao campo joalheiro. Hoje percebo que vai além deles, englobando todos do campo... E como acontece entre as relações construídas pelos agentes de outros os campos, no campo joalheiro não poderia ser diferente. O campo joalheiro é compreendido como um espaço de divulgação e prestígio, no qual ser bem relacionado propicia alguns privilégios, é também, seguindo os ensinamentos de Bourdieu, um espaço onde as disputas se travam em competições disfarçadas, pois seus agentes mais privilegiados se valem da carência de oportunidade ou das dificuldades enfrentadas pelos menos abastados no campo para continuarem agindo em benefício próprio, criando obstáculos para que o campo se desenvolva e inibindo oportunidades que seriam ofertadas aos novos profissionais.

Através deste trabalho traçamos um panorama atual de como se apresenta o campo joalheiro no Rio de Janeiro que é formado pelas empresas fabricantes e comerciantes do campo, com destaque para as joalherias - Amsterdam Sauer e H.Stern - que construíram a história do setor; as organizações e associações envolvidas com os propósitos do campo; as instituições de ensino e todas as práticas envolvidas com a profissionalização e capacitação dos profissionais do campo, e completando com o grupo dos designers, contratados pelas empresas do campo ou empreendedores que por meio do desenvolvimento do seu trabalho 
são vistos como influenciadores ou criadores de tendências. Os designers empreendedores podem ser apontados como os mais novos agentes atuantes no campo e são os que mais desaprovam alguns vícios de contunda praticados pelos antigos profissionais, e que vêm sendo repetidos por gerações, como a cópia não autorizada das mercadorias, por exemplo. Percebemos que os profissionais que a praticam não temem por punições, e essa postura se deve ao descrédito dado às leis brasileiras que regem a proteção conferida pelos registros de Propriedade Industrial e Direito Autoral. Consideradas ineficazes, não são realizadas com a devida importância pelos agentes do campo. Porém, se esta atitude fosse revista pelos designers e pelas empresas, antes mesmo de serem lesados com a cópia de suas peças, e assim começassem a registrar e posteriormente divulgar que suas criações são protegidas, talvez, esta prática se tornasse uma conduta natural e com o passar do tempo, inibindo os profissionais mal-intencionados.

No final dos anos 1990, vivenciamos o fortalecimento da economia brasileira e com ela o campo joalheiro existente no Rio de Janeiro também prosperou, atraindo novos profissionais e interessados, e despertando para a necessidade da profissionalização do setor. Foi um período de crescimento único, que não mais se repetiu, no qual destacamos a parceria das instituições de ensino com os demais órgãos interessados - associações e institutos que atendem ao setor - em organizar e promover o ensino voltado para o campo joalheiro. Durante uma década os cursos atenderam a demanda dos novos profissionais e dos antigos atuantes no campo, que embarcaram nesta proposta em busca de novas oportunidades. Atualmente a situação que presenciamos em relação ao ensino superior e/ou profissionalizante oferecida para o campo é bem diferente. Turmas aguardam por novos alunos e o ensino está praticamente nas mãos dos cursos livres, sem certificação e oferecidos por designers de joias. Estes designers professores na grande maioria possuem formação superior na área do design joia ou produto - e/ou cursos complementares em ourivesaria e isto pode ser considerando um fator positivo para que eles continuem em funcionalmente, capacitando novos profissionais e atendendo os curiosos pelo campo. Os cursos livres funcionam utilizando o espaço dos atelieres dos próprios professores, e também representam uma fonte de renda complementar ao trabalho que desenvolvem como designers de joias.

Os processos que envolvem a criação e a produção das mercadorias - joias, folheados e bijuterias - e que também fazem parte do cenário construído pelo 
campo joalheiro, são registrados pela pesquisa. Mesmo com os ensinamentos das técnicas de produção ainda sendo transmitidos por conhecimento hereditário entre os membros de uma família, somado à presença dos cursos voltados para a prática da ourivesaria, estes meios não foram suficientes para manter vivas algumas das técnicas milenares desenvolvidas pelo ofício. A esmaltação* e a cinzelagem* são exemplos de técnicas que não foram extensamente usadas, caíram em desuso e não são mais oferecidas pelo campo no Rio de Janeiro. Outro ponto que deve ser registrado é a presença das novas tecnologias envolvidas na criação e produção de peças, com o auxílio de softwares especializados para a joalheria - Rhinoceros. Com esta tecnologia e joia não é mais simplesmente desenhada, e sim modelada em três dimensões e o seu modelo impresso em um material que poderá ir diretamente para a fundição, eliminado algumas etapas iniciais do seu processo de produção. No campo, principalmente os profissionais envolvidos com estas etapas sem sentem ameaçados de serem substituídos com o desenvolvimento e o emprego desta tecnologia. Contudo, isso está bem longe da acontecer, pelo menos no que diz respeito ao campo joalheiro do Rio de Janeiro. Das antigas técnicas de produção, que descartadas por não serem lucrativas, as mais modernas tecnologias de produção, e que requerem investimentos no setor para o seu desenvolvimento, ambas igualmente não despertam o interesse dos empresários cariocas e atuantes no campo. Essa postura só vem a confirmar o nosso atraso tecnológico e cultural dentro do setor, e também o nosso descaso com um ofício que já proporcionou muitos momentos de prosperidade para os envolvidos com o campo joalheiro do Rio de Janeiro.

Objetos de adorno pessoal, termo utilizado pela pesquisadora Irina Aragão dos Santos (2014) para definir o conjunto de peças decorativas e que são usadas tendo o corpo humano como o seu suporte principal, e que também passaram a ser adotadas pela pesquisa. Como exemplo destes objetos, comuns ao universo da joalheria, podemos citar os colares, anéis, brincos, tiaras, broches e etc. Estas peças podem ser produzidas em diversos materiais, dos mais nobres como o ouro e a parta, reconhecidos pela joalheria tradicional aos classificados como não convencionais, como a resina, a madeira e o plástico, e assim, serem divididas em categorias e nomeadas como: joias; folheados; bijuterias; biojoias e adornos de design. Esta última, e inédita, foi pensada a partir da necessidade de se encontrar uma categoria especial na qual se encaixasse a variedade de materiais que são empregados nas peças criadas pelos designers. Ainda dentro 
destas classificações praticadas pelo campo, identificamos uma que é equivocadamente usada por seus membros, as semijoias. "Semi" é um prefixo indicador de metade e somado a palavra joia, cria uma nova palavra que quer dizer: a metade de uma joia, e por isso não deveria ser usada. O consumidor que paga por uma peça folheada quer recebê-la inteira, e não a metade dela... Entendemos, porém que esta nomenclatura foi inventada para diferenciar os objetos folheados que são de boa qualidade e durável, dos que possuem baixa qualidade, no qual as peças predem rapidamente as camadas banhadas por materiais nobres revelando o seu material de origem.

Questões sobre a construção de um conceito para os objetos que representam o campo joalheiro do Rio de Janeiro abrem espaço para antigas discursões. Peças que apresentam o contorno literal os pontos turísticos da cidade, a topografia de suas montanhas e a beleza de suas praias, ou ainda os ícones que representam o estilo de vida dos moradores da Zona Sul da cidade e seus os constates sociais, entre outros, já tiveram suas formas exploradas e esgotadas pelos membros do campo joalheiro. Com base na análise destas peças identificamos que o uso das gemas coloridas brasileiras, tão desejadas por turistas em visita ao nosso estado, poderiam ser mais exploradas e assim trabalhadas como um diferencial em novos produtos. Em vista a este argumento, seria ainda necessário pensar em um "novo" conceito ou na possibilidade da existência de um "novo" arbitrário cultural a ser trabalhado pelos designers nos objetos que representariam o campo?

Uma das etapas mais relevantes da pesquisa foi a realização do mapeamento do cenário carioca atual sob a ótica dos designers. Através de entrevistas detectamos que questões antigas referentes à depreciação do trabalho desenvolvido pelos designers ainda permanecem, principalmente quando estes profissionais estão empregados em joalherias familiares, no qual o gosto do dono é um fator determinante, influenciando diretamente nos produtos apresentados pela empresa, sendo essa comerciante e/ou produtora do campo. Os designers deste grupo acreditam que quando estavam empregados nestas empresas "ganhavam menos do que mereciam" e sentiam falta de um plano de cargos e salários para assim planejarem suas carreiras. Sendo assim, podemos observar que não houve por parte dos empregadores ou mesmo perante as associações de classe e órgão competente, o interesse em promover essa prática dentro do setor, ficando os designers a mercê da generosidade de seus chefes. Entre os designers empreendedores, apesar da sobrecarga de trabalho e 
de terem que se dividir em inúmeras tarefas - criação, produção, marketing, venda, atendimento ao cliente e etc. - para cuidar sozinhos de suas empresas, legalizada ou não, este grupo se mostra realizado com suas conquistas, porém desejariam ter mais tempo para trambalharem em suas coleções. Quando questionados sobre a precificação de suas mercadorias, estes empreendedores declararam que seguem regras simples na quais contabilizam todos os gastos que envolvem o produto, mas quanto à hora de trabalho destinada a criação, não souberam precificar, justificando ser uma atividade prazerosa, e como cobrar por isso? Sendo assim, destacamos que o campo joalheiro ainda não possui uma tabela de preços que relacione hora/trabalho a ser praticada pelo campo, e que se essa um dia for criada e institucionalizada, ajudaria aos designers na formulação de seus orçamentos, tanto no que diz respeito as peças criadas para clientes particulares, como também dos desenhos que são desenvolvidos para empresas do campo.

A experiência prática realizada em parceria com uma empresa atuante no campo joalheiro do Rio de Janeiro, também serviu para comprovar que mesmo julgando importante e necessário a presença do designer na criação e desenvolvimento de novos produtos, os salários ainda não são justos, e os empregadores, sempre que podem, exploram o trabalho dos designers achando que eles podem e devem exercer outras funções. Este comportamento foi observado conforme o convite recebido pelos designers do projeto para participar da feira na qual as peças criadas seriam expostas e assim, "ajudar" na venda das mesmas. O Projeto Cristal além de proporcionar para a empresa selecionada a criação de uma nova coleção, a partir de suas necessidades, teve também como objetivo a apresentação do campo joalheiro para duas estudantes de moda e com isto, explorar novos horizontes dentro do campo de design, na criação e desenvolvendo de adornos pessoais. Esta experiência serve também de exemplo de como o campo do design se relaciona com o campo da joalheria, e como o trabalho dos designers pode ser empregado na geração de novos produtos. As alunas participantes, ao mesmo tempo em que se encantaram pela criação e desenvolvimento dos adornos pessoais, vivenciaram os problemas do meio e perceberem que este trabalho requer dedicação e conhecimentos específicos e que por isso, não deveria ser realizado por qualquer profissional. Logo, destacamos a importância dos cursos práticos que oferecem o exercício de construção de peças e a relevância do conhecimento do produto e para então desenvolver objetos passíveis de serem produzidos. 
Hoje, com um olhar mais amadurecido sobre o campo compreendo que meus sentimentos não passaram de uma utopia e que é preciso questionar, apontar o que não é certo, divulgar as descobertas, agir de forma ética e contribuir para as mudanças no campo. Palavras citadas por este trabalho, no qual declaram que o campo joalheiro trabalhou por durante muito tempo de "forma amadora e descompromissada" (MORAES, 2009), quase uma década depois, ainda fazem parte de nossa realidade... 


\section{Referências bibliográficas}

\section{Bibliografia principal}

BAUDRILLARD, Gean. O sistema dos objetos. São Paulo: Editora Perspectiva, 2000.

BAXTER, Mike. Projeto de Produto. São Paulo: Edgard Blucher Editora, 1998.

BOURDIEU, Pierre. A Economia das Trocas Simbólicas. $7^{a \underline{a}}$ ed. São Paulo: Perspectiva, 2013.

BOURDIEU, Pierre. O Senso Prático. 3ㅡ ed. Rio de Janeiro: Vozes, 2013.

CIPINIUK, Alberto. Design: o livro dos porquês. Rio de Janeiro: Editora PUCRio; São Paulo: Reflexão, 2014.

FORTY, Adrian. Objeto de desejo - design e sociedade desde 1750. São Paulo: Editora Cosac Naify, 2007.

HOBSBAWM, Eric J.; RANGER, Terence (org.). A Invenção das Tradições. 9a ed. São Paulo: Paz \& Terra, 2014.

LAVILLE, Christian; DIONNE, Jean. A Construção do Saber: Manual de metodologia da pesquisa em ciências humanas. Tradução de: Heloísa Monteiro e Francisco Settineri. Porto Alegre: Editora Artmed; Belo Horizonte: Editora UFMG, 1999.

LÖBACH, Bernd. Design Industrial. São Paulo: Editora Edgard Blücher, 2000.

PATACO, Vera Lucia Paracampos. Metodologia para trabalhos acadêmicos e normas de apresentação gráfica. / Vera Lucia Paracampos Pataco, Magda Maria Ventura, Érica dos Santos Resende. Rio de Janeiro: Editora Rio, 2004.

PHILLIPS, Peter L. Briefing: a gestão do projeto de design. São Paulo: Edgard Blucher, 2008.

SANTOS, Irina Aragão dos. Tramas de afeto e saudade: em busca de uma biografia dos objetos e práticas vitorianos no Brasil oitocentista. Rio de Janeiro: UFRJ, 2014. Tese (Doutorado) - IH Programa de Pós-Graduação em História Comparada - CFCH Instituto de História - UFRJ Centro de Filosofia e Ciências Humanas - Universidade Federal do Rio de Janeiro, Rio de Janeiro, 2014.

Joias de afeto: um catálogo de referências. Rio de Janeiro: UFRJ, 2009. Dissertação (Mestrado) - IH Programa de Pós-Graduação em História 
Comparada - CFCH Instituto de História - UFRJ Centro de Filosofia e Ciências Humanas - Universidade Federal do Rio de Janeiro, Rio de Janeiro, 2009.

Celtas e romanos: interações culturais através dos adornos pessoais. Rio de Janeiro: UFRJ, 2006. Monografia (Graduação) - UFRJ Departamento de História da Universidade Federal do Rio de Janeiro - Universidade Federal do Rio de Janeiro, Rio de Janeiro, 2006.

\section{Bibliografia complementar}

AJORIO - Associação dos Joalheiros e Relojoeiros do Rio. Disponível em: < http://www.sistemaajorio.com.br/site/ >. Acesso em: 15 de outubro de 2015.

Arco Ocupacional Joalheria: guia de estudos. Coordenação, Laboratório Trabalho \& Formação/ COPPE - UFRJ / elaboração, Associação Centro Design Rio - CDR. Brasília: Ministério do Trabalho e Emprego, 2006. Coleção ProJovem.

Bulgari. Disponível em: < https://www.bulgari.com/en-au/celebrating_explored >. Acesso em: 10 de março de 2016.

Cartier. Disponível em: < http://www.cartier.com.br/pt-br/maison/historia-eestorias/o-espirito-fundador-da-maison-cartier.html >. Acesso em: 10 de março de 2016.

Chaumet. Disponível em: < https://www.chaumet.com/our-maison >. Acesso em: 10 de março de 2016.

CNC - Confederação Nacional do Comércio de Bens, Serviços e Turismo. Disponível em: < http://www.cnc.org.br/cnc/sobre-cnc/historia >. Acesso em: 12 de novembro de 2015.

CODIN - Companhia de Desenvolvimento Industrial do Estado do Rio de Janeiro, responsável pela implantação e gestão dos distritos industriais no estado. Disponível em: $<$ http://www.codin.rj.gov.br/Paginas/Apoiolnvestidor/AlternativaLocalizacao/Altern ativasLocalizacao.aspx>. Acesso em: 08 de fevereiro de 2017.

FECOMÉRCIO - Federação do Comércio do Estado do Rio de Janeiro. Disponível em: < http://www.fecomerciorj.org.br/publique/cgi/cgilua.exe/sys/start.htm?UserActiveT emplate $=$ fecomercio $2008 \&$ sid $=77 \&$ infoid=865 $>$. Acesso em: 12 de novembro de 2015.

GIA - Gemological Institute of America. Cursos oferecidos pela instituição. Disponível em: < http:/www.gia.edu/gemeducation?gclid=CjwKEAiA7MWyBRDpi5TFqqmm6hMSJAD6GLeAV9Aia_ojtRfS sPMRuifQf7moGTmUPXg1ag5-78a-hhoCvYXw_wcB/ >. Acesso em: 22 de novembro de 2015. 
INETEP e os cursos oferecidos na modalidade EAD. Disponível em: < http://www.inetep.org.br/index.php/noticias/36-inscricoes-abertas-para-osegundo-curso-de-gemologia-ead >. Acesso em: 22 de novembro de 2015.

Joialerismo. Disponível em: < http://www.joialerismo.com/p/cursos-deourivesaria.html >. Acesso em: 20 de novembro de 2015.

Manual Técnico de Gemas. IBGM - Instituto Brasileiro de Gemas e Metais, DNPM. Brasília, 2005. Disponível em: < http://www.gemologiaibgm.com.br/laboratorio/wpcontent/uploads/2011/11/mtg_20051.pdf >. Acesso em: 30 de abril de 2016.

Manual de Exportações: guia de procedimentos para acesso a mercados internacionais para Bijuterias, folheados, gemas e joias. IBGM - Instituto Brasileiro de Gemas e Metais e Apex-Brasil - Agência Brasileira de Promoção de Exportação e Investimentos, 2016. Disponível em: < http://novo.infojoia.com.br/uploads/arquivos/file/2a1bb-ebook-final.pdf>. Acesso em: 26 de março de 2015.

Mapeamento da Indústria Criativa no Brasil. Sistema FIRJAN, 2016. Disponível em:

http://www.firjan.com.br/economiacriativa/download/mapeamento-industriacriativa-sistema-firjan-2016.pdf>. Acesso em: 12 de novembro de 2015.

Mapeamento da Indústria Criativa no Brasil. Joias, Bijuterias e Afins. Sistema FIRJAN, 2012. Disponível em: < http://www.firjan.com.br/lumis/portal/file/fileDownload.jsp?fileld=2C908A8A50019 C2B01501574A088159C\&inline=1 >. Acesso em: 15 de novembro de 2015.

Relatório de economia criativa 2010: economia criativa uma, opção de desenvolvimento. - Brasília: Secretaria da Economia Criativa/Minc; São Paulo: Itaú Cultural, 2012. 424 p. Disponível em: < http://unctad.org/pt/docs/ditctab20103_pt.pdf_>. Acesso em: 12 de novembro de 2015.

Relatório de Inteligência MODA - SEBRAE. Janeiro de 2017. Disponível em:<https://www.sebraeinteligenciasetorial.com.br/setores/moda/relatorios-deinteligencia >. Acesso em 20 de novembro de 2016.

SEMENSATO, Clarissa Alexandra Guajardo. Problematizações acerca do conceito "economia criativa" e da sua inserção na sociedade da informação. IV Seminário Internacional - Políticas Culturais. Fundação Casa Rui Barbosa, Rio de Janeiro, 2013. Disponível em: < http://culturadigital.br/politicaculturalcasaderuibarbosa/files/2013/11/ClarissaAlexandra-Guajardo-Semensato.pdf >. Acesso em 13 de dezembro de 2016.

Tiffany \& Co. $\quad$ Disponível em: < http://press.tiffany.com/ViewBackgrounder.aspx?backgrounderld=33 >. Acesso em: 10 de março de 2016. 
Van Cleef \& Arpels. Disponível em: < https://www.hautehorlogerie.org/en/brands/history/h/van-cleef-arpels >. Acesso em: 10 de março de 2016.

\section{Referências das imagens}

Figura 1 - llustração de colar em ouro branco com água-marinha (p.11). Marcello Barenghi. Drawing na aquamarine necklace (2013). Disponível em: < http://www.marcellobarenghi.com/2013/05/drawing-aquamarine-necklace.html >. Acesso em: 10 de dezembro de 2016.

Figura 2 - Esquema das etapas do processo de fundição de uma joia (p.35). Desenho elaborado pela própria autora, 2016.

Figura 3 - Exemplos de cravação (p.38). 1. Anel em ouro branco com gemas verdes (esmeralda, turmalina e quartzo verde) de diferentes tamanhos em cravação à inglesa, Antonio Bernardo. Disponível em: < http://www.antoniobernardo.com.br/metais-e-pedras/ >; 2. Anel em ouro branco com topázio azul em cravação meia-inglesa, Amsterdam Sauer. Obra de Candido Portinari isnpira joias Amsterdam Sauer. Disponível em: < http://www.infojoia.com.br/news_portal/noticia_13320 >; 3. Anel em ouro amarelo com gemas coloridas (berilo, citrino, rubi e turmalina rosa) em cravação com grifas, H.Stern, Disponível em: < http://www.hstern.com.br/joias/pproduto/A2BR171698/anel/dvf/anel-de-ouro-amarelo-18k-com-berilo,-citrino,rubi-e-turmalina-rosa---colecao-dvf >; 4. Anel em ouro branco com diamantes em cravação brunida, Antonio Bernardo. Disponível em: < http://www.antoniobernardo.com.br/catalogo/30-years-2011/?lang=en >; 5. Anel em ouro branco com brilhantes em cravação pavê, Joias 18 Karat. Disponível em: < http://www.18ktv.com.br/linha-diamante/anel-pave/>; 6. Cravação trilho. Anel em ouro amarelo com gemas coloridas (ametista, citrino, quartzo verde, safira, turmalina rosa e turmalina verde), H.Stern. Coleção Gemstones. Disponível em: < https://www.tradesy.com/accessories/hstern-hstern-rainbowcollection-gemstones-18k-yellow-gold-band-ring-20999550/ >. Acesso em: 15 de abril de 2016.

Figura 4 - Mapa do Campo Joalheiro do Rio de Janeiro (p.48). Diagrama elaborado pela autora, 2016 .

Figura 5 - Inspiração: Morro da Urca e o bondinho do Pão de Açúcar (p.51). 1. Pendente em prata Vanessa Robert. Disponível em: < http://www.vanessarobert.com.br/pingente-de-prata-pao-de-acucar >; 2. Anel em prata Pablo Lozano. Disponível em: < https://www.elo7.com.br/anel-pao-deacucar-em-prata/dp/5097B3 >; 3. Pendente em resina colorida Sobral. Disponível em: < https://www.bing.com/images/search?q=colar-pa\%cc\%83o-deac\%cc\%a7ucar-3743+sobral\&FORM=HDRSC2 >; 4. Pendente em ouro amarelo com brilhante Atelier Schiper. Disponível em:< http://www.atelierschiper.com.br/joias-detalhe.php?id=93 >; 5. Pendente em ouro amarelo Atelier Schiper. Disponível em: < http://www.atelierschiper.com.br/joias- 
detalhe.php?id=97 >; 6. Pendente em prata esmaltada Pandora. Disponível em: $<$ http://fashionando.com/pandora-cria-charm-para-homenagear-a-cidade-do-riode-janeiro/ >; 7. Pendente em prata Eduarda Rodini. Disponível em: < http://indesign-eduarda.blogspot.com.br/2013/08/brasilidade.html >; 8. Brincos em ouro amarelo Pablo Lozano. Disponível em: < http://www.pablolozano.com.br/pablo-lozano-brincos.html >. Acesso em: 01 de dezembro de 2016.

Figura 6 - Inspiração: Topografia do Rio de Janeiro (p.52). 1. Pulseira em prata Tatiana Bravo. Disponível em: < http://diariodorio.com/rio-de-janeiro-inspiracolecao-de-joias/ >; 2. Conjunto de anéis em prata Pablo Lozano. Disponível em: $<$ http://glamurama.uol.com.br/trabalhe-a-carioquice-com-os-aneis-de-prata-depablo-lozano/ >; 3. Conjunto de anéis em acrílico colorido verde, rosa, amarelo e azul, Tupinikingdom. Disponível em: < http://www.tupinikingdom.com.br/novidades/anel-topografico.html >; 4. Pendente em prata Uber47. Disponível em: < http://www.uber47.com.br/pingente-cristoredentor-de-prata-33/p >; 5. Pulseiras com banho de ouro amarelo e aplicação de esmalte colorido, Francesca Romana Diana. Disponível em: < http://www.carpedigi.com/pills/2014/francesca-romana-diana >; 6. Colar com banho de ouro amarelo e couro, Francesca Romana Diana. Disponível em: < https://www.francescaromanadiana.com/colares1/COLAR-SILHUETA-RIO >. Acesso em: 15 de dezembro de 2016.

Figura 7 - Inspiração: Cristo Redentor (p.53). 1. Pendente em prata Vanessa Robert. Disponível em: < http://www.vanessarobert.com.br/pingente-cristoredentor >; 2. Colar em prata Ateliê Carioca. Disponível em: < http://www.ateliecarioca.com/2011/09/cristo-redentor.html >; 3. Pendente em ouro amarelo Lulean Joias. Disponível em: < http://produto.mercadolivre.com.br/MLB-701481840-pingente-cristo-redentor-emouro-18k750_JM >; 4. Pendente em ouro amarelo Lafry. Disponível em: < http://lafry.com.br/ >; 5. Pendente em ouro amarelo Atelier Schiper. Disponível em: < http://www.atelierschiper.com.br/joias-detalhe.php?id=82\&produto=Cristo>; 6. Pendente em ouro amarelo Walmart, online. Disponível em: < https://querobarato.com.br/qb-pingente-cristo-redentor-em-ouro-18k-tgh0334-

walmart/pingente >; 7. Colar em ouro amarelo com brilhantes, vendedor não identificado, Mercado livre, online. Disponível em: < http://produto.mercadolivre.com.br/MLB-777116055-pingente-ouro-18k-cristoredentor-com-pedras-sedex-gratis-_JM >; 8. Pendente em ouro amarelo, Joias Gold. Disponível em: < http://produto.mercadolivre.com.br/MLB-710786125pingente-de-ouro-18k-cristo-redentor-pi17195-_JM >. Acesso em: 08 de dezembro de 2016.

Figura 8 - Inspiração: Lifestyle carioca (p.54). 1. Pendentes em ouro amarelo com esmalte e pulseiras de algodão encerado colorido com ponteiras de ouro, Lisht para a campanha: Rio, eu amo, eu cuido (2012). Disponível em: < http://www.joialerismo.com/2012/03/lisht-e-rio-eu-amo-eu-cuido.html >; 2. Pulseira e pendentes em prata com esmalte colorido, Linha Life, Vivara. Disponível em: < http://www.vivara.com.br/categoria/life-moments?Nrpp=450 >, < http://www.vivara.com.br/produto/pulseira-prata-com-corrente-de-seguranca-20- 
cm-life-moments/PL00015215 >, < http://www.vivara.com.br/produto/pingentecaipirinha-life-moments/EL00001309 >, < http://www.vivara.com.br/produto/pingente-drink-life/EL00046705 >, < http://www.vivara.com.br/vivara/produto/pingente-biquini-life/EL00048454 >, < http://www.vivara.com.br/vivara/produto/pingente-chinelo-preto-e-branco-lifemoments/EL00001697 >, < http://www.vivara.com.br/vivara/produto/pingentecadeira-de-praia-life-moments/EL00001300 >, < http://www.vivara.com.br/produto/pingente-oculos-life-moments/EL00001298 >. . Acesso em: 08 de dezembro de 2016.

Figura 9 - Inspiração: Pobreza e miséria, o outro lado da cidade (p.55). 1. Favela T-Shirt peça em madeira e ouro amarelo, vermelho, negro e branco, Camila Schmitt, joia finalista do concurso AuDITIONS Brasil 2015. Disponível em:< http://loja.camilaschmitt.com.br/camilaschmitt/premios/auditions-brasil-2015-recombinacoes/ >; 2. Coleção Crystals not Pistols, colares e anel com cápsulas de revólver e cristais brutos fluorita, ametista, citrino, pirita, ágata, quartzo incolor ou aqua aura - da australiana Mars, que veio à trabalho, se encantou e se mudou para o Rio de Janeiro, em parceria com Vinicius, morador da comunidade da Rocinha em São Conrado, Rio de Janeiro. Disponível em:< http://premiererangee.blogspot.com.br/2014/07/mars-da-favela-transformandocapsulas.html >. Acesso em: 02 de dezembro de 2016.

Figura 10 - Inspiração: Vida e obra de personalidades brasileiras (p.56). 1. Flor, desenho de Niemeyer. Disponível em: < http://www.consueloblog.com/wpcontent/uploads/2013/04/FLOR-desenho-de-Oscar-Niemeyer.jpg >; 2. Brincos em ouro amarelo e diamantes da Coleção Niemeyer - H.Stern. Disponível em: < http://www.consueloblog.com/wp-content/uploads/2013/04/FLOR-Brincos-de-

ouro-amarelo-texturizado-com-detalhes-de-diamantes.jpg >; 3. Anel em ouro amarelo da Coleção Portinari - Amsterdam Sauer. Disponível em: < http://www.infojoia.com.br/news_portal/noticia_13320 >; 4. Tela com representação de uma ciranda. Dança de Roda, de Portinari - junho 1966. Acervo digital Projeto Portinari. Disponível em: < http://www.elfikurten.com.br/2011/02/candido-portinari-mestres-da-pintura.html >. Acesso em: 01 de dezembro de 2016.

Figura 11 - Inspiração: Maracanã (p.56). 1. Anéis em ouro nobre com diamantes, nas versões em topázio azul, prasiolita e ametista, H.Stern. Disponível em: < http://www.gazetadopovo.com.br/viver-bem/moda-ebeleza/joalheria-brasileira-se-inspira-na-copa-e-lanca-anel-em-homenagem-aomaracana/ >; 2. Anel com material não identificado, mas que pela imagem aparenta ser em ouro branco ou prata, com banho de ródio negro na parte superior em que possui diamantes e esmeralda, Valéria Sá. Disponível em: < http://oglobo.globo.com/rio/design-rio-curvas-paisagens-da-cidade-do-rioinspiram-designers-de-joias-13631760 >. Acesso em: 15 de dezembro de 2016.

Figura 12 - Inspiração: Anéis que desempenham funções específicas (p.58). 1. SmartRing recebe notificações de textos, e-mails, mensagens e ainda acessa o Facebook e Twitter, MOTA. Disponível em: < https://www.techuntold.com/mota- 
smartring-features-release-date/ >; 2. Anel abridor de garrafas comercializado pelo site Aliexpress. Disponível em: < https://pt.aliexpress.com/item/Sale-2-PcsNew-Wholesale-Hot-Popular-Creative-Stainless-Steel-Finger-Ring-Ring-ShapeBeer-Bottle/32700727361.html?spm=2114.42010208.4.1.aHEulC >; 3. Anel Mr. Chapman's Secret, Antônio Bernardo. Disponível em: < http://www.infojoia.com.br/news_portal/noticia_8057 >. Acesso em: 15 de dezembro de 2016.

Figura 13 - Colares com cristal de quartzo transparente e ametista (p.124). 1. Gargantilha em metal com banho de ouro velho e cristal, Flow. Gargantilha 450xN flow. Disponível em: < http://www.flowacessorios.com.br/ >; 2. Colar em metal com banho dourado e ametista facetada, FARM. Disponível em: < http://www.farmrio.com.br/br/produto/colar-ametista-facetada/_A242846_0068.ptbr.farmrio >. Acesso em: 01 de dezembro de 2016.

\section{Referências da tabela}

Tabela 01 - Relação dos eventos comerciais que atendem ao campo joalheiro no Brasil. Tabela elaborada pela própria autora com base nas informações do Joia BR. Disponível em: < http://www.joiabr.com.br/feiras/feirasbr.html >. Acesso em: 15 de novembro de 2015. 


\section{Glossário}

Basse-taile - Método de esmaltação a quente no qual um desenho ou textura é gravado sobre a superfície metálica da peça e depois coberto por uma camada de esmalte transparente.

Cabochonné - Método de esmaltação a quente no qual a superfície da peça é cinzelada com pequenos relevos arredondados e sobre ela é aplicado o esmalte, que proporciona a ilusão da existência de gemas em formato cabochão.

Champlevê - Método de esmaltação a quente em que esmalte é aplicado nas áreas em rebaixo existentes na peça.

Cinzelado ou repuxo - Técnica artesanal que trabalha formas em volume e relevo sobre a superfície de chapas metálicas. O processo consiste em fixar uma chapa de metal sobre um suporte maleável, como por exemplo, um recipiente com piche, ou apoiar sobre uma almofada de areia, e golpear com o auxílio de ferramental apropriado - martelo e punções - o avesso da chapa até alcançar o desenho desejado.

Cloisonné - Método de esmaltação a quente no qual um desenho é formado por fios finos de metal, como molduras, bordas e limites que demarcam as áreas onde cada cor de esmalte será aplicada.

Embutido - Técnica artesanal que trabalha volume sobre a superfície de chapas metálicas. Com o auxílio de ferramental apropriado - martelo, embutidores bola e dado de bola - a chapa é golpeada sobre um gabarito que possui diferentes tamanhos de meias esferas, assumindo o seu formato.

Esmaltação - Procedimento decorativo de colorir a joia, também usado para proteger metais não nobres que oxidam rapidamente, que consiste em produzir uma camada vítrea sobre sua superfície metálica, ou preenchendo espaços vazados com a utilização de esmaltes, resinas e colorantes especiais.

Filigrana - Técnica artesanal que utiliza finos fios de metal, que podem ser lisos, torcidos, trançados, achatados ou não, e combinados entre si, para produzir 
joias, detalhes em peças ou ornamentos. Esse trabalho é semelhante a uma renda, porém executada em metal.

Fundição do lingote - Após o processo de separação e pesagem dos metais que irão compor a liga metálica, eles são depositados em um recipiente especial, chamado cadinho, que é aquecido com maçarico em um ambiente, uma capela, previamente preparado para este procedimento, na qual deve ser revestida como material refratário e possuir um sistema de exaustão de gases tóxicos. Quando a mistura de metais entra em ponto de fusão ela é derramada do cadinho sobre uma rilheira ou lingoteira, que são ferramentais apropriados para receber a liga fundida e assim, se obtém a forma inicial de lingote ou barra para o material.

Granulação - Técnica artesanal que antecede a filigrana, onde desenhos são formados a partir da fusão de micro esferas em metal que são organizadas sobre a superfície de uma peça metálica. Esta técnica foi muito usada em combinação com a filigrana para realçar detalhes de desenhos nas peças.

Grisaille - Método de esmaltação a quente no qual a pintura decorativa possui tons monocromáticos, degrade de cinza.

Laminação - Com o lingote de metal preparado, o passo seguinte consiste em transformá-lo em chapa, fios ou fitas de diversas espessuras conforme demanda o projeto da joia a ser executado. Nesta etapa será necessário o uso de um maquinário, manual ou elétrico, chamado de laminador. Ele possui dois cilindros de aço, alinhados um sobre o outro na posição vertical e por intermédio de uma engrenagem a distância entre eles pode ser regulada. $O$ metal passa entre os cilindros e passo a passo a distância entre eles é reduzida, comprimindo o metal até a espessura desejada. Similar às máquinas de massa caseira, na culinária.

Ligas metálicas - Na joalheria, a preparação das ligas metálicas consiste na fusão de dois ou mais tipos de metais, em diferentes proporções, no qual propriedades como: maleabilidade, resistência e ductilidade são manipuladas de acordo com as necessidades da peça a ser executada. O ouro puro, conforme é encontrado na natureza, por exemplo, possui um baixo grau de dureza e para que fique mais resistente e assim, possa ser usado na produção de joias, são acrescentados a ele outros metais. No Brasil, a liga utilizada é a $18 \mathrm{~K}$ ou 750 , o que significa que a cada $75 \%$ de ouro puro, $25 \%$ são de outros metais como a prata, o cobre, o níquel e o paládio. Além de realçar as qualidades e equilibrar as 
propriedades, a liga também pode ser usada para alterar a aparência do metal, que no caso do ouro, além do amarelo, também poderá ser produzido nas cores: branca, rosa, vermelha, azul, verde e com diferentes intensidades de coloração.

Limoges - Método de esmaltação a quente realizado em duas etapas distintas. Primeiramente a peça recebe uma camada uniforme de esmalte, geralmente em cor neutra, que servirá de fundo para o desenho. Após a queima do esmalte da base, a pintura decorativa, ainda em pó, é realizada sobre ela e a peça retorna ao forno para sua queima final.

Lixamento - Desgastar ou raspar o metal com o auxílio de uma lixa. O lixamento é uma etapa fundamental para se obter um bom acabamento final na joia. Deve-se começar com uma lixa mais grossa e ir gradativamente diminuindo a granulação até a mais fina, onde a superfície da peça não apresente mais nenhum arranhão e tenha a aparência de polida, porém sem brilho.

Plique-à-jour - Método de esmaltação a quente no qual o esmalte é aplicado em espaços vazados e sem fundo da peça, e seu resultado final se assemelha aos vitrais, porém em menor dimensão.

Polimento - O polimento é a etapa final de acabamento da joia. Ele confere brilho a superfície de metal que anteriormente foi lixada. Utiliza-se um maquinário específico, chamado politriz, dois tipos de pasta de polir e escovas, sendo a primeira mais abrasiva e a segunda mais macia.

Ródio - Metal que confere a cor prateada e brilhante às peças banhadas com ele. Pela joalheria o banho de ródio é usado com frequência no acabamento das peças confeccionadas em ouro branco, pois esse metal em sua origem possui uma aparência acinzentada.

Soldagem - A soldagem é um processo que consiste em unir partes de metal formando uma única peça. Na joalheria essa união deve ser imperceptível depois da joia finalizada e a realização desse processo vai requerer o uso de um ferramental apropriado como: maçarico a gás ou gás/oxigênio; pinças, telas e tijolos refratários para apoio das peças; solda (metal com ponto de fusão inferior ao das peças unidas); fluxo para conduzir a solda; composições químicas como o hidrogenocarbonato de sódio; ácidos para decapagem (limpeza) do metal.

Tratamentos químicos - Alguns tratamentos químicos são praticados ao longo do processo de fabricação das joias, como por exemplo, os que utilizam ácidos 
para refinar os metais, testar o seu teor ou mesmo retirar as impurezas da superfície na peça depois de um processo de solda, como a decapagem. Existem também os banhos de metais como: o ródio, o ouro amarelo e a prata, que são utilizados para dar acabamento, minimizar manchas, realçar o brilho ou mesmo alterar a aparência da própria peça. O ouro branco possui um aspecto acinzentado e para que as joias produzidas com ele fiquem com uma coloração mais prateada e brilhante, todas recebem um banho de ródio na última etapa de seu processo de fabricação.

Tratamentos térmicos - Durantes as etapas de transformação do metal, como laminação, trefilação e moldagem, por exemplo, será necessário o seu recozimento (aquecer e depois resfriar o metal em temperatura ambiente) para que se recondicione, recuperando qualidades de maciez, ductilidade e tenacidade, facilitando o manuseio e evitando defeitos e rachaduras ao longo da sua transformação. Já em outro estágio, com o objetivo de se obter uma maior dureza, aplicasse uma têmpera, onde o metal é aquecido e resfriado rapidamente.

Trefilação - A trefilação é um processo mecânico que usa a força de tração para produzir fios e charneiras (tubos) de diversos formatos e espessuras. Com o auxílio de uma matriz, chamada de fieira, e um alicate de pressão, o metal é introduzido e puxado por um orifício, com entrada maior mais que se estreita reduzindo o diâmetro do material e aumentando seu comprimento. 


\section{Anexos}

\section{Perguntas - Grupo A}

Critérios de escolha dos entrevistados: designers empregados ou que já trabalharam em alguma joalheria que produz sua própria mercadoria ou fabricante de joias, folheados ou bijuterias no estado do Rio de Janeiro, com tempo de atuação maior ou igual há cinco anos e formação superior em design de produto ou área similar.

1. Nome do designer entrevistado:

2. Formação/Instituição e ano de conclusão: (Incluir os cursos da área de joalheria ou os que contribuíram de alguma forma para o desenvolvimento de seu trabalho no campo).

3. Como teve conhecimento do setor joalheiro? (Algum familiar trabalha no setor, descobriu sozinho, por acaso ou por curiosidade durante um curso, viagem, visitando uma exposição ou outros).

4. Qual o nome da empresa (joalheria) que trabalha ou trabalhou?

5. Poderia descreveria o(s) tipo(s) de produto(s) desenvolvido(s) pela empresa que você trabalha ou trabalhou?

6. Que características a empresa busca ou buscava expressar com seus produtos? E como são ou eram interpretados pela equipe de criação?

7. Há quanto tempo trabalha na empresa ou qual foi o período que trabalhou?

8. Começou em qual departamento? Qual o seu cargo?

9. Sempre trabalhou neste departamento ou e foi promovido? Qual motivo?

10. Quantas pessoas trabalham ou trabalhavam com você no departamento de design? Você conhece ou conhecia a formação dessas pessoas? Se a resposta for "sim", qual a formação?

11. Essa formação contribui ou contribuiu para o trabalho desenvolvido?

12. Qual é ou era seu papel dentro dessa equipe?

13. Vocês trabalham ou trabalhavam em parceria com outro(s) departamento(s)?

14. Como é ou como era desenvolvido o seu trabalho no departamento de design? (Alguma metodologia adotada?)

15. Além da criação você desempenha ou desempenhava mais alguma função?

16. Como analisa ou analisaria o seu próprio trabalho, como designer, dentro da estrutura da empresa? 
17. Você acha ou achava que a empresa percebia/valorizava o papel do designer dentro da sua estrutura?

18. Você recebe ou já percebeu algum tipo de reconhecimento pelo seu trabalho?

19. Já enfrentou alguma resistência para desenvolver o seu trabalho?

20. Sobre a remuneração, ela é ou foi satisfatória?

21. Você desenvolve ou já desenvolveu alguma produção paralela ao trabalho na empresa? Criação autoral ou mesmo freelance para outra marca ou cliente particular...

22. Como percebe o produto que é desenvolvido pelo do setor carioca? Alguma característica/conceito chama a sua atenção?

\section{Perguntas - Grupo B}

Critérios de escolha dos entrevistados: designers empreendedores que possuem pelo menos um ponto de venda físico (loja física) no estado do Rio de Janeiro, e designers empreendedores que desenvolvem um trabalho autoral e que não possuem um ponto de venda físico, mas comercializam suas peças via sites de comércio eletrônico ou durante eventos e feiras sazonais do setor.

1. Nome do designer entrevistado:

2. Formação/Instituição e ano de conclusão: (Incluir os cursos da área de joalheria ou os que contribuíram de alguma forma para o desenvolvimento de seu trabalho no campo).

3. Como teve conhecimento do setor joalheiro? (Algum familiar trabalha no setor, descobriu sozinho, por acaso ou por curiosidade durante um curso, viagem, visitando uma exposição ou outros).

4. Há quanto tempo trabalha no setor joalheiro? (O que fazia antes de ser um empreendedor?).

5. Qual o nome da sua empresa/marca?

6. Há quanto tempo possui a marca?

7. Se tiver loja física, onde fica?

8. Site, qual o endereço eletrônico?

9. Qual o(s) tipo(s) de produto(s) é desenvolvido(s) pela sua marca?

10. Quais as características mais importantes que busca expressar em seus produtos?

11. Quantas pessoas trabalham na sua empresa? (Uma estimativa e incluir os prestadores de serviço, caso trabalhe com algum).

12. Qual é o seu cargo?

13. Como você divide o seu tempo e qual etapa tem a maior prioridade? (Criação; produção; vendas; administração do negócio; eventos; marketing; relacionamento com o cliente e outros). 
14. Quanto tempo da sua semana de trabalho você dedica a criação de seus produtos?

E à venda? E à administração do negócio?

15. Como você precifica o seu produto?

(Gastos com a produção, matéria-prima, embalagem e quais outros fatores?).

16. Como é o seu processo de criação e desenvolvimento de produtos?

(Usa alguma metodologia projetual?).

17. Com que frequência você lança novas peças / linhas / coleções?

18. Tem uma ideia de quantos modelos produziu até hoje? Faz banco de dados das criações?

19. Como você percebe o seu próprio papel, como designer, dentro da estrutura da sua empresa?

20. Como você acha que as pessoas que trabalham com você (incluir os profissionais terceirizados) percebem o papel desempenhando pelo designer no campo joalheiro?

21. Você acha que seus clientes percebem a importância do papel/trabalho do designer? Como?

22. Você se sente realizado? Sente falta de alguma coisa? O que, por exemplo?

23. Para abrir o seu negócio você buscou ajuda em alguma instituição ou com algum familiar/amigo experiente?

24. Você faz registro das suas criações? Que recurso adota para proteção das suas criações?

25. Como percebe o produto que é desenvolvido pelo do setor carioca? Alguma característica/conceito chama a sua atenção?

\section{Perguntas - Grupo C}

Critérios de escolha dos entrevistados: profissionais responsáveis pela equipe de criação/design das empresas que praticam a venda ao cliente final/varejo, e/ou das empresas produtoras de joias, folheados e bijuterias, com pontos de venda ou escritórios localizados no estado do Rio de Janeiro e que começaram suas atividades antes ou durante a década de 1990.

1. Nome da empresa (joalheria ou fabricante):

2. Tempo de vida da empresa:

3. Nome do entrevistado, cargo e qual a sua formação?

4. Há quanto tempo trabalha na empresa?

5. Existe departamento de criação/design na sua empresa?

6. Trabalha nele? Ou em algum departamento próximo a ele? Qual? 
7. Como ele é composto o departamento de criação/design da sua empresa? Por quantas pessoas e qual a formação de seus membros?

(Caso desconheça a formação da sua equipe, perguntar se julga necessário ter uma formação superior ou técnica para exercer a função de designer na sua empresa).

8. Tem conhecimento de como foi ou participou do processo para selecionar esses profissionais?

9. O que é indispensável na formação ou no conhecimento desse profissional para trabalhar com a criação dos produtos da sua empresa?

10. Em média, quanto tempo de trabalho/experiência, tem o profissional mais antigo e o mais novo do departamento?

11. De que forma a empresa valoriza o trabalho desses profissionais?

12. Você acha que esses profissionais se sentem valorizados e realizados?

13. Poderia descrever o(s) tipo(s) de produto(s) desenvolvido(s) pela empresa que você trabalha?

14. Que características a empresa busca expressar em seus produtos? E como as expressa na criação?

15. A equipe de designers participa de alguma decisão estratégica antes do desenvolvimento de produtos?

16. Você saberia descrever como é realizado o processo de criação de uma coleção, linha ou de peças isoladas?

17. Com que frequência são lançados novos produtos?

18. Faz banco de dados das criações?

19. A empresa faz registro das suas criações? Que recurso adota para proteção das suas criações?

20. Os designers participam ou já participaram de algum treinamento interno? Quais?

21. Os designers oferecem algum treinamento para equipe de vendas no lançamento dos produtos? (Apresentação do tema trabalhado na coleção e etc.)

22. Como percebe o produto que é desenvolvido e comercializado pelo do setor joalheiro carioca? Alguma característica/conceito chama a sua atenção? 